\title{
Orígenes, formación y testamento del escultor renacentista Arnaut Spierinck, o Arnao de Bruselas
}

\author{
Origins, training and testament of the Renaissance sculptor Arnaut \\ Spierinck, or Arnao de Bruselas
}

\author{
Aurelio Á. Barrón García \\ Universidad de Cantabria \\ Departamento de Historia moderna y contemporánea \\ Facultad de Filosofía y Letras. Edificio Interfacultativo \\ Avda. de los Castros, 52. 39005 - Santander \\ barrona@unican.es \\ ORCID: https://orcid.org/ 0000-0002-7608-5923 \\ Fecha de envío: 2/09/2019 Aceptado: 21/10/2019
}

Referencia: Santander. Estudios de Patrimonio, 2 (2019), pp. 65-120

DOI: https://doi.org/10.22429/Euc2019.sep.02.02

ISSN 2605-4450 (ed. impresa) / ISSN 2605-5317 (digital)

Este trabajo se enmarca en el Proyecto de investigación I+D del Ministerio de Economía, Industria y Competitividad HAR2016-77254-P

Resumen: El hallazgo del testamento del escultor renacentista Arnao de Bruselas permite saber que se llamaba Arnaut Spierinck y que tuvo un hermano Gil Spierinck que posiblemente se corresponda con el escultor y pintor que trabajó en Aldenarda de 1523 a 1536, sobre todo en la obra del ayuntamiento. En este último año Arnao aparece en la documentación de Zaragoza al ingresar en el taller de Damián Forment. Se aportan también algunos datos sobre el retablo mayor de Santa María de Palacio en Logroño, obra maestra de Arnao, y de otros retablos en los que intervino el escultor en Nalda -junto con Andrés de Araoz-, Torrecilla sobre Alesanco, Aldeanueva de Ebro y Tómalos en Torrecilla de Cameros, contratado por el pintor Juan de Rojas.

Palabras clave: Arnao de Bruselas; Arnaut Spierinck; Gilles Spierinck; Pauwels van der Schelden; Aldenarda; Audenarda; Escultura renacentista; Logroño; Zaragoza.

Abstract: The testament of the Renaissance sculptor Arnao of Brussels allows us to know that his name was Arnaut Spierinck and that he had a brother-Gil Spierinckthat possibly is the sculptor and painter who worked in Oudenaarde from 1523 to 1536 , especially in the Town Hall. In this last year Arnao appears in one document in Zaragoza when joining the workshop of Damián Forment. This article also studies some new data about the altarpiece of Santa María de Palacio in Logroño, masterpiece of Arnao, and other altarpieces in Nalda - carved together with Andrés de Araoz-, Torrecilla sobre Alesanco, Aldeanueva de Ebro and Tómalos in Torrecilla de Cameros, hired by the painter Juan de Rojas.

Keywords: Arnaut Spierinck; Gilles Spierinck; Gillis Spierinck; Pauwels van der Schelden; Audenarde; Oudenaarde; Renaissance sculpture; Logroño; Zaragoza. 
Arnao de Bruselas murió en Logroño a finales de 1564 o en los primeros días de 1565, poco después de modificar su testamento con un codicilo el día 22 de octubre ${ }^{1}$. Entonces sustituyó a Juan Jiménez de Cabredo por Agustín Pérez como cabezalero testamentario. A su mujer, Mariana, la mantuvo en esta condición, pero la reemplazó como tutora de su hijo menor de edad, Cebrián, por el mismo Agustín. En este acto mencionó que previamente había otorgado testamento ante el escribano Rodrigo de Abecia, cuyos protocolos no se han conservado.

Sin embargo, se incorporó copia del testamento en una demanda del tutor y curador de su heredero contra los mayordomos de la logroñesa iglesia de Santa María de Palacio que llegó, en segunda instancia, a la sala de apelaciones del arzobispado de Zaragoza del que dependía jerárquicamente el obispado de Calahorra-La Calzada antes de que se constituyera el arzobispado de Burgos y se le adscribieran como sufragáneos los obispados de Calahorra-La Calzada y Pamplona. El testamento lo había otorgado tres días antes del codicilo, el 19 de octubre. Arnao había enfermado durante el brote de peste que padeció Logroño a finales del verano de $1564^{2}$. Varios testigos de la demanda así lo declararon: que había fallecido durante la peste del verano de 1564, aunque hemos visto que seguía vivo a finales de octubre y aún el 20 de noviembre, fecha en la que los mayordomos de Santa María de Palacio hicieron un memorial de lo que adeudaban a $\mathrm{Arnao}^{3}$. El 16 de febrero de 1565 Agustín Pérez acudió con Cebrián de Bruselas ante el teniente de corregidor de Logroño para pedir confirmación de la tutoría y curaduría del pequeño. Este tipo de acto solía producirse poco después del fallecimiento del padre del menor, aunque cabe la posibilidad de que esperara a la muerte de Mariana, la madre .

1 RAMÍREZ MARTÍNEZ, José Manuel, La evolución del retablo en La Rioja. Retablos mayores, Logroño, Obispado de Calahorra, La Calzada y Logroño, 2009, p. 19 del CD, doc. 1.

2 Archivo Diocesano de Zaragoza (ADZ), Apelaciones, C. 210.8.

3 "A maese Arnao del retablo [...] 210795 maravedis"; ÁLVAREZ CLAVIJO, Mำ Teresa, Las artes en la iglesia Imperial de Santa María de Palacio de Logroño (siglos XII al XVII), Logroño, Instituto de Estudios Riojanos (IER), 1995, p. 223, doc. 23. Los mayordomos debían tener noticia de la enfermedad de Arnao y de su mal estado de salud ya que pusieron este revelador título a la "Memoria de lo que oy 20 de noviembre de 1564 se halla que debe la Yglesia de plazos pasados y por venir, fuera de salarios ordinarios, para que se provea y quando se pague no haya error de ello". Uno de los sacerdotes de la iglesia era hermano de Agustín Pérez.

4 ADZ, Apelaciones, C. 210.8. Agustín Pérez se presentó ante Álvaro Ortiz, teniente de corregidor de Logroño, y comunicó que Arnao le había dejado la tutela y curaduría de su único hijo, Cebrián. Visto que el menor parecía tener 5 o 6 años, el teniente de corregidor lo confirmó como tutor y curador tras jurar una administración fiel de los bienes del menor, que mantendría libro de cuentas y proseguiría sus pleitos y causas. Como Cebrián era rico -"regalado"-, con una hacienda de más de 2000 ducados, permitió al tutor y curador un gasto de alimentos de medio real diario. 


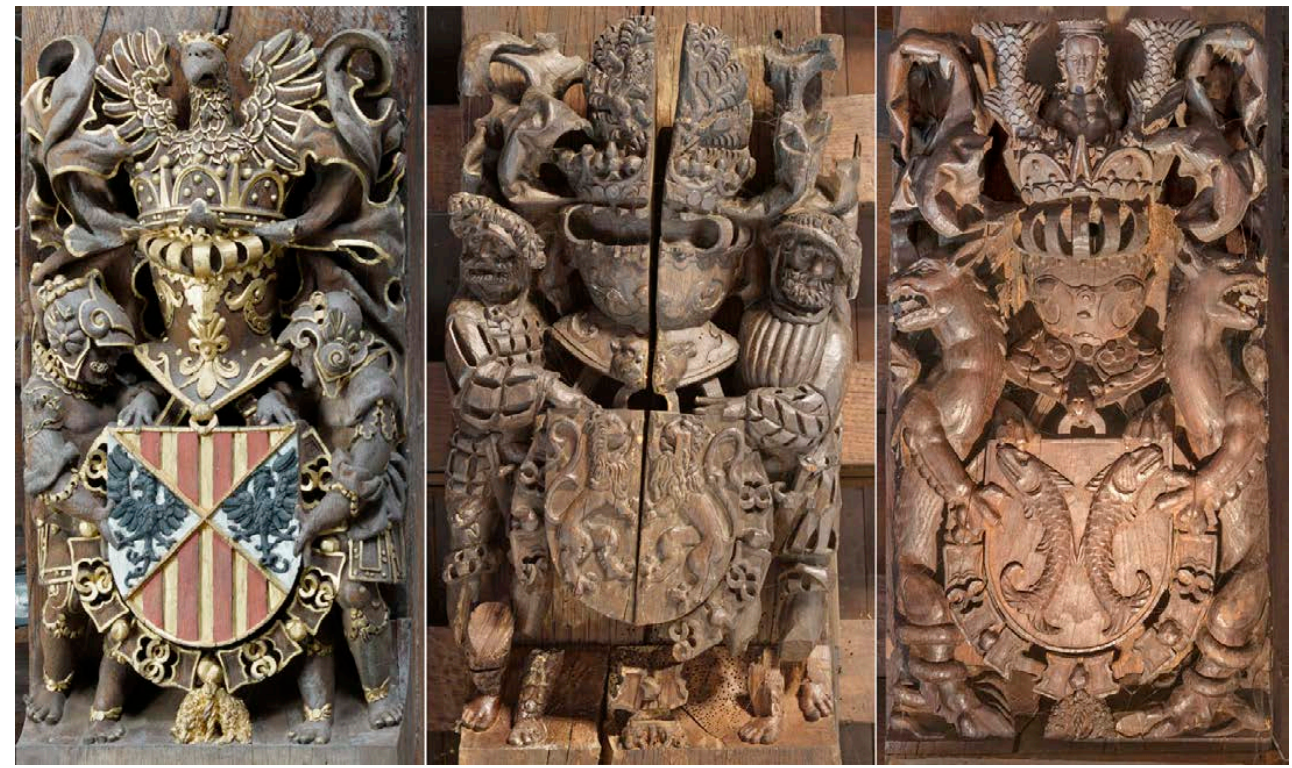

Fig. 1. Escudos de armas de Sicilia, Güeldres y Ferrette. Gillis Spierinck. 1528. Volkszaal y segundo piso del ayuntamiento de Aldenarda (Flandes, Bélgica)

Uno de los aspectos más interesantes del testamento es que mencionó el nombre y el apellido de su padre y de uno de sus hermanos, por lo que se puede intentar establecer relación con los artistas que permanecieron en Países Bajos. Como se sabe, era muy frecuente que los artistas venidos del Norte de Europa modificaran sus apellidos en España y resulta imposible, en la mayor parte de los casos, establecer relaciones estilísticas concretas. Seguramente observaron que los españoles tenían dificultades de transcripción de su fonética y la mayor parte adoptó el lugar o país de procedencia: Flamenco, de Flandes, Picardo, de Amberes, de Bolduque, de Cambray, de Bruselas... Hubo excepciones. El bretón Juan Guas transliteró en castellano su apellido neerlandés -Was- y así evitó cualquier problema de identificación de su firma ante los escribanos del reino. El caso más conocido en el territorio del obispado de Calahorra-La Calzada es el de Guyot de Beaugrant, que mantuvo el nombre y el apellido firmando con mucha claridad dentro de una cartela. En Zaragoza, el 10 de septiembre de 1536, en el primer acto notarial conocido Spierinck fue presentado como "Arnaut de Bruselles, natural de la ciudad de Bruselles de la tierra de Brabant de Flandes" ${ }^{\prime \prime}$. La documentación posterior lo nombró siempre como Arnao de Bruselas.

5 MORTE GARCÍA, Carmen y AZPILICUETA, Miguel, “Arnaut de Bruselas en el taller del escultor Damián Forment", Boletín del Museo e Instituto Camón Aznar, 35 (1989), p. 68; MORTE GARCÍA, Carmen, Damián Forment, escultor del Renacimiento, Zaragoza, Caja Inmaculada, 2009, Apéndice documental, pp. 435-436 doc. 407. 
Conviene también recordar que en este acto declaró que no sabía firmar, de modo que vino a España con una preparación práctica, pero sin demasiada instrucción. Muchos años después, en el pleito sobre el retablo mayor de Santa María de Palacio, Agustín Pérez argumentó que no sabía escribir. Si damos por buena esta declaración no habría aprendido nunca, aunque Criado Mainar transcribió un documento autógrafo de Arnao de Bruselas fechado en junio de $1558^{6}$.

Hemos visto que, al redactar el testamento y el codicilo, Arnao estaba enfermo y, como debía temer que también murieran su esposa y su hijo, se acordó de sus parientes. Escultor magníficamente bien dotado y emprendedor, había amasado una considerable fortuna que se cifró en más de 2000 ducados. Había de estar orgulloso del éxito logrado y quiso que su familia lo supiera y se beneficiara, aunque se deduce del testamento que no tenía noticias familiares probablemente desde los años de su llegada a España. En Logroño fue propietario de una huerta, una casa y un amplio taller que años después adquirió Juan Fernández de Vallejo ${ }^{7}$. Legó una considerable cantidad de dinero a un compatriota -Juan Flamenco- que era zapatero de Santo Domingo de la Calzada, pero en el caso de que su hijo Cebrián muriese "antes que yo o despues menor de edad" le impuso la obligación de buscar y avisar "a mys dehudos para que bengan a heredar my haçienda y para que sepa los que a de llamar digo que my padre se deçia Tosan Espirin vecino de Bruselas y un hermano que se dize Gil Espirin". El texto confirma que, como había declarado en Zaragoza en 1536, era originario de Bruselas. De otra cláusula testamentaria se deduce que, desde que llegara a España, no había mantenido contacto con su familia, pues desconocía si habían nacido otros hermanos con posterioridad a su establecimiento. Así, fuera de las mandas ordenadas, declaró heredero universal

"en todos mys bienes restantes a Çibrian my hijo / y si el dicho my hijo fallesçiere menor de hedad de poder testar mando que mys bienes bengan al dicho my padre o hermanos o hermanas que paresçieren y fincaren ser vibos vecinos de Bruselas como se contiene en el capitulo e manda del dicho Juan Flamenco y si faltaren padre o hermanos benga a los parientes mas propincos".

6 CRIADO MAINAR, Jesús, Las artes plásticas del Segundo Renacimiento en Aragón. Pintura y escultura 1540-1580, Tarazona, Centro de Estudios Turiasonenses, 1996, p. 737. Se trata de cuatro albaranes aparentemente autógrafos y firmados por Arnao -como Bruselas o Aro Bruselas- de junio a diciembre de 1558. Son de letra cursiva bien elaborada y habría que comprobar si, como veremos que sucedió en Logroño, fueron escritos enteramente por el mayordomo de la seo. Agradezco al profesor Criado Mainar la copia que me ha proporcionado de los cuatro recibís a cuenta de la obra del trascoro.

7 BARRÓN GARCÍA, Aurelio Á., “Juan Fernández de Vallejo y el taller de Arnao de Bruselas", Boletín del Seminario de Estudios de Arte y Arqueología arte (BSAAarte), 79 (2013), pp. 35-58. 
El apellido Spirin se ha mantenido hasta nuestros días en Bélgica, pero son más habituales otras formas: Spierinck, Spierinckx, Spierincks, Spirinck, Spieringh, Spierinx, Spirinc... El hermano citado se puede identificar con Gilles o Gillis Spierinck que está documentado, entre 1523 y 1536, como escultor y pintor en obras del ayuntamiento de Aldenarda o Audenarda (Audenarde/Oudenaarde) y en un retablo de la iglesia de Nokere, localidad cercana a la ciudad anterior (Fig. 1). Es posible que su padre también se dedicara a alguno de los oficios de tratamiento de la madera. Tosan ha de ser la forma castellanizada de Toussaint. Pronunciado en francés por Arnao, el escribano hubo de transcribirlo conforme a su fonética, o mejor, según lo entendió. Se puede plantear como hipótesis que Arnao hubo de formarse en el taller familiar, o a la vera de su hermano. Las obras del ayuntamiento de Aldenar$\mathrm{da}$, donde Gillis Spierinck tuvo un relativo protagonismo, finalizaron en el verano de 1536. Puede ser significativo que el 10 de septiembre de ese mismo año Arnaut de Bruselles, entrara en el taller zaragozano de Damián Forment. Al llegar era seguramente un virtuoso oficial, pero en España perfeccionó su estilo, adoptó por completo las formas del Renacimiento y acabó siendo uno de los más extraordinarios escultores de su tiempo.

\section{Un Primer Spierinck en España}

Años antes de que Arnao firmara un contrato de colaboración con Damián Forment, había llegado otro imaginero de apellido Spirin: Girart Spirinch. Dado que en Países Bajos fue muy frecuente que los oficios se mantuvieran por generaciones no se puede descartar -ni tampoco establecer vínculo alguno- que el imaginero Spirinch perteneciera al mismo tronco familiar que Arnao, de la generación del padre o del abuelo de éste.

Girart o Gilart Spirinch o Spirich/Espirich, es mencionado en la documentación como Gerard, Gelart, "Girardum Spirin, ymaginarium; "magistrum Girardum, alamanum"; Gerardum, alamanum ymaginarium", "Girardo Spirinch, ymaginerio"; "Giraldo Spirinch, ymaginerio"; "Geraldus Sperinch, alemmannus ymaginarius"; "Mestre Girart, ymaginayre", Garau Spirinch y Gilart Espiriuqt que pudiera ser la forma más cercana al apellido si en el documento escribieron Espirinqt. Las diversas grafías señaladas parece que se corresponden con un mismo imaginero, aunque se han manifestado ciertas dudas sobre si todas las menciones en Cataluña a mestre Girart se refieren a Girart Spirinch ${ }^{8}$.

8 YEGUAS I GASSÓ, Joan, L'escultura a Catalunya entre 1490 i 1575. De la tradició medieval a la difusió i consolidació de les formes "a la romana", Barcelona, Universitat de Barcelona, 2001 pp. 81-84; JARDÍ ANGUERA, Montserrat, Mestres entalladors a Barcelona durant la segona meitat del segle XV i primer quart del segle XVI: de la tradició germánica a la producció local, Barcelona, 
Está documentado en Barcelona desde diciembre de 1508 hasta su fallecimiento ocurrido poco antes del 30 de junio de $1522^{9}$ y fue uno de los más importantes imagineros que trabajaron en Cataluña en las primeras décadas del siglo XVI. El 13 de diciembre de 1508, junto con los carpinteros gerundenses Bernat Casals y Pedro Robán, seguramente el castellano Pedro Robredo, contrató la imagen titular del retablo de San Andrés de Palomar, obra que los carpinteros tenían comprometido realizar desde junio. En 1510 Girart Johan -identificado con Spirinch por Madurell- debía tallar las figuras de San Pedro y San Pablo para Santa María del Pino de Barcelona. En agosto del mismo año capituló la imagen titular del retablo de San Cugat del Vallés y dos columnas. De 1513 a 1515 trabajó en los órganos y en la trona de Santa María del Mar de Barcelona. Es posible que acompañara al pintor napolitano Nicolau de Credença desde 1509 y es seguro que colaboraron en 1514 y 1515: Spirinch se encargó de la estructura y las imágenes del retablo de San Miguel de Montserrat y de la figura de San Bartolomé en el retablo mayor de Bellpuig. En 1515 entraron como aprendices en su obrador Gaspar Granollers y Johannes Just, originario de Euzon en el Imperio alemán -tal vez Eupen en Limburgo, ahora provincia de Lieja-. En 1517 tomó otro aprendiz: Joan Benet, francés de 18 años natural de Tours que Yeguas identifica con Joan de Tours o Joan de Torres $^{10}$, escultor que colaboró más tarde con Martín Díez de Liatzasolo; fue uno de los tasadores del retablo de Poblet dirigido por Damián Forment ${ }^{11}$.

Universidad de Barcelona, Tesis doctoral, 2006, pp. 272-274; http://diposit.ub.edu/dspace/bitstream/2445/35592/4/03.MJA_CAP_3.pdf.

9 Los datos básicos de la biografía de Spirinch los trazó, MADURELL MARIMÓN, José Ma "Escultores renacentistas en Cataluña", Anales y Boletín de los Museos de Arte de Barcelona, V, 3-4 (1947), pp. 238-242, 278, 303-305. También, BASSEGODA Y AMIGÓ, Bonaventura, Santa María de la Mar: monografía histórico-artística, Barcelona, Fills de J. Thomas, 1925, I, pp. 262-263, 411413; AINAUD, J[oan] y VERRIÉ, F[rederic] P[au], "El retablo del altar mayor del Monasterio de San Cugat del Vallés y su historia", Anales y Boletín de los Museos de Arte de Barcelona, I, 1 (1941), p. 35 y docs. XIII-XIX en pp. 49-51; MADURELL MARIMÓN, José Má, "Pedro Nunyes y Enrique Fernandes, pintores de retablos. (Notas para la historia de la pintura catalana de la primera mitad del siglo XVI)", Anales y Boletín de los Museos de Arte de Barcelona, I, 3 (1943), p. 88, nota 141; YEGUAS I GASSÓ, Joan, L'escultura a Catalunya..., pp. 81-84; YEGUAS I GASSÓ, Joan, “Obres al convent de Bellpuig (1507-1535)", Urtx: revista cultural de l'Urgell, 17 (2004), pp. 139-142 y 146-147; JARDÍ ANGUERA, Montserrat, Mestres entalladors..., pp. 271-276; YEGUAS I GASSÓ, Joan, “Encàrrecs artístics (1505-1517) derivats del testament de Galceran de Requesens: Barcelona, Montserrat i Palamós", Estudis del Baix Empordá, 34 (2015), pp. 229.

10 YEGUAS I GASSÓ, Joan, L'escultura a Catalunya..., p. 84.

11 MADURELL MARIMÓN, José Ma , “Los maestros de la escultura renaciente en Cataluña. Martín Díez de Liatzasolo", Anales y Boletín de los Museos d Arte de Barcelona, III, 1 (1945), pp. 10-28, 42-43. GARRIGA RIERA, Joaquim, “Un 'escultor sin obra' del siglo XVI: mestre Joan de Tours, imaginaire, ciutadà de Barcelona", Homenaje al profesor Martín González, Valladolid, Universidad, Secretariado de Publicaciones, 1995, pp. 343-355; YEGUAS I GASSÓ, Joan, “So- 
El 30 de junio de 1522 el lugarteniente del baile general de Cataluña informó al baile de Lérida que había muerto en Guisona "un home alemany qui's nomenave mestre Girart, ymaginayre"12 y que el obispo de Lérida le adeudaba 20 ducados de un retablo finalizado y otros 20, los beneficiados de una cofradía identificada por Madurell como la de Santa María la Antigua de la seo ilerdense.

Se ha considerado que era de origen centroeuropeo y concretamente alemán, pero todos los artistas de los siglos XV y XVI con el apellido Spirin, Spierincks, Spirincks, Spierinck... registrados en el diccionario AKL son neerlandeses ${ }^{13}$. Ciertamente el Brabante formaba parte del Imperio alemán y Girart pudo presentarse con todo merecimiento como "magistrum Girardum, alamanum"14 y se comprende que dijera "yo no sé escriure la letra catalana perquè yo só alamany"15.

\section{La obra del ayuntamiento de Aldenarda y la escultura de Gilles/Gillis SpierincK}

El ayuntamiento de Aldenarda (Flandes) se levantó rápidamente de 1526 a 1536 y es uno de los ejemplos más conseguidos de edificio público al modo del Gótico de Brabante, junto con los de Bruselas y Lovaina. Construido con piedra local, poco resistente a la intemperie, se renovó completamente con piedra francesa en el siglo XIX. Las piedras originales y casi toda la decoración escultórica exterior fueron sustituidas piedra a piedra ${ }^{16}$. En el edificio

bre l'escultor Martí Díez de Liatzasolo (circa 1500-1583)", Locus Amoenus, 5 (2000-2001), pp. 179-194; YEGUAS I GASSÓ, Joan, L'escultura a Catalunya..., pp. 182-186.

12 MADURELL MARIMÓN, José Ma “ “Escultores renacentistas..., p. 313, doc. 40.

13 AKL Allgemeines Künstlerlexikon. Die Bildenden Künstler aller Zeiten und Völker y, especialmente, Allgemeines Künstlerlexikon Internationale Künstlerdatenbank. AKL-World Biographical Dictionary of Artists, München - Leipzig, Thomsom. K. G. Saur Electronic Publising, 2005, 20 ed. en CD (existe edición posterior online de De Gruyter).

14 Freixas señaló que podía ser alemán o flamenco, en realidad posiblemente del Brabante. FREIXAS I CAMPS, Pere, “Documents per a l'art renaixentista català. L'escultura gironina a la primera meitat del Cinc-cents", Annals de l'Institut d'Estudis Gironins, 28 (1986), p. 253, nota 18. 15 AINAUD, J[oan] y VERRIÉ, F[rederic] P[au], “El retablo del altar..., p. 50, doc. XIX del 1 de mayo de 1511.

16 VAN KERKHOVEN, Geertrui, "Steenrijk stadhuis Oudenaarde", Openbaar Kunstbezit in Vlaanderen (OKV), 1 (2003), p. 13. Argumenta que el ayuntamiento se ha renovado piedra a piedra pero que conserva el aspecto original hasta en el más mínimo detalle. Aprovecho para agradecer la atención de Hilde Avet y de Geertrui van Kerkhoven del MOU (Museum Oudenaarde en de Vlaamse Ardennen), pues nos facilitaron poder ver y fotografiar las zapatas de la volkszaal. Igualmente agradezco a Jan Plantinga la ayuda que me ha prestado con la variante del neerlandés antiguo presente en la documentación de Aldenarda. 

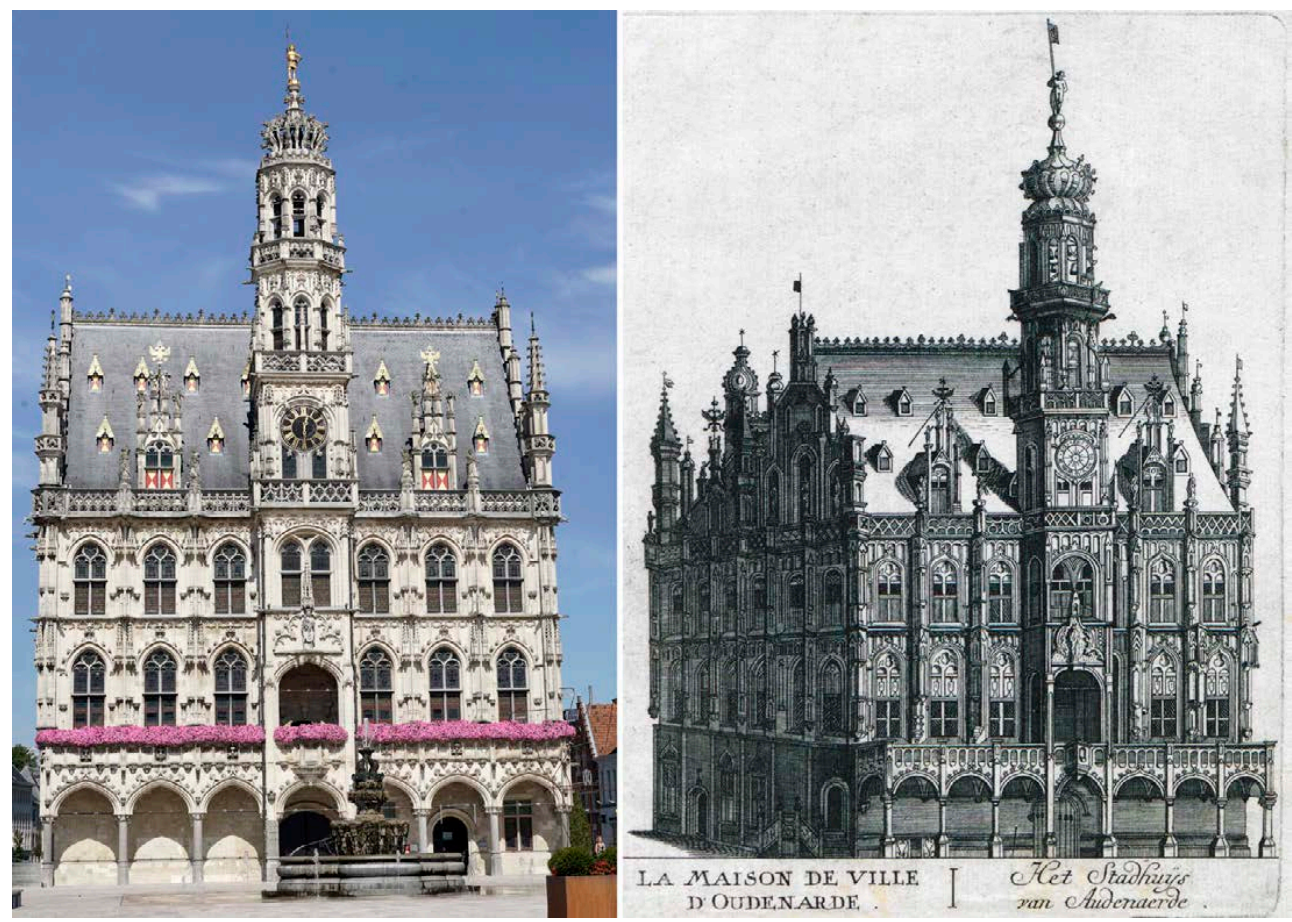

Fig. 2. Ayuntamiento. Hendrik van Pede y Willem de Ronde. 1526-1536. Aldenarda

Fig. 3. Ayuntamiento de Aldenarda. 1711. Museum Plantin Moretus de Amberes

original se habían empleado materiales del país para el revestimiento exterior: piedra de Écaussinnes o Arquennes para las galerías, columnas y ventanas, y piedra de Avesnes para las figuras ${ }^{17}$ (Figs. 2 y 5).

17 Además, establecieron que los ladrillos se fabricaran en lugares bordeados por el Escalda: en Berchem, Zwijnaarde y Amberes. La madera la trajeron de Mons (Bergen) y Valenciennes en Henao (Hainaut/Henegouwen), y de Tournay (Tournai/Doornik). El hierro, de España; VAN DER MEERSCH, Désiré Joseph, “Description architectonique de l'hôtel-de-ville d'Audenarde, considéré comme monument du génie d'Artistes Belges du XVI ${ }^{e}$ siècle", Messager des sciences et des arts, 6 (1829-1830), Gand, P. F. de Goesin-Verhaeghe, pp. 81-84 y 101; VAN CAUWENBERGHE, Edouard-Fr., Lettres sur l'histoire d'Audenarde, Audenarde, F. van Peteghem-Ronsse, [1847], p. 211; VAN LERBERGHE, Lodewyk y RONSSE, Jozef, “Documenten. Fakende de Bouwing van het Stadhuis te Audenaerde", en Audenaerdsche mengelingen, $3^{\text {de }}$ Deel, Audenaerde, Drukkery van F. van Peteghem-Ronsse, 1848, pp. 322, 336-362. La piedra de Écaussinnes y Arquennes es la llamada piedra azul de Henao -“blauwe steenen... eschaudien steenen", "exauchiensteenen", "Cauchines of Herkines", "ordunsteenen"-. La piedra de Avesnes -Avesnes-Le-Sec, en Henao, entre Valenciennes y Cambray- es una piedra blanca usada en catedrales y ayuntamientos -“avennesteen", en la documentación de Aldenarda-. Explotada en galerías subterráneas, se trabaja fácilmente, pero le afectan las heladas. Fue empleada en los ayuntamientos de Lovaina y Aldenarda y ha sido reemplazada por otra piedra semejante traída de Lorena y Borgoña. Se comenta la piedra blanca de Avesnes utilizada para 
Contamos con un grabado de $1711^{18}$ (Fig. 3) que ha sido abierto con detalle suficiente como para asegurar que la obra actual sigue fielmente la original. Ha perdido figuras del remate y las esculturas de Felipe el Hermoso como rey de Castilla, del emperador, de sus esposas y de los hijos de Carlos $\mathrm{V}$ en la galería exterior ${ }^{19}$. Persevera la figura en metal dorado conocida como Hanske de krijger -Juan el guerrero- que remata la torre y parece representar a un soldado imperial enarbolando el pendón de la ciudad. Muy dañadas han llegado las figuras alegóricas de las virtudes -en mejor estado se conserva la Justicia- situadas, como las imágenes de los reyes, en el remate de los pilares que separan los paños del edificio. Igualmente perviven algunos amorcillos originales y algunas otras imágenes.

En el exterior, son fruto de la restauración los putti que levantan las armas imperiales -éstas en hierro dorado- en el adorno de las ventanas del tejado. Las figuras las hizo Pauwels van der Schelden y los amorcillos son semejantes a los que se ven en el portal de la cámara de los regidores. En cambio, la imagen de María situada en el primer cuerpo del beffroi/belfort-casi siempre se denomina torre en la documentación de Aldenarda- se encargó a Adriaen van Hoorick ${ }^{20}$-ahora completamente rehecha-. Tampoco se han conservado las figuras de los profetas, de los planetas ni los animales que estaban en las galerías del beffroi.

El emperador Carlos residió brevemente en Aldenarda en 1521 mientras se resolvía el sitio de Tournay. Charles de Lalaing, que era chambelán desde tiempos de Maximiliano, gobernador del castillo de Borgoña en Aldenarda y hermano de Antoine de Lalaing -conde de Hoogstraten y acompañante de Carlos en su primer viaje a España-, acogió al rey y en 1522 fue recom-

tallar estatuas en, CHRISTYN, Jean Baptiste, Les Delices des Pais-Bas contenant une description generale des XVII Provinces. Edition nouvelle, divisée en III Volumes, augmentée de plusieurs remarques curieuse, E enrichie de figures, Brusselle, chez François Foppens, 1711, T. II, p. 54

18 CHRISTYN, Jean Baptiste, Les Delices des Pais-Bas..., T. I, pp. 282-283.

19 Van der Meersch vio las figuras antes de que comenzaran las labores de restauración. Comentó que, en el remate superior, estaban las estatuas del emperador, y las de los reyes de Castilla, Francia e Inglaterra y sus esposas. VAN DER MEERSCH, Désiré Joseph, “Description architectonique..., pp. 89-90. Algunas fotografías antiguas muestran estas estatuas de difícil identificación. En las cuentas municipales se mencionan las figuras del rey Felipe y de Carlos $\mathrm{V}$, así como del rey de Inglaterra, las esposas y los hijos del emperador: VAN LERBERGHE, Lodewyk y RONSSE, Jozef, “Documenten..., pp. 480-483. Las talló Pauwels van der Schelden y las policromaron Gillis Spierinck, Antonie Membre, Philips Crauwer, Bauwin Ogiers, Jooris Berber, Pauwels Caen, Stevin de Bleeckere y Jooris Moerman.

20 LERBERGHE, Lodewyk y RONSSE, Jozef, “Documenten..., pp. 461-463; la talló con la colaboración de Pieter Bayback. A Van der Schelden le pagaron otra María situada en la Baerpoorte (p. 480). 
pensado con el título de conde de Lalaing ${ }^{21}$. En este último año nació en la ciudad Margarita de Parma, fruto de los amores del joven rey con Johanna van der Gheynst, hermosa huérfana que vivía bajo la protección y al servicio del chambelán y de su esposa. Estos acontecimientos pudieron repercutir en el grandioso empeño por construir un nuevo edificio municipal.

Años más tarde, Aldenarda fue una de las ciudades que se rebelaron contra la política de Felipe II. Tomada por los calvinistas, fue recuperada por Alejandro Farnesio en 1582, benévolo con los habitantes de la ciudad, como hijo de Margarita de Parma. En el siglo XVII, fue asaltada por los franceses comandados por el duque de Orleans en 1658 pero devuelta a España en el Tratado de los Pirineos. Vuelta a tomar por Francia en 1667, la retuvo para si en el Tratado de Aquisgrán de 1668. Asediada por el príncipe de Orange en 1674, fue restituida a España por el Tratado de Nimega de 1678. Fatalmente ardió una gran parte de la villa durante el bombardeo francés de los días 24 y 25 de marzo de 1684 dirigido por Louis de Crevant, mariscal d'Humières.

A pesar de tan azarosa historia, el ayuntamiento conserva bien las principales salas del interior, cuyas paredes, ventanas y vidrieras fueron redecoradas en el siglo XIX.

Desde 1505 los munícipes tuvieron el deseo de ampliar el ayuntamiento y solicitaron planos de una nueva torre o beffroi al arquitecto Jan van der Eecken, que trabajaba en la torre de Santa Walburga. El proyecto no se edificó porque optaron por un plan más ambicioso. En 1525 encargaron trazas a Jan Stassius y Laurens de Vaddere, maestros de obra del ayuntamiento de Gante, pero se inclinaron por la propuesta de Hendrik van Pede o van Pe, arquitecto de Bruselas ${ }^{22}$. A continuación, contrataron la obra con él y con el aparejador Willem de Ronde, arquitecto bruselense que era conocido en Aldenarda por su trabajo en Santa Walburga.

La primera piedra se colocó el 15 de mayo de 1526 en presencia de Philippe de Lalaing, nuevo gobernador de la ciudad. Se aprovechó una sala construida en el siglo XIV -el edificio de las telas o schepenhuis viejo- $\mathrm{y}$, hacia la plaza del mercado, se edificó un gran edificio simétrico situado entre las calles Hoogstraat y Nederstraat. Se compone de planta baja y dos cuerpos

21 CASTELAIN, Rik, “De familie de Lalaing te Oudenaarde $\left(15^{\mathrm{de}}-16^{\mathrm{de}}\right.$ eeuw)", Handelingen van de Geschied- en Oudheidkundige Kring van Oudenaarde van zijn Kastelnij en van den Lande tusschen Maercke en Ronne, 38 (2001), p. 18, con un árbol de la familia.

22 VAN DER MEERSCH, Désiré Joseph, “Description architectonique..., pp. 70-81; VAN CAUWENBERGHE, Edouard-Fr., Lettres sur l'histoire..., pp. 143 y 210; VAN LERBERGHE, Lodewyk y RONSSE, Jozef, “Documenten..., pp. 314-315. En esta publicación se transcribieron las cuentas de la construcción del ayuntamiento de Aldenarda y es una fuente básica citada por todos los historiadores posteriores. Van Pede tuvo como canteros y escultores colaboradores a Willem de Ronde, Cornelis van Pede, Joos van Pede, Pieter Wayback, Bagaige o Bagage, Willem Sprent o Sprunt y Adriaen van Hoorick (p. 373). 
con la torre del reloj en el centro que asciende sobre el resto del edificio con un piso cuadrado y otros dos octogonales para finalizar en una corona imperial rematada por "Juan el guerrero", fundido en 1531 por el platero Willem Blanstrein, con indicaciones de Van Pede ${ }^{23}$.

Durante la construcción del edificio participaron vivamente los regidores que solicitaron traer modelos de otras villas del país y rechazaron algunos trabajos. Aparte de los ayuntamientos de Gante y Bruselas, Adriaen van den Eede aportó un patrón del ayuntamiento de Middelburg (Zelanda) que hacía poco había concluido Rombout Kelderman y sin duda se aprovechó para el cuerpo de la Hoogstraat. También visitaron Cortrique (Courtrai/ Kortrijk), Malinas y Lovaina. Tampoco se conformaron con la propuesta de escalera que pretendía construir Van Pede y enviaron a Vilvoorde a los canteros Hendrik Uutendaele y Willem Baert para estudiar una bóveda y una escalera en espiral que deseaban imitar ${ }^{24}$. Además, hicieron venir a Rombout Kelderman, maestro de las obras del emperador que trabajaba en el edificio del Gran Consejo en Malinas, para que informara sobre cómo construir una escalera más hermosa y más cómoda. Un cantero de Cortrique trajo modelos de las extraordinarias chimeneas de las cámaras municipales de esta ciudad vecina. De nuevo en 1528 enviaron a Cortrique al regidor Jooris de Curte y a un pintor -seguramente Gillis Spierinck a quien, a continuación, se pagan varios modelos- para medir y dibujar la galería del ayuntamiento, y valorar las trazas en la solución que querían dar al coronamiento de las fachadas. De Gante tomaron modelo para el gran armorial del emperador que dispusieron sobre la puerta de entrada a la galería inferior en el cuerpo del beffroi. Pauwels van der Schelden trajo de Gante el patrón para unos grifos que seguramente empleó en el adorno de las armas de Carlos V en el portal de la cámara de los regidores ${ }^{25}$. Artistas de distintos oficios -entre ellos el

23 Una revisión reciente, que recoge la participación de Gillis Spierinck como dorador de la figura, VAN HOECKE, Karl, “De historiciteit achter de stadslegende van 'Hanske de krijger' $\left(15^{\mathrm{de}}-16^{\mathrm{de}}\right.$ eeuw)", Handelingen van de Geschied-en Oudheidkundige Kring van Oudenaarde van zijn Kastelnij en van den Lande tusschen Maercke en Ronne, 56 (2019), pp. 5, 16, 25-29. También, la publicación de la nota anterior y RAEPSAET, Henri, "Un mot sur la statue qui surmonte la tour de la maison de ville d'Audenarde", Annales de la Société royale des beaux-arts et de littérature de Gand, 3 (1848-1850), pp. 170-180.

24 Seguramente esta escalera era obra de Van Pede y Willem de Ronde. De Ronde, arquitecto de Bruselas, trabajaba en la iglesia de Santa Walburga desde 1510 y consta que vivía en Vilvoorde en 1512; VAN LERBERGHE, Lodewyk y RONSSE, Jozef, Audenaerdsche mengelingen, $2^{\text {de }}$ Deel, Audenaerde, Drukkery van Gommar de Vos, 1846, pp. 29-32. Además, los magistrados de Aldenarda enviaron a un emisario a Bruselas y Vilvoorde para que buscara a los maestros Van Pede y De Ronde; p. 341.

25 Los grifos eran tenantes habituales de las armas del emperador. Con anterioridad había tallado las armas de Habsburgo en una zapata de la volkszaal, pero la apariencia de los grifos no debió convencer -con las alas ceñidas al marco, tienen un aspecto poco fiero-. Había he- 


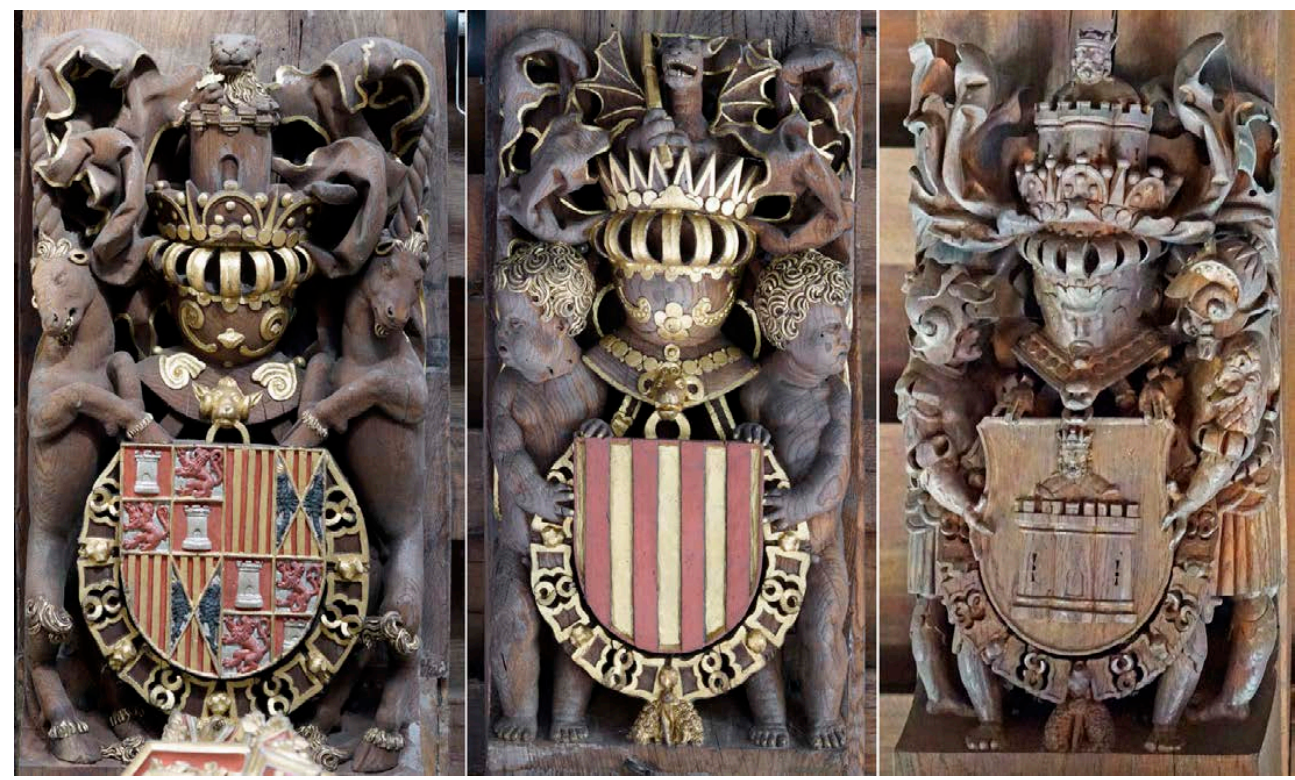

Fig. 4. Escudos de armas de España, Aragón y Burgos. Georges de la Postelerie. 1528. Volkszaal y segundo piso del ayuntamiento de Aldenarda

pintor Gillis Spierinck ${ }^{26}$ - fueron enviados al castillo del conde de Egmont en Zottegem -que estaba ricamente decorado- a tomar modelos para trabajos de hierro, carpintería, cerrajería, zócalos y todo tipo de adornos. Gillis, acompañado de un cerrajero, visitó durante siete días Bruselas, Amberes, Malinas y Lovaina para trazar los cuadrantes y diales de los relojes de estas cuatro villas ${ }^{27}$. Los magistrados eligieron el reloj de Lovaina y enviaron a un orfebre para asegurarse la exactitud.

El edificio se concluyó en 1530 -en marzo el emperador otorgó nuevas ordenanzas municipales y renovó los regidores ${ }^{28}$. Para examinar todo lo construido en piedra vinieron de Amberes los arquitectos Ymans, Van der

cho un gran esfuerzo representativo, pues reprodujo con cierta fidelidad la verdadera corona imperial que se guardaba en Núremberg (ahora en el palacio Hofburg de Viena). Buscó otros modelos para los grifos y viajó a Gante. Los representados en el portal son más expresivos y se asemejan a los que presiden el armorial de Vigil Raber con la fecha de 1522; Vigil Rabers Sterzinger Wappenbüch, f, 1, Weimar, Herzogin Anna Amalia Bibliothek, http://bilderserver.at/ wappenbuecher/VirgilRaberEXAv2_52z2/

26 VAN LERBERGHE, Lodewyk y RONSSE, Jozef, “Documenten..., 1848, p. 425.

27 VAN DER MEERSCH, Désiré Joseph, “Description architectonique..., pp. 85-86, 90-91 y 95; VAN CAUWENBERGHE, Edouard-Fr., Lettres sur l'histoire..., p. 211; VAN LERBERGHE, Lodewyk y RONSSE, Jozef, “Documenten..., pp. 315, 336, 341, 345, 392-428.

28 VAN LERBERGHE, Lodewyk y RONSSE, Jozef, Audenaerdsche mengelingen, $2^{\text {de }}$ Deel..., pp. 70-71. 
Meere y Van den Broecke. El embellecimiento del exterior terminó en 1531 y la decoración del interior en 1536. En tan breve tiempo se gastaron 86658 libras parisinas ${ }^{29}$. Construido con un gran esfuerzo de la comunidad, seguramente pretendía atraer al emperador e igualar Aldenarda con las grandes ciudades de Flandes y Brabante; no en vano los regidores trajeron modelos -y arquitectos- de Gante, Bruselas, Lovaina, Malinas, Middelburg y Cortrique. Es un ejemplo impresionante de la bonanza económica de la villa en la primera mitad del siglo XVI, cuando sus talleres de tapices abastecían las cortes de Europa.

En el adorno interior participaron varios escultores. Desde el comienzo de las obras, la dirección de la escultura, o al menos las obras más representativas del exterior y algunas del interior, se confió a Pauwels van der Schelden, magnífico escultor local. Se conservan las cuentas municipales de todo el proceso constructivo y por ellas se conocen los nombres del resto de los escultores: Gillis Spierinck, Adriaen van Hoorick, Jooris/Georges de la Postelerie, Michiel Pieters y Joseph de Clercq ${ }^{30}$.

Previamente se habían pagado a un pintor de Gante 17 dibujos de escudos de armas. Posiblemente fuera Jacob Nauwinc al que, con anterioridad, consta que le abonaron dos dibujos para las zapatas y otros cuatro para Hendrik van Pede ${ }^{31}$. Consta que los modelos del pintor gantés iban con "timbres up A, B, C", es decir, con timbre completo: corona, yelmo, burelete, cimera y lambrequines (Fig. 4). Los escultores se repartieron la talla de las zapatas de los dos pisos del ayuntamiento que están adornados con los escudos de los territorios del Imperio. Ciertamente llevan timbre cumplido y tenantes. Se abonaron en 1527-1528. Van der Schelden cobró por los escudos del emperador, Granada, condado Palatino (Henao), Portugal, Carniola, Habsburgo ${ }^{32}$,

29 VAN DER MEERSCH, Désiré Joseph, “Description architectonique..., pp. 100-102.

30 VAN DER MEERSCH, Désiré Joseph, “Description architectonique..., pp. 94-98; VAN LERBERGHE, Louis, Het portael der kollegiekamer van het Stadhuis te Audenaerde, en Pauwels van der Schelden, Beeldsnyder, Audenaerde, Drukkery van Gommar de Vos, 1842, p. 2. VAN CAUWENBERGHE, Edouard-Fr., Lettres sur l'histoire..., pp. 215-219; VAN LERBERGHE, Lodewyk y RONSSE, Jozef, “Documenten..., pp. 364, 369, 398 y 426; VANDERSTRAETEN, Edmond, "Les maitres de Paul Vanderschelden, auteur du portail de la salle échevinale à Audenarde", Annales de l'Académie d'Archéologie de Belgique, 10 (1855), pp. 393-401; VANDEVELDE, Marie Josephe, Het Stadsmuseum van Oudenaarde: Kataloog, Gent, Federatie voor Toerisme in Oost-Vlaanderen, 1961, p. 6.

31 VAN LERBERGHE, Lodewyk y RONSSE, Jozef, “Documenten..., pp. 363, 365. A Nauwinc le pagaron a 10 chelines por cada dibujo. Con anterioridad, había entregado otros cuatro dibujos sobre papel -sin especificar su contenido- al arquitecto Hendrik van Pede; le pagaron 12 chelines por los cuatro (p. 337). Al pintor de Gante le abonaron 4 libras parisinas por todo, a 5 chelines por cada traza.

32 La zapata de Habsburgo es la que acaba en la corona imperial con águila bicéfala y en el pecho escusón de Austria. Así se representan las armas del emperador Carlos V en el armorial 
Zelanda y Carintia33; Gillis Spierinck, Portugal, Cléveris, Sicilia, Brabante, Croacia, otra mitad de Brabante, Güeldres, Borgoña, y Ferrette o Pfirt (Fig. 1); Van Hoorick hizo dos escudos: de Castilla, de España y León -“Spaengnen ende Leons", en realidad de Castilla y León-, otro más sin identificar y una última zapata con las armas de Flandes; Georges de la Postelerie, España entre dos unicornios, Holanda, Kiburgo, Limburgo, alta Sicilia, Valencia y Aragón; Michiel Pieters, Navarra, Nápoles, Flandes, Austria, Artois y dos mitades con estrellas de Tirol que, en realidad, corresponden a Zilly ciudad presente en los armoriales imperiales de la época, aunque la mitad de escudo que corresponde a Tirol también le ha de pertenecer; Joseph de Clercq talló los de Lorena, Luxemburgo, Burgau ${ }^{34}$, Dalmacia, Toledo, el ducado de Estiria y Eslavonia -representado con las armas de Windische Mark, la marca eslovena, que muestran un sombrero esloveno-. Los dos últimos escudos, pensados para los extremos de una sala, reparten las armas en dos mitades cada uno. Las zapatas se encuentran en las cabezas de las vigas que soportan el techo del primer y del segundo piso del edificio. En el primero se sitúan las salas principales: una sala general de recepción -volkszaal-y la sala de los regidores o schepenzaal que es el espacio más decorado. Ambos espacios forman una planta en L que se repite en el segundo piso y se extiende a lo largo del frente que da a la plaza del mercado y por la calle Hoogstraat.

Pauwels, además, se encargó, en 1528, de la escultura en piedra de las chimeneas que, de modo simplificado, siguen los modelos de Cortrique realizados pocos años antes. La chimenea de la sala de los regidores se adorna

de Nancy; Nancy, Bibliothèque Mediathèque, Ms. 1727, f. 4; http://bmn-renaissance.nancy. fr/items/show/1240. También en la contraportada de la crónica de Núremberg de Sigismundus Meisterlin y Hecktor Mülich -Ausburger Chronik de 1457- la piña de la localidad, sobre un escudo partido con los colores de Austria, está recogida por el águila bicéfala con corona imperial y escusón de Austria en el pecho. Durante el gobierno de Maximiliano el escusón compartía las armas de Austria y Borgoña. A Carlos V le correspondía un escusón distinto y más complejo, pero al principio se empleó el sencillo, con las armas de Austria que, con anterioridad, había empleado Federico III (1415-1493).

33 En la documentación publicada en 1848 se transcribió Carintia (Carente), que es un territorio del Imperio, p. 369. En 1829 y 1842 Van der Meersch y Van Leberghe habían publicado que se pagaron a Pauwels van der Schelden las armas de Tarento, en lugar de las de Carintia; VAN DER MEERSCH, Désiré Joseph, “Description architectonique..., p. 95; VAN LERBERGHE, Louis, Het portael..., p. 5. No hemos visto el escudo de Carintia. Lógicamente tampoco se localizan las de Tarento que no es un título de Carlos V, aunque se podrían confundir con las de Sicilia citra Pharum -labradas por De la Postelerie- ya que Calabria y Apulia se incorporaron en 1501 a Aragón con Fernando el Católico y eran conocidas como Sicilia citra Pharum.

34 No hemos visto el escudo de Burgau. Sí aparecen las armas de Burgos pero son del estilo de Georges de la Postelerie. Van der Meersch, que fue el primero en emplear la documentación municipal de Aldenarda, a la vista del escudo, propuso Burgos en lugar de Burgau, pero no es obra de Joseph de Clercq: VAN DER MEERSCH, Désiré Joseph, “Description architectonique..., p. 95. 

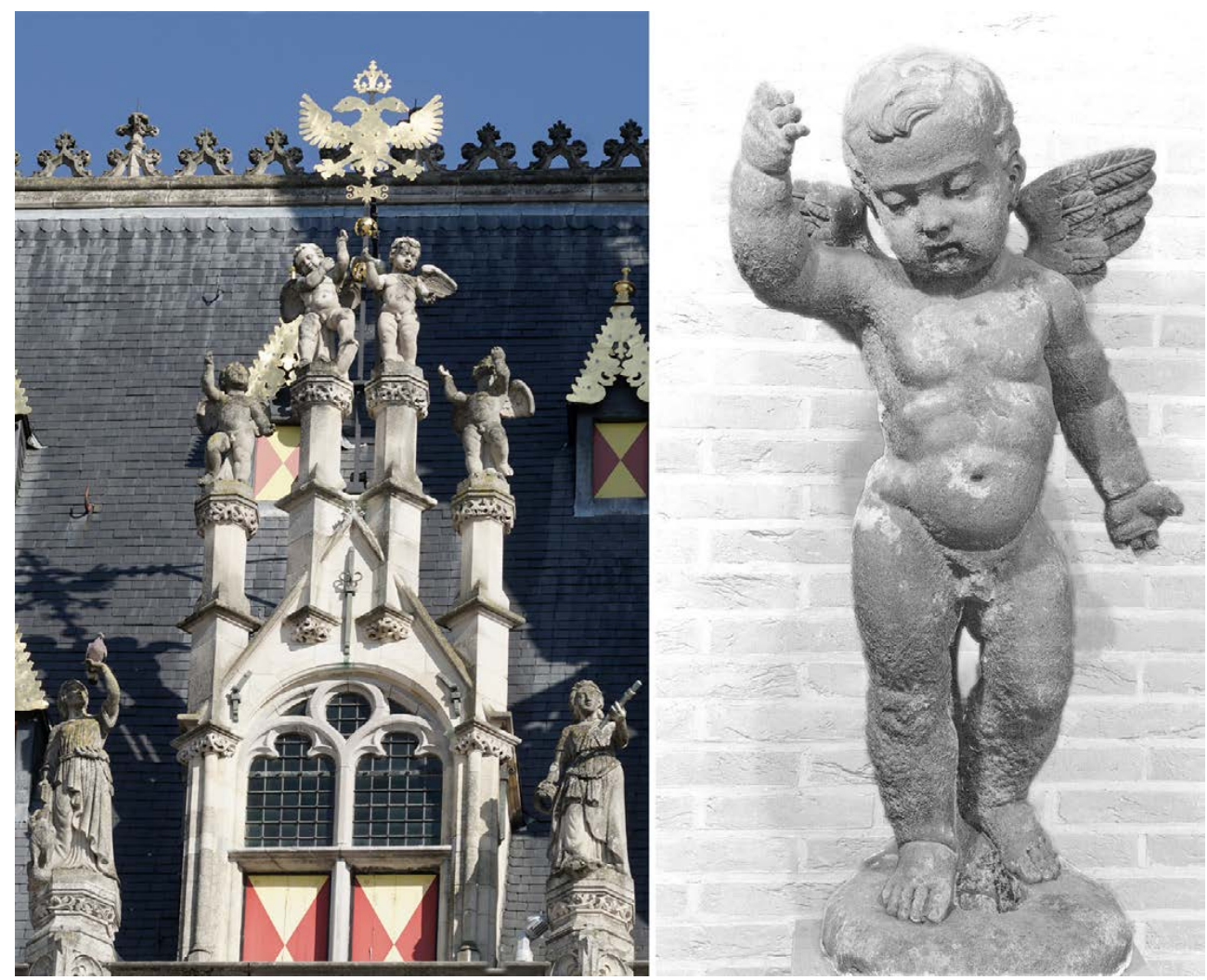

Fig. 5. Amorcillos. Pauwels van der Schelden. 1529. MOU, ayuntamiento de Aldenarda. Foto, KIK-IRPA

con las figuras originales de María entre las representaciones de Justicia y Esperanza. En 1529 talló los doce niños que coronan las grandes lucernas de la techumbre, los florones de las ventanas y las figuras alegóricas de los planetas que datan de 1534. En 1536, una imagen de María para la puerta Baer -o de Tournay-, un ángel para el ayuntamiento y las estatuas de Felipe el Hermoso y Carlos V para la galería que recorre la cornisa del ayuntamiento. También se encargó de esculpir los florones de 22 ventanas. (Fig. 5)

En febrero de 1531 contrató, junto con Pierre de Merlier, entallador de Etikhove, el magnífico portal de la sala de los regidores, concluido en 1534 sin que se sepa si participó alguno de los escultores que, con él, hicieron las zapatas figurativas de los dos pisos del ayuntamiento. Labrado en madera de Mons, fue tasado por el escultor Barthélemy Portant, el ensamblador Liévin Opzaet, artistas de Gante, y Blasius Rasses, experto en la Antigüedad. Es obra maestra de Van der Schelden, de prolija decoración al romano: en las puertas, amorcillos y vegetación a candelieri; en la parte superior, las armas 

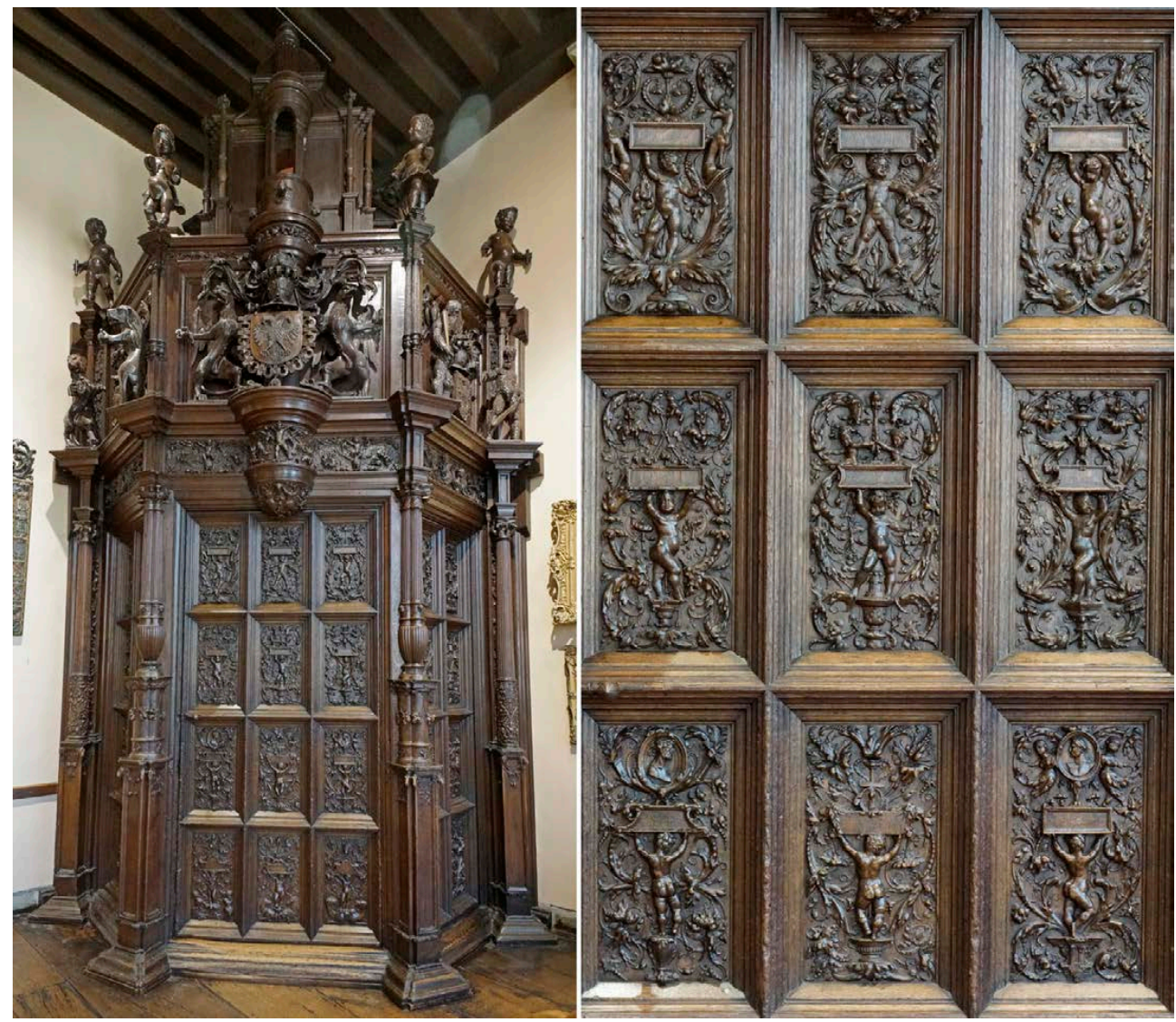

Fig. 6. Portal. Pauwels van der Schelden y Pierre de Merlier. 1531-1534. Schepenzaal, ayuntamiento de Aldenarda

de Carlos V, de Flandes y de Aldenarda con timbre y tenantes semejantes a los de las zapatas. Culmina en un cuerpo con amorcillos de bulto redondo y un edificio influido por la nueva arquitectura ${ }^{35}$. (Fig. 6)

35 La primera noticia sobre el portal de Van der Schelden y la tasación de la obra, RAEPSAET, J[an] J[oseph], "Lettre adressée au Secrétaire de la Société royale de Beaux-Arts et de Littérature á Gand", Messager des sciences et des arts, Gand, P. F. Goesin-Verhaeghe, 1823, pp. 344-348. VAN LERBERGHE, Louis, Het portael..., pp. 3-4. Panicelli, residente en Gante, reprodujo en yeso el portal en 1842 e hizo copias para el gabinete del conde Amedée de Beauffort y el duque de Arenberg en Bruselas, para las academias de Amberes, Bruselas, Lille, Valenciennes y Amiens y los museos del Louvre y Berlín; VAN CAUWENBERGHE, Edouard-Fr., Lettres sur l'histoire..., pp. 218-219; VAN LERBERGHE, Lodewyk y RONSSE, Jozef, “Documenten..., pp. 462-478; MUQUARDT, Charles, Monuments d'architecture et de sculpture en Belgique. Le Brabant et les Flandres, Paris, Delaroche, Pilon et comp., 1857, con notas históricas de François Stappaerts y litografías de F. Stroobant, s.p. ; MARCHAL, Edmond, Mémoire sur la sculpture aux Pays-Bas pendant les XVIIe et XVIIIe siècles, Bruxelles, F. Hayez, 1877, p. LVI. 
Van der Schelden desplegó en su obra una gran cantidad de amorcillos derivados de los grabados inspirados en paneles decorativos italianos y en los que reproducían las composiciones de Rafael en la Farnesina. Estos paneles de roleos de acanto, decoración a candelieri y amorcillos juguetones prontamente se reprodujeron y recrearon en grabados de artistas del Norte como Durero, Hans Burgkmair el Viejo o Sebald Beham. El portal de Van der Schelten es contemporáneo a la decoración de la cámara de los regidores del Franconato de Brujas, obra de 1529 diseñada por Lancelot Blondeel con la participación de varios escultores entre los que destaca Guyot de Beaugrant, que acabó su días en La Rioja. El adorno en estas dos obras, con roleos vegetales, figuras metamorfoseadas y disposición a candelieri, guarda cierto parecido. Las contorsiones de los amorcillos de Aldenarda se asemejan a los tallados por Guyot, e incluso los doce niños que Van der Schelden dispuso en las ventanas del tejado recuerdan a los que en Brujas levantan los tondos de Felipe el Hermoso y Juana I de Castilla.

Pauwels van der Schelden era escultor de Aldenarda, hijo de Jan van der Schelden que desde finales del siglo XV trabajó en la iglesia de Santa Walburga. Van Hoorick podría ser oriundo de Amberes ${ }^{36}$ y otros podrían formar parte del equipo de los arquitectos de Bruselas. Si Gillis Spierinck fue hermano de Arnao de Bruselas hubo de venir de esta localidad, como el arquitecto director. De hecho, se le confiaron bastantes acciones en las que se necesitaba también la opinión de Van Pede.

Como Gillis fue escultor y pintor, hemos de referirnos a otros pintores del mismo apellido, pues se ha sugerido que pudiera ser hijo de Jan Spierinc pintor documentado en Aldenarda en $1512^{37}$. Entre Bruselas y Gante vivieron algunos artistas calígrafos e iluminadores desde mediados del siglo XV, aunque es improbable que tuvieran relación de parentesco con los artífices del siglo XVI. El más sobresaliente fue el miniaturista Nicolas/Claeis Spierinc documentado de 1453 a 1499 y fallecido en 1500 o 1501. Sus orígenes familiares

36 Michiel van Hoericke es mencionado entre los escultores amberinos que otorgaron poder en un pleito contra los pintores el 23 de marzo de 1520; VAN DER STOCK, Jan, "Antwerps beeldhouwwerk: over de praktijk van het merktekenen", en VAN VLIERDEN, C. y SMEYERS, M. (eds.), Merken opmerken. Merk- en meestertekens op kunstwerken in de Zuidelijke Nederlanden en het Prinsbisdom Luik. Typologie en methode, Leuven, Puitgeverij Peeters, 1990, p. 140.

37 VAN LERBERGHE, Lodewyk y RONSSE, Jozef, Audenaerdsche mengelingen, $6^{\text {de }}$ Deel, Audenaerde, Drukkery van F. van Peteghem-Ronsse, 1854, pp. 286 y 419; pintó un retrato, y a un hombre y una paloma en el reloj municipal. En realidad, se había propuesto como ascendiente de Gillis al miniaturista Jan Spierinc, hijo de Nicolas, documentado en el siglo XV: VANDER STRAETEN, Edmond, “Épisodes de l'histoire de la sculpture en Flandre d'après des documents inédits. Audenarde et Ypres", Bulletin des Commissions Royales d'Art et d'Archéologie, 31 (1892), p. 279 ; RAMAKERS, Bartholomeus Adrianus Maria, Spelen en figuren. Toneelkunst en processiecultuur in Oudenaarde tussen Middeleeuwen en Moderne Tijd, Amsterdam, Amsterdam University Press, 1996, p. 81. 
procedían de Zwijndrecht, cerca de Amberes. Tuvo dos hijas y tres hijos: Jan -fallecido en 1490-, y Nicolas II -establecido en Inglaterra- siguieron el oficio paterno. Nicolas trabajó en Bruselas -donde en 1469 acabó las miniaturas de las Ordenanzas municipales- y Lovaina, pero sobre todo vivió en Gante donde colaboró con el iluminador Lieven van Lathem (1430-1493) ${ }^{38}$. De caligrafía muy elegante, trabajó para el duque de Borgoña Carlos el Temerario.

La primera noticia sobre Gillis Spierinck data del 11 de septiembre de $1523^{39}$ y lo califica de imaginero -beeldesnydere, término con el que se denomina al escultor Jan II Borman, o a Pauwels van der Schelden en la documentación de Aldenarda ${ }^{40}$-. Sin embargo, el 19 de septiembre de 1527, al contratar la pintura del retablo mayor de Nokere, población próxima, se le denominó pintor -scildre-y se le contrató para policromar y estofar ${ }^{41}$. Ahora bien, los clientes habían de saber de su habilidad con la escultura porque el concierto tenía previsto que debía reparar las imágenes si alguna estaba deteriorada o se veía afectada en el proceso. También debía fabricar cuatro columnas con sus capiteles para levantar otros tantos ángeles que ya tenían y, lo que es más importante, tallar una imagen de María rodeada de rosas doradas que debía disponerse en el altar sobre un alto pilar, es decir un "marianum" ${ }^{42}$ : una escultura exenta de María sobre una media luna y rodeada de rayos solares:

38 VAN DER AA, A. J., Biographisch woordenboek der Nederlanden. Deel 17. Tweede stuk, Haarlem, J. J. van Brederode, 1874, p. 910: http://www.dbnl.org/tekst/aa_001biog21_01/colofon. php;DE SCHRYVER, Antoine, The Prayer Book of Charles the Bold. A Study of a Flemish Masterpiece from the Burgundian Court, Los Angeles, The Getty Publications, 2008, pp. 31-32 y 65-83; KREN, Thomas, Illuminated Manuscripts from Belgium and the Netherlands in the J. Paul Getty Museum, Los Angeles, Getty Publications, 2010, p. 21.

39 VAN LERBERGHE, Lodewyk y RONSSE, Jozef, Audenaerdsche mengelingen, $4^{\text {de }}$ Deel, Audenaerde, Drukkery van F. van Peteghem-Ronsse, 1850, pp. 398-399. Resolución de una demanda con el gremio de San Antonio.

40 VAN LERBERGHE, Lodewyk y RONSSE, Jozef, “Documenten..., pp. 325, 433 y 480.

41 VAN LERBERGHE, Lodewyk y RONSSE, Jozef, Audenaerdsche mengelingen, $1^{\text {ste }}$ Deel, Audenaerde, Drukkery van Gommar de Vos, 1845, pp. 299-302; VANDER STRAETEN, Edmond, "Notes sur quelques peintres et sculpteurs belges, 1414 à 1760", en Messager des sciences historiques des arts de la bibliographie de Belgique, Gand, Imprimerie et Lithographie de L. Hebbelynck, 1856, pp. 341-342; VANDAMME, Erik, De polychromie van Gotische houtsculptuur in de Zuidelijke Nederlanden: materialen en technieken, Brussel, Koninklijke Academie voor wetenschappen, letteren en schone kunsten van België, 1982, pp. 212-213; HELMUS, Liesbeth M., Schilderen in opdracht: Noord-Nederlandse contracten voor altaarstukken 1485-1570, Utrecht, Centraal Museum, 2010, pp. 376-377; https://pure.uva.nl/ws/files/744423/71745_thesis.pdf

42 Sobre el "marianum" en Países Bajos, SMEYERS, Maurits, "Het Marianum of Onze-Lieve-Vrouw-in-de-zon: Getuige van een laat-middeleeuwse devotie in de Nederlanden en in Duitsland", Nederlands Kunsthistorisch Jaarboek (NKJ) / Netherlands Yearbook for History of Art, 45 (1994), pp. 270-299. Vinculadas a la devoción del rosario que difundieron los dominicos, se encuentra sobre todo en los obispados de Utrecht y Lieja, pero alcanza Renania, el sur de Alemania, el Brabante y, en esta ocasión, Flandes. 
pulchra ut luna, electa ut sol. Como se pidió en Nokere, suele ir enmarcada por un rosario. En esta ocasión se dispondría en el altar, en lugar de colgar de la bóveda como sucede en los casos más llamativos.

Desde el comienzo de las obras en el ayuntamiento, Gillis tuvo una considerable actividad únicamente superada por Van der Schelden. En 1527 cobró el dibujo de un pilar ${ }^{43}$, y varias zapatas para las vigas: unas enteras, con las armas de Portugal, Cléveris, Sicilia, Brabante y Croacia; una mitad de Brabante; y las de Güeldres, en otras dos mitades unidas ${ }^{44}$. Para realizar con precisión los escudos de armas, los magistrados le encargaron investigar el armorial del emperador Carlos V en lo referido a los territorios de los pueblos germánicos, de los Países Bajos y los demás -duutschen landen ende anderseins $-^{45}$. Habrá que suponer que el pintor de Gante aportó los dibujos de las armas de los territorios hispánicos. En 1528 doró la figura de San Miguel -y las flores inferiores-con oro fino. La escultura era de cobre y, en el noroeste, remataba la torre junto a la sala de telas antigua, en la parte trasera del edificio y contraria al beffroi $i^{46}$. También doró con oro fino 12 hombres, 8 mujeres, un salvaje, dos leones, plumas y cuatro arneses, seguramente de los tenantes y cimeras de las zapatas labradas por él y sus compañeros en la volkszaal ${ }^{47}$. Igualmente le abonaron cantidades bastante elevadas por pintar y estofar elementos del beffroi y del ático hechos en piedra de Écaussinnes, como eran figuras, un sagitario - para el reloj-, columnas, los doce niños que talló Van der Schelden, y el adorno que daba a la calle Hoogstraat ${ }^{48}$. Destacados con policromía los elementos escultóricos, la apariencia sería muy distinta de la

43 VAN LERBERGHE, Lodewyk y RONSSE, Jozef, “Documenten..., p. 341. Se empleó madera de los bosques de Mons, p. 339.

44 VAN LERBERGHE, Lodewyk y RONSSE, Jozef, “Documenten..., p. 369.

45 VAN LERBERGHE, Lodewyk y RONSSE, Jozef, “Documenten..., p. 370. Se ocupó cuatro días, seguramente en realizar dibujos precisos con los escudos a disponer en las zapatas. En una de las paredes de la volkszaal se representa un águila bicéfala con las armas habituales del emperador rodeadas por la cadena del Toisón, todo ello enmarcado con las columnas del Plus oultre. Se pintaron en la redecoración de la sala durante el siglo XIX, pero en las garras del águila se advierte la existencia de un dibujo anterior o tal vez un pentimenti; VAN KERKHOVEN, Geertrui, “Steenrijk stadhuis..., p. 20. En cualquier caso, si se pintó un águila imperial en el siglo XVI no se puede hacer corresponder con este dibujo, ya que únicamente están las armas habituales del emperador y no se trata del águila quaternion.

46 VAN LERBERGHE, Lodewyk y RONSSE, Jozef, “Documenten..., pp. 390 y 404; perdido el original, se ha colocado en 1964 otro San Miguel de bronce; VAN KERKHOVEN, Geertrui, “Steenrijk stadhuis..., p. 14.

47 VAN LERBERGHE, Lodewyk y RONSSE, Jozef, “Documenten..., pp. 392-394.

48 VAN LERBERGHE, Lodewyk y RONSSE, Jozef, “Documenten..., pp. 396-97; algunos de estos elementos los habían labrado Willem de Ronde, Cornelis van Pe, Pieter Wayback, Stevin Treinnan, Adriaen van Hoorick, Jacob Coolman, Jan van Gaesberghe y Hendrick Goessins, canteros y escultores. 
actual, más cercana a las imágenes del llamado Tejadillo de oro en Innsbruck. La pintura y los panes de oro aportaban lujo, vistosidad y durabilidad a la piedra de Avesnes.

En el mismo año de 1528 Spierinck hizo las zapatas con las armas de Borgoña y Ferrette. Cobró por un león que, a modo de veleta, ocupaba la parte alta que da a la calle Neder y por un patrón de un dial para el reloj pintado sobre piedra ${ }^{49}$. En los años siguientes, 1529-1530 cuando se concluyó la edificación del edificio, adornó con pintura una puerta de hierro de la torre Ronskin, varias ventanas y otros elementos del edificio, de la sala de los regidores, de la galería superior, de la torre y del coronamiento exterior. Aplicó a las manecillas del reloj pan de oro traído de Amberes ${ }^{50}$. Además, junto con el cerrajero Adriaen Meynfroet, visitó Lovaina, Malinas y Bruselas para dibujar los diales de los relojes de sus torres. Con dos regidores y un herrero acudió al castillo de Zottegem para tomar modelos de herrería, cerrajería, zócalos, carpintería ${ }^{51}$... En 1531 doró la figura de "Juan el guerrero". Durante los años 1533 a 1536 continuó su actividad como pintor de elementos decorativos del interior y del exterior: policromó las estatuas de la cámara de los regidores, los escudos de armas, las alegorías de los planetas, las estatuas del emperador, del rey Felipe el Hermoso y un ángel -obras de Van der Schelden-. En él confiaron el adorno del altar de la capilla anexa a la sala de los regentes ${ }^{52}$.

Como escultor, únicamente se conservan algunas de las zapatas repartidas en los dos pisos principales del Ayuntamiento. Hemos visto que se pagó a un pintor de Gante el dibujo preciso de 17 zapatas y otras dos a Jacob Nauwinc. También Spierinck estuvo comisionado 4 días para averiguar las armas del Imperio y Pauwels acudió a Gante para realizar el dibujo de unos grifos, seguramente para las armas del emperador en el portal de la schepenzaal ${ }^{33}$. Existía en el territorio un fuerte interés por la heráldica que se vio incrementado con la proclamación de Carlos, nacido en Gante, como emperador y rey de unos territorios vastísimos. Las insignias heráldicas eran omnipresentes en las conmemoraciones, en los recibimientos, en las cabalgatas, en los festejos, en las pompas fúnebres y en la guerra. Evocaban territorios y hablaban de poder. Los príncipes y las órdenes militares más exclusivas -como la del Toisón de oro- disponían de reyes de armas y las insignias personales se

49 VAN LERBERGHE, Lodewyk y RONSSE, Jozef, “Documenten..., pp, 398, 405 y 417.

50 VAN LERBERGHE, Lodewyk y RONSSE, Jozef, “Documenten..., pp. 420, 424, 426, 429430, 446, 448-449 y 456.

51 VAN LERBERGHE, Lodewyk y RONSSE, Jozef, “Documenten..., pp. 424-425.

52 VAN LERBERGHE, Lodewyk y RONSSE, Jozef, “Documenten..., pp. 468, 474, 476, 477, 479-484.

53 Se ha señalado que fueron para el remate del beffroi; VAN HOECKE, Karl, "De historiciteit..., p. 25. 


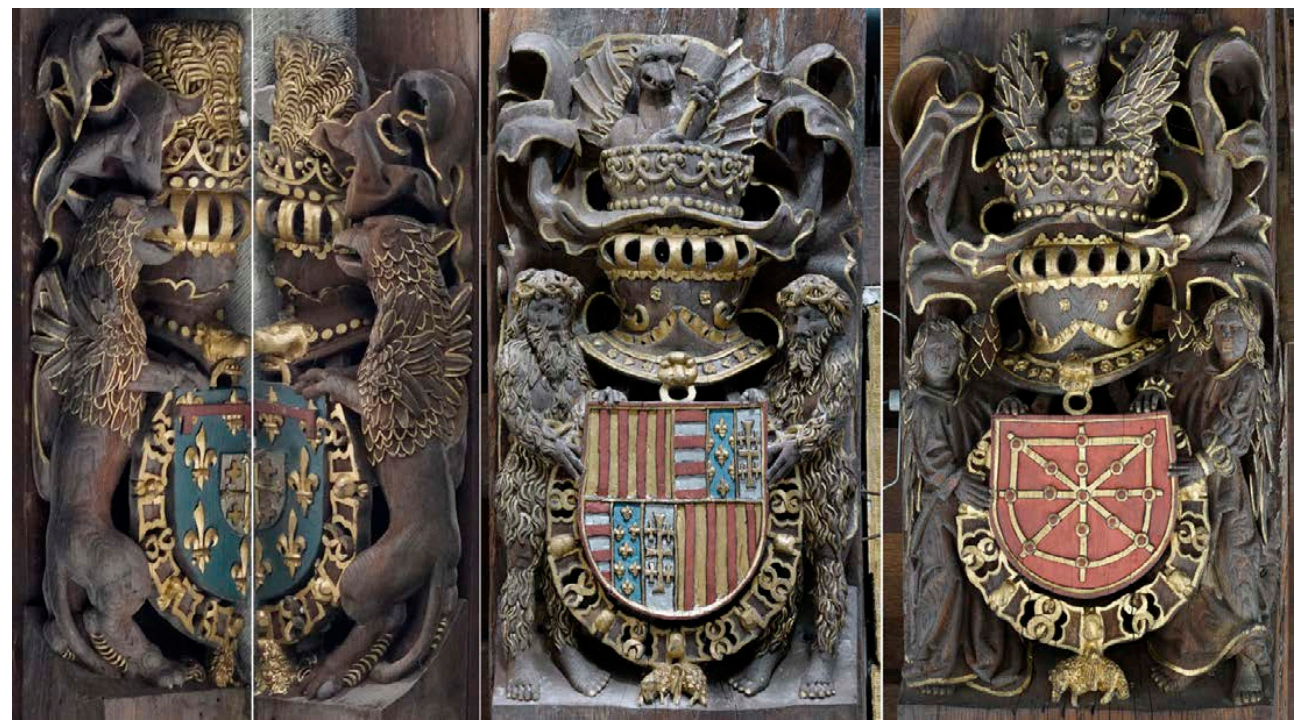

Fig. 7. Escudos de armas de Sicilia citra Pharum, Nápoles y Navarra. Georges de la Postelerie, Michiel Pieters. 1528. Volkszaal, ayuntamiento de Aldenarda

lucían en la vestimenta personal e identificaban los sitiales. Con Carlos V la heráldica que lo acompañaba era tan novedosa y abundante que manifestaba su poderío y su grandeza por sí misma. Los habitantes de Flandes estaban deslumbrados: el conde de Flandes era también imperator romanorum, dominador del viejo mundo y de las nuevas Indias descubiertas. La crisis abierta con la temprana muerte del conde Felipe el Hermoso se había resuelto de la forma más satisfactoria. Se entiende que se recurriera al armorial del emperador en la cámara de los regidores del Franconato de Brujas y en la volkszaal y schepenzaal de Aldenarda donde las insignias de los territorios hispánicos están muy presentes. Casi todos los territorios de las Nederlanden se encuentran en las salas: Flandes, Brabante, Güeldres, Limburgo, Lorena, Luxemburgo, Borgoña, Artois, Holanda, Zelanda y Henao -que se talló, pero no se ha localizado-. Son el grueso de lo que en 1548 se llamaron las Diecisiete Provincias. Falta Namur, Utrecht, Groninga, Overijseel y Frisia, aparte de las ciudades autónomas de Malinas y Amberes. También están presentes territorios fundamentales del Imperio y algunos complementarios, y trece reinos de las monarquías hispánicas en la Península o en Italia: España, Portugal, Castilla y León, Castilla, Granada, Burgos, Toledo, Navarra, Aragón, Valencia, Nápoles, Sicilia citra et ultra Pharum-vistas desde la Roma papal, al di qua e al di là del Faro de Messina.

Las armas de algunos escudos permiten sostener que el programa no tuvo un director heráldico pues, en algún caso, resulta un poco contradic- 
torio. Hemos visto que se buscaron dibujos aquí y allá. Tuvieron dudas e incurrieron en algún error. El escudo de España no contiene la Granada a pesar de que este reino se talló individualmente en la volkszaal. Al menos el amanuense que apuntó los pagos se refirió a las estrellas de Tirol-siempre efigiado con un águila explayada- que han de ser las de Zilly, ciudad que en los armoriales del Imperio alemán se presenta detrás o cerca de Cléveris, también elegida. El águila de Carniola carece de la cinta en media luna desplegada sobre el pecho. Mayor significación conlleva que el escudo de Sicilia citra Pharum exponga los viejos emblemas angevinos, cuando el territorio estaba completamente ocupado y gobernado por España desde 1501-1504. Tallaron las armas que utilizó Luis XII de Francia como rey de Nápoles: sobre campo azur, flores de lis con un lambel de tres pendientes en gules -Casa de Anjou- y un escusón con el blasón del rey de Jerusalén. Sin embargo, el escudo de Navarra es el definitivo del reino -conquistado por el rey Fernando en 1512 e incorporado a Castilla en 1515-, sin alusión alguna a los Evreux ni a los pretendientes franceses que sí se recogen en el armorial de Nancy, compuesto hacia 1535-1540 para Nicolas de Lutzelbourg, señor de Fléville

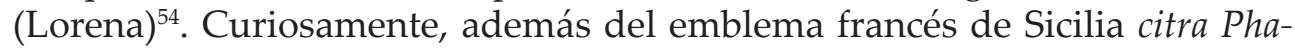
rum (que es como se había llamado tradicionalmente a lo que después se conoce como reino de Nápoles), se exponen en el mismo espacio de la volkszaal las insignias del nuevo reino de Nápoles tras la conquista del Gran Capitán, Gonzalo Fernández de Córdoba: un escudo cuartelado con las barras de Aragón en dos cuarteles alternos, combinadas con las de Hungría, Anjou y Jerusalén -las de la antigua Sicilia citra Pharum- terciadas en palo en cada uno de los otros dos cuarteles ${ }^{55}$. (Fig. 7)

54 Nancy, Bibliothèque Mediathèque, Ms. 1727, ff. 6 y 9; http://bmn-renaissance.nancy.fr/ items/show/1240 Nicolas de Lutzelbourg murió en 1547. Este armorial ofrece los emblemas de los pretendientes franceses, tanto para Navarra como para Sicilia citra Pharum.

55 Así se representó al reino de Nápoles en las ceremonias y armoriales imperiales; por ejemplo, en la pompa fúnebre de Carlos V - La magnifique et sumptueuse pompe funèbre faite aus obseques et funérailles du trèsgrand et trèsvictorieus empereur Charles cinquième, célébrées en la ville de Bruxelles le XXIX. jour du mois de décembre M.D.LVIII. par Philippes Roy catholique d'Espaigne son fils, A Anvers, de l'imprimerie de Christophle Plantin, 1559- y en el armorial de Vigil Raber, aunque en éste faltan las fajas de gules y plata alusivas al reino de Hungría que se habían incorporado a la Sicilia citra Pharum desde tiempos de Ladislao I; Vigil Rabers Sterzinger Wappenbüch, f, 1, Weimar, Herzogin Anna Amalia Bibliothek, http://bilderserver.at/wappenbuecher/VirgilRaberEXAv2_52z2/. Sobre la interpretación de las armas de Sicilia ultra Pharum no tiene duda porque desde finales del siglo XIII era de administración aragonesa: las armas de Aragón y dos águilas explayadas repartidas en un escudo cuartelado en aspa o sotuer. Así aparece en los armoriales, y en el Gran arco triunfal de Maximiliano (1515-1517) donde, sin embargo, Durero propuso para Sicilia citra Pharum un águila explayada tomada del viejo emblema de los Hohenstaufen. La heráldica de las dos Sicilias se mezclaba con las disputas políticas por el dominio territorial de Italia. Para el reino de Nápoles, también efigiado por Durero a continuación de las dos Sicilias, el pintor alemán dejó un escudo cuartelado sin rellenar que 
En las salas del consejo y de los regidores de Cortrique -raadzaal y schepenzaal-comenzadas unos años antes -de 1517 a 1527- la heráldica representada es local y tiene un desarrollo escaso, circunscrito a las chimeneas. En la raadzaal preside el emperador con la espada de la justicia y el orbe tripartito, pero la iconografía es tradicional. Con intención moralizante, a los magistrados se les recuerdan los pecados y sus consecuencias, las virtudes y sus beneficios, así como los ardides de unas mujeres y las acciones justas y caritativas de otras, escenas del Antiguo y Nuevo Testamento, los santos de devoción local y los beneficios de la piedad religiosa.

En Aldenarda escogieron un programa que ubica a la ciudad en el Imperio, una propuesta de interés internacional, de exaltación de la monarquía y del territorio. Como en Cortrique, donde las zapatas figurativas participan decisivamente en el relato, la heráldica imperial se desarrolla en grandes y visibles soportes de muy rica decoración. Este tipo de zapatas, con la misma función heráldica, se encontraba desde el siglo anterior en edificios públicos y religiosos; por ejemplo, en los palacios Watervliet y Bladelin de Brujas -con la heráldica de Felipe el Bueno, su esposa Isabel de Portugal y Pedro de Medici- o en la iglesia de Jerusalén, por citar obras anteriores de una misma localidad.

Escudos con timbre, y algunos con soportes, se iluminaron en los armoriales del siglo XV y principios del XVI. Los dibujaron miniaturistas y pintores, incluido Alberto Durero o Hans Burgkmair el Viejo. También se hicieron grabados con modelos y, más tarde, se imprimieron libros de armoriales ${ }^{56}$.

Se suele decir que durante la primera mitad del siglo XVI los escultores de la madera en Países Bajos, sobre todo los que se especializaron en la confección de retablos, fueron más tradicionales que los que tallaron alabastro, técnica en la que destacaron Conrad Meit, Jan Mone y Guyot de Beaugrant. Pero el panorama no se conoce bien y hubo artistas que, como Spierinck, desarrollaron un estilo de transición que no es ajeno a la nueva estilística llegada de Italia, bien sea por formación propia o porque colaboró en la policromía con escultores de la piedra. Además, la piedra usual en Países Bajos

tanto podía aludir a la heráldica francesa del territorio como a la aragonesa. Todavía hacia 1555 Virgil Solis dibujó la bandera de Nápoles con las flores de lis y el lambel; SOLIS, Virgil: Wappenbüchlein. Zu Ehren Der Römischen Kay. ond Kü. Mt., auch Bäbstlicher Heyligkeit, sambt anndern der Fürnemsten auslendischen Königreichen, Churfürsten, Fürsten ond gemeinen stennden ... Souil derselben Wappen ... mit Jren namen ond farben, Nürnberg, Solis, [1555].

56 Se relaciona con Israhel van Meckenem (c. 1440-1503) un grabado que reproduce un escudo de Cristo con los instrumentos de la Pasión. Lleva armas, tenantes y timbre semejantes a los empleados en Aldenarda; WOLFF, Martha, The Illustrated Bartsch. 23. German and Netherlandish masters of the fifteenth and sixteenth centuries, New York, Abaris Book, 1985, p. 111, nº 33(56). Los libros armoriales -wappenbuch- se hicieron populares en Alemania; el primero o uno de los primeros fue el del grabador Virgil Solis: SOLIS, Virgil, Wappenbüchlein..., s/p. 


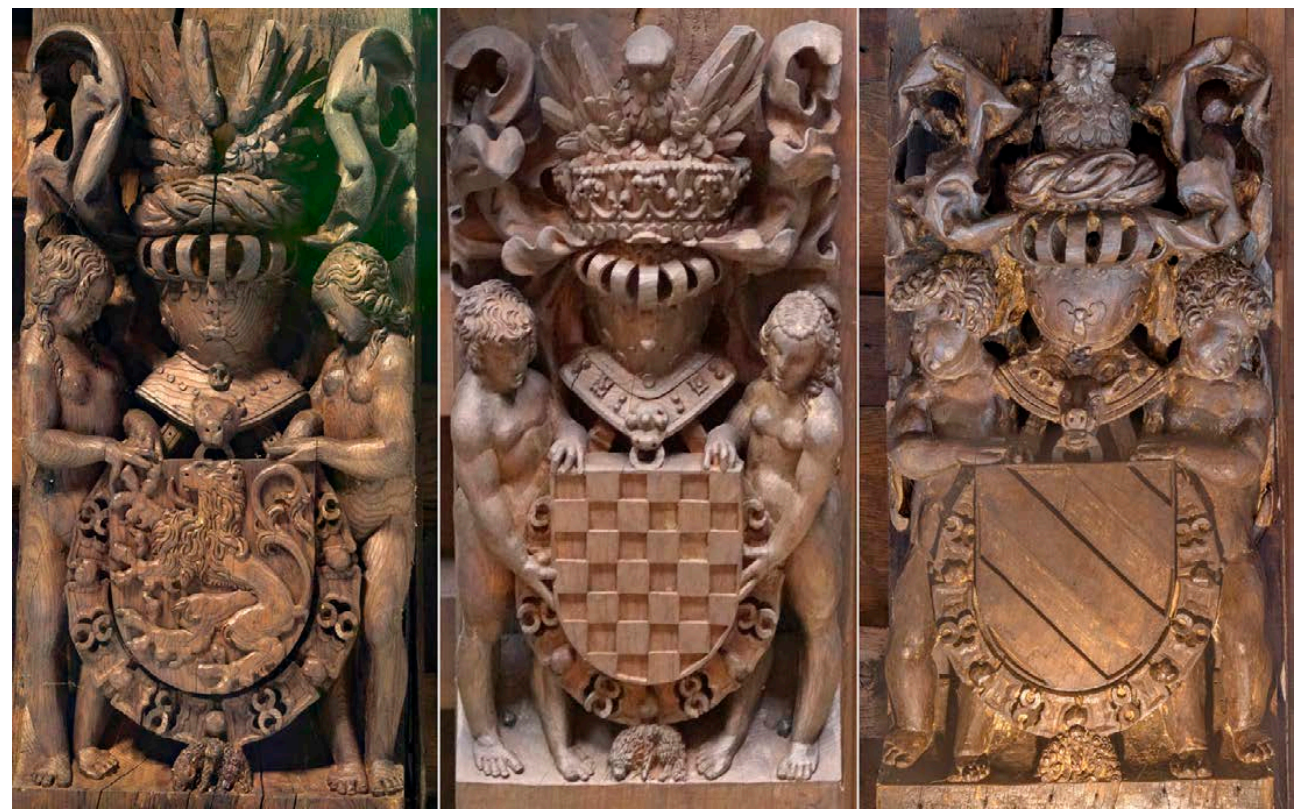

Fig. 8. Escudos de armas de Brabante, Croacia y Borgoña. Gillis Spierinck. 1528.

Segundo piso y schepenzaal del Ayuntamiento de Aldenarda

-sea el alabastro o la piedra de Avesnes- se trabajaba fácilmente con un instrumental de talla y pulido parecido al de la madera y no había motivo para que fueran actividades separadas ${ }^{57}$.

De las zapatas encargadas a Gillis Spierinck no se conservan ni Portugal, ni Cléveris, ni una mitad de Brabante, a menos que estén ocultas en el segundo piso por los armarios del archivo del siglo XVIII. El resto ha llegado en buenas condiciones y sólo encontramos pequeños deterioros y alguna recomposición: los soldados que flanquean el escudo de Güeldres, obra de Spierinck, se completan con pies de los salvajes tenantes de Zelanda, trabajo de Van der Schelden. Los escudos de Croacia, Borgoña, Güeldres y Ferrette son fáciles de identificar y nos descubren el estilo de Spierinck. Son suyas también las zapatas de Sicilia -Sicilia propiamente dicha o Sicilia ultra Pharum- y de Brabante. Spierinck coloreó los esmaltes de los territorios representados en la volkszaal, pero los de la schepenzaal y todos los del segundo piso han perdido el color o no se policromaron, lo que dificulta la identificación ya que, con esmaltes diferentes, Limburgo, Flandes, Brabante y Holanda compartían un león rampante. La identificación de los estilos de

57 Sobre el trabajo del alabastro, los dos tipos de piedras conocidas con este nombre en Países Bajos -un yeso y una calcita-, el instrumental de trabajo... LIPINSKA, Aleksandra, Moving Sculptures: Southern Netherlandish Alabasters from the 16th to 17th Centuries in Central and Northern Europe, Leiden/Boston, Brill, 2014, pp. 17 y ss. 


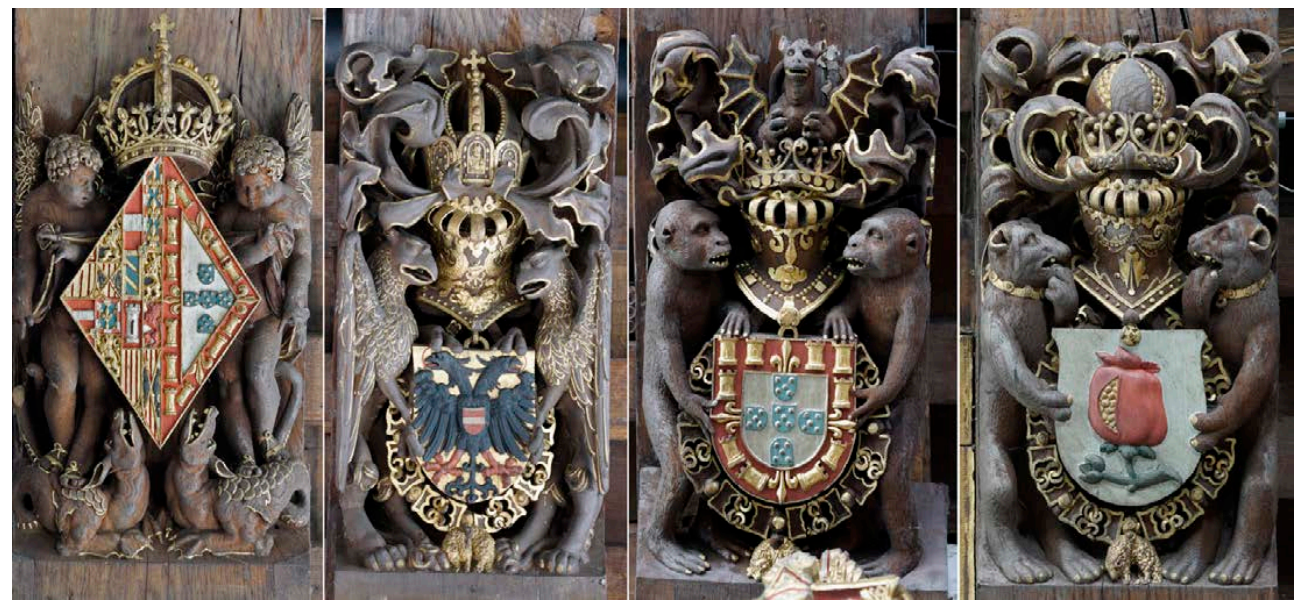

Fig. 9. Escudos de armas del emperador, Habsburgo, Portugal y Granada. Pauwels van der Schelden. 1528. Volkszaal, ayuntamiento de Aldenarda

los artistas permite proponer la correspondencia, en este caso para Brabante: dos muchachas desnudas y contrapuestas sostienen el escudo de Brabante en cuya cimera van dos alas de ave sobre el característico turbante del país.

Spierinck practicó un estilo moderno con un modelado corporal suave y relativamente natural en los desnudos que alcanza sus mejores logros en los niños tenantes de Borgoña y en el hombre y la mujer de Croacia (Fig. 8). Muy elaborado y efectista es el contrapposto de los dragones de Ferrette. En los soldados de Güeldres practica una talla profunda y angulosa al tener que representar una vestimenta acuchillada en mangas y pantalones. Consigue dos figuras bien expresivas, aunque se advierte un cierto grado de esquematismo y abstracción antinatural que fue frecuente en la talla de figuras pequeñas de los retablos brabanzones. Para los guerreros de Sicilia ultra Pharum vuelve al modelado suave y redondeado. Visten, en este caso, a la romana y lucen originales borgoñotas en lugar de las gorras de los lansquenetes de la zapata de Güeldres. Emplea en los lambrequines hojas muy carnosas que más parecen telas almidonadas con dobleces o, incluso, cueros.

Pauwels van der Schelden fue el más importante escultor de cuantos trabajaron en el ayuntamiento de Aldenarda. Se encargó de la escultura en piedra y, de las imágenes que estuvieron en el exterior, se conservan algunas figuras femeninas $\mathrm{y}$, al menos, un amorcillo -expresivo y cercano a los de Beaugrant en el Franconato de Brujas-. También, las tres imágenes de la chimenea de la schepenzaal. En las figuras emplea un estilo suave, elegante, clásico, bien modelado y sin apenas expresión. Compone las telas con pliegues naturales que evocan la Antigüedad, algo quebrados como es habitual en Países Bajos. Muy notable es la imagen de María con el niño que preside 
la chimenea de la sala de los regidores. La acompañan dos virtudes y de nuevo la heráldica protagoniza el programa ornamental. Se repiten las armas del Imperio, Flandes y Aldenarda tanto en la chimenea de piedra como en el portal de madera, donde se despliega un extenso repertorio all'antica, inspirado en los grabados de paneles decorativos italianos, o nórdicos a imitación de aquellos. En los frisos del portal y en algunos compartimentos de las puertas se insertan bustos y tondos de emperadores. Con los roleos de acanto y la vegetación metamorfoseada utilizada translitera grabados renacentistas. Hemos visto, además, que se buscaron modelos en el castillo de Zottegem. También constan pagos a Van der Schelden por dibujos y patrones para las figuras a trabajar con piedra de Avesnes ${ }^{58}$.

En las zapatas, están suavemente compuestos en simetría lateral los dragones de Habsburgo, los osos de Granada, los monos de Portugal, los felinos de Carniola; todos correctos, con poca alma. Notables nos parecen los salvajes de Zelanda y magníficos, los niños del escudo de Carlos V e Isabel de Portugal que es una composición original muy cuidada y de acabado delicado, tanto en los tenantes como en los dragones situados a los pies. Los toques de oro y plata -sobre todo el matizado reparto del gris-, contribuyen a modular el volumen y la luz. Este dorado parcial, obra de Spierinck, añade una nota de sofisticación ${ }^{59}$. Se trata de la pieza más sobresaliente del conjunto y, por el estilo, parece haber contado con ayuda decisiva de Georges de la Postelerie. (Fig. 9)

De Georges de la Postelerie se conservan tantas zapatas como cobró. Sus obras son perfectamente identificables al señalarse que hizo la zapata de España entre dos unicornios. En los grifos de Sicilia citra Pharum y en los osos de Valencia siguió a Pauwels; en el resto, también, pero el resultado ofrecido es extraordinario con tenantes en contrapposto muy elegante, como en ningún otro autor. Son magníficos los unicornios de España, las jóvenes de Kiburgo, los soldados vestidos a la romana de Holanda y los niños de Aragón y de Brabante -de nuevo el turbante del timbre asegura su identificación-. En todos los casos los lambrequines son telas al viento. Los adornos renacentistas en los yelmos son los más avanzados que se pueden encontrar en este programa. Consiguió tan logradas obras como Van der Schelden e, incluso, superiores. Es muy probable que sea prácticamente suyo el escudo de la pa-

58 VAN LERBERGHE, Lodewyk y RONSSE, Jozef, “Documenten..., pp. 389 y p. 393 donde se apuntó el precio de la piedra de Avesnes adquirida para esculpir los amorcillos de las grandes ventanas abiertas en el tejado.

59 Semejante sistema de dorado de los perfiles y plateado matizado se emplea en la policromía de las demás zapatas de la volkszaal -zapatas del emperador, Flandes, Portugal, España, Aragón, Castilla y León, Castilla, Granada, Valencia, Navarra, las dos Sicilias y Nápoles-, pero la más delicada intervención se aplicó en el escudo de Carlos V e Isabel de Portugal. 

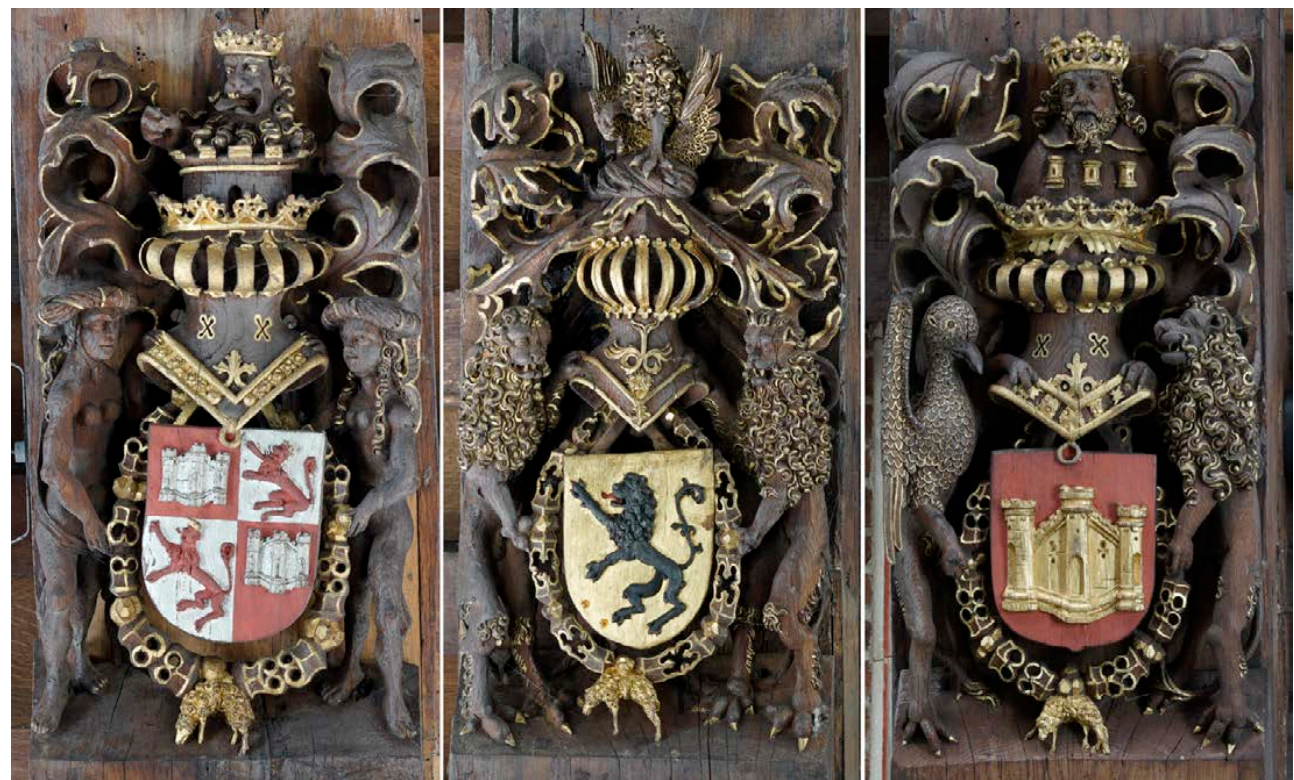

Fig. 10. Escudos de armas de Castilla-León, Flandes y Castilla. Adriaen van Hoorick.

1528. Volkszaal, ayuntamiento de Aldenarda

reja imperial, una obra maestra. La blandura del modelado o el modo de tallar el cabello es el mismo que se ve en sus obras seguras. También ha de ser suya la zapata de Burgos, con soldados romanos de magnífica talla de nuevo. El yelmo, con un rostro metamorfoseado, está tomado de los paneles decorativos italianos. (Fig. 4 y 7 )

Muy distintas son las formas que utilizó Adriaen van Hoorick, cantero y escultor colaborador habitual de Willem de Ronde, Cornelis van Pede y Pieter Wayback con los que formaba el equipo ${ }^{60}$ encargado de la decoración secundaria y de toda la vegetal del edificio. Practicó un estilo tardogótico, de figuras alargadas con cuerpos de anatomía convencional sin interés por el modelado y el naturalismo del nuevo arte: lo confirma el esquematismo de los pechos, y del cuerpo en general, en las muchachas tenantes del escudo de Castilla y León. Los rostros se animan con una ligera sonrisa igualmente convencional. También entre los escultores de la piedra había practicantes de las formas tradicionales del Tardogótico. Siendo un autor diferente, su estilo se asemeja mucho al del que labró las zapatas de la raadzaal de Cortrique. Todas las zapatas identificadas -Flandes, Castilla y Castilla y León- están policromadas y se localizan en la volkszaal, indicio de que estaba muy bien considerado, aunque resulte tan tradicional. De su mano era la escultura de María en el primer cuerpo del beffroi. (Fig. 10)

60 VAN LERBERGHE, Lodewyk y RONSSE, Jozef, “Documenten..., p. 373. 

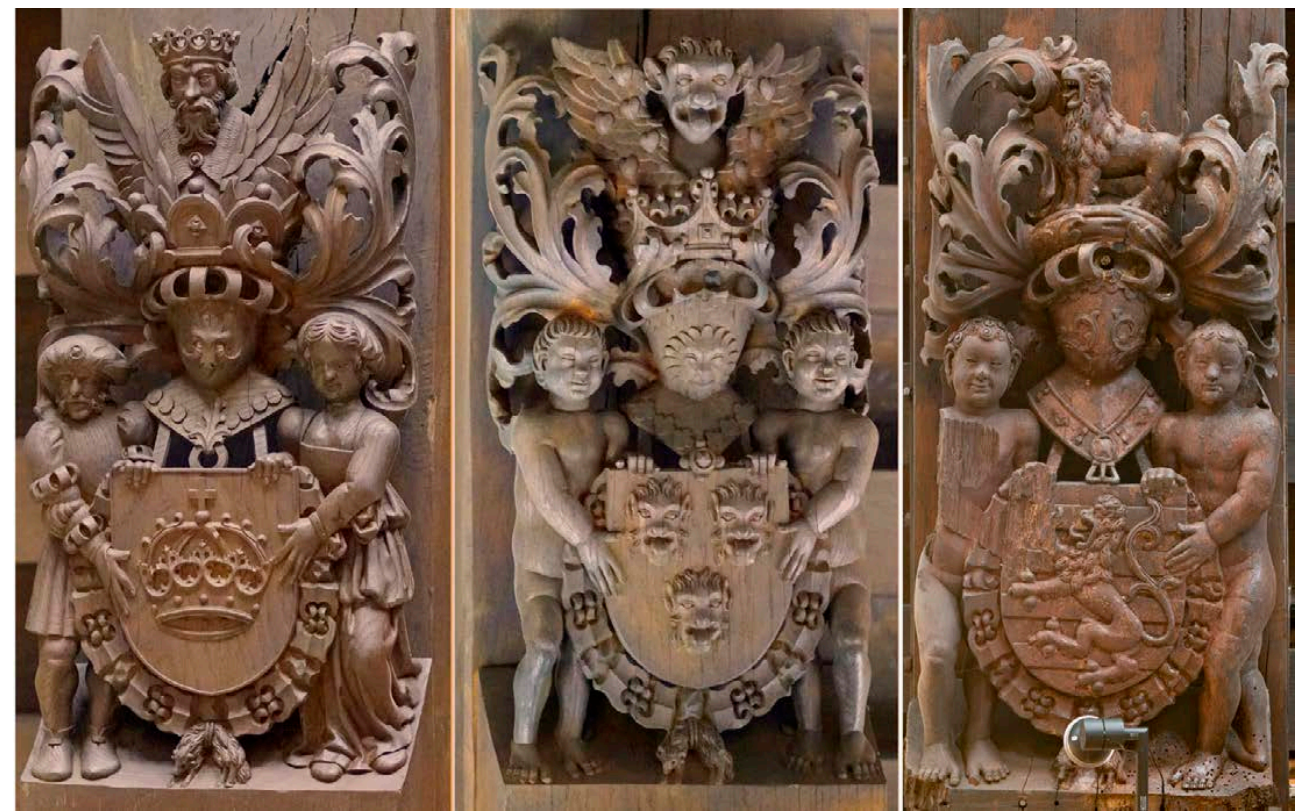

Fig. 11. Escudos de armas de Toledo, Dalmacia y Luxemburgo. Joseph de Clercq. 1528.

Schepenzaal, ayuntamiento de Aldenarda

Las zapatas labradas por Michiel Pieters -Nápoles, Navarra, Artois, Austria, Flandes, las dos mitades de Zilly y la mitad de Tirol- también demuestran su apego a las formas del Gótico flamenco: rostros en calma un tanto alargados, pliegues profundos en uve, figuras estilizadas tomadas de la pintura del país del siglo anterior -véanse los ángeles tenantes de Navarra-, los salvajes característicos del Tardogótico. Las muchachas que acompañan la insignia de Artois visten sandalias con adorno renacentista, pero el detalle es rudo. Los leones de la zapata de Flandes y los felinos de Austria lo vinculan a la obra de Pauwels, pero como un colaborador de formación tradicional; basta confrontar el tradicionalismo de los salvajes de la zapata de Nápoles con el intento de modernidad de los tallados por Van der Schelden en la de Zelanda; o comparar los pliegues angulosos en la piel de los leones en el escudo de Flandes con el suave modelado redondeado de los que Pauwels labró en las armas de Carniola. (Fig. 7)

Joseph de Clercq fue un escultor virtuoso y contradictorio. Es el único que recurrió a la cardina gótica para los lambrequines de todas sus zapatas: Toledo, Dalmacia, Luxemburgo, Estiria y Eslavonia -las dos últimas en mitades-. Siendo tradicional, en las figuras fue sensible al nuevo arte. Modeló y compuso con mucha habilidad; nos parece un verdadero imaginero. Hizo esculturas de volúmenes corpóreos, un poco anchas y muy bien modeladas. 
El vestido de la mujer tenante de las armas de Toledo se pliega acompasado con el movimiento del cuerpo. Los rostros de los faunos de las armas de Windische Mark -por Eslavonia- tienen una gran potencia expresiva. Sus cuerpos -adiposos y de hombre sin pelo hasta el arranque de las rodillas, aunque se trata de sátiros- son de piel suave y natural: pretende seguir los nuevos estilemas italianos, pero los conoce insuficientemente. Con un modelado semejante trabaja los niños de las armas de Dalmacia y Luxemburgo. Todas las zapatas utilizadas en la schepenzaal, el espacio más exclusivo del ayuntamiento, son de De Clercq, si se exceptúa la de Croacia, que es de Spierinck, Por su extraordinaria semejanza con la zapata de Luxemburgo se le debe adjudicar el escudo de Austria que va terciado en faja con el esmalte perdido. Puede ser la zapata que se le abonó sin identificación, distinta de otra de Austria pagada a Pieters y también conservada. Los eslabones de la cadena del Toisón, todo el timbre y, sobre todo, las cimeras son tan exactas en ambas zapatas que permiten suponer que, como en España, en los talleres se utilizaba algún sistema de traslado de puntos para asegurar un resultado conveniente y, a la vez, economizar y agilizar el trabajo. En la misma dirección apunta la similitud que tienen entre sí los timbres de las zapatas de Pieters: los de Nápoles con Navarra y los de Flandes con Artois.(Fig. 11)

\section{Arnaut Spierinck / Arnao de Bruselas en Zaragoza y la infor- MACIÓN DE SU TESTAMENTO}

El salón público del ayuntamiento de Aldenarda exaltaba las insignias de los reinos peninsulares -España, Castilla y León, Aragón, Navarra y Portugal-y aún equiparaba, en las zapatas de la techumbre, los reinos de Flandes, Nápoles y el Imperio con Valencia y Granada allí presentes. En Flandes, un territorio vinculado tradicionalmente con Francia, a nadie se le ocultaba que, en el triunfo del emperador Carlos V sobre las pretensiones francesas, había sido decisivo el poder de España. El atractivo de este país, en el imaginario individual y colectivo de Países Bajos, hizo que centenares de artesanos de Países Bajos se dirigieran hacia la Península desde que el conde de Flandes y duque de Brabante, Felipe el Hermoso, se desposara con Juana de Castilla y Aragón. El flujo de inmigrantes -de todos los oficios imaginables- aumentó en paralelo con el éxito militar de los españoles en Italia y culminó con la toma de posesión de los reinos peninsulares por Carlos de Gante, la elección imperial y su coronación posterior en Bolonia.

Arnao aparece en la documentación de Zaragoza el 10 de septiembre de $1536^{61}$. Poco antes acababan de concluirse las obras del ayuntamiento de Aldenarda. Allí había trabajado Gillis, nombre coincidente con el que dijo

61 MORTE GARCÍA, Carmen y AZPILICUETA, Miguel, “Arnaut de Bruselas..., pp. 65-68. 


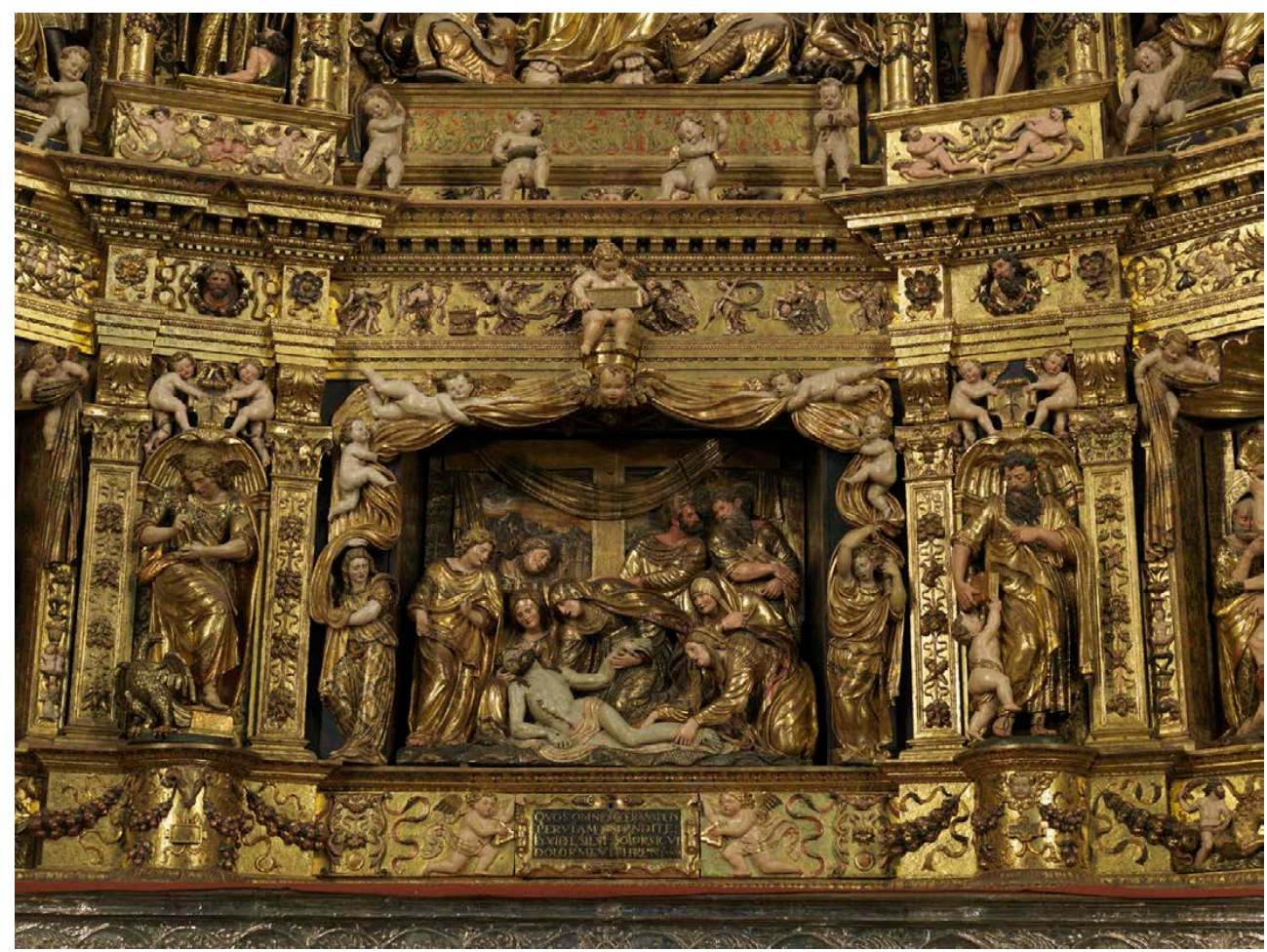

Fig. 12. Retablo mayor de Santo Domingo de la Calzada, detalle con angelitos. Damián

Forment y su taller. 1537-1540. Catedral de Santo Domingo de la Calzada

era su hermano avecindado en Bruselas. Las obras las habían dirigido arquitectos bruselenses. Gillis, que tuvo una intensa actividad como hemos visto, consta que viajó a Bruselas y a otros lugares para tomar modelos. Es muy probable que contara con el beneplácito de los maestros de obra y, si acertamos en la relación propuesta, sería un miembro del equipo de estos ya que policromó las ventanas, la crestería y las figuras; de modo que su intervención hubo de ser decisiva para el aspecto final del edificio, muy distinto del que hoy día presenta. Ciertamente en 1512 está documentado un primer Spierinck en Aldenarda, pero se desconoce de dónde era residente y se sabe que a esta ciudad llegaron bastantes artistas de Bruselas, primero a las obras de Santa Walburga y después a las del ayuntamiento, ambas dirigidas por arquitectos bruselenses ${ }^{62}$.

62 Años más tarde, en 1569, consta la presencia en Aldenarda de Jooris Spierinck, de Bruselas; VAN LERBERGHE, Lodewyk y RONSSE, Jozef, "Documenten..., p. 101. En 1555 un Jacques Spierinck fue condenado por la justicia (p. 19). Son los dos únicos Spierinck que hemos localizado en la segunda mitad del XVI en los seis tomos documentales de la publicación citada. 
Hemos visto que los estilos de los imagineros de la madera en Aldenarda son más evolucionados que lo que se observa en Cortrique, cuyas zapatas y chimeneas se tallaron un poco antes. Con las obras del ayuntamiento llegó el influjo del nuevo estilo que en el entorno de Bruselas y Malinas estaban desarrollando Jean Mone, Conrad Meit y Guyot de Beaugrant. Un nuevo estilo imperaba en el arte europeo y contaba con la protección de Carlos V. Los regidores eran conscientes e hicieron un gran esfuerzo por visitar obras modernas -el castillo de Zottegem, por ejemplo- y copiar modelos ornamentales. La arquitectura del ayuntamiento es decididamente tardogótica, pero la mayor parte de la escultura resulta más moderna.

En cualquier caso, fuera de la obra de los grandes escultores del círculo imperial, la escultura de los talleres de Aldenarda muestra el estado de desarrollo de la talla de la madera hacia 1535 y sus limitaciones, en el momento que Arnao es documentado en Zaragoza. Una escultura lígnea más evolucionada, en las imágenes y en lo ornamental, que la dominante en los talleres de retablos. Un estilo influido por la gran estatuaria trabajada en piedra. Van der Schelden talló en ambos medios y con él colaboraron De la Postelerie y Spierinck, al menos tan acertados como él en el trabajo de la madera. En este taller se recurrió a paneles ornamentales de procedencia italiana o a grabados locales que los imitaban. El repertorio desplegado en el portal de la schepenzaal es un verdadero libro o tratado de ornamentación all'antica.

Entre las imágenes más logradas destacan los amorcillos de estos tres imagineros. Puede no ser casualidad que el retablo de Santo Domingo de la Calzada esté poblado de angelitos desnudos: los amorcillos del portal y de los tejados de Aldenarda. Una legión de angelitos y amorcillos se localizan en otras obras del ámbito de Arnao, aunque también se debe considerar el papel que les cupo a Guyot y Juan de Beaugrant en la difusión y el éxito de estas imágenes presentes en las tumbas del panteón de Nájera, y en los retablos de Genevilla, Lapoblación, Alberite, San Vicente de la Sonsierra, Ábalos, Elvillar de Laguardia, Logroño...

Hemos visto que en Aldenarda las esculturas al exterior se policromaron y al escultor Arnao de Bruselas hemos adjudicado las figuras del panteón de Nájera que están talladas en blanda piedra arenisca revestida de policromía para conseguir una apariencia más rica y evitar el deterioro de la piedra por la humedad" ${ }^{63}$. El contrato obligaba a dar blanco a las esculturas "en manera de alabastro", una técnica de policromía pétrea inusual y sin tradición local que también empleó Guillén de Holanda. Se perseguía mejor apariencia y mayor resistencia a la erosión. Gillis Spierinck se encargó de algo semejante

63 BARRÓN GARCÍA, Aurelio Á., “La galilea y el panteón real de Nájera: Juan Martínez de Mutio, Alonso Gallego y Arnao de Bruselas", BSAA arte, 84 (2018), p. 106. 
en Aldenarda: policromar y aumentar la durabilidad de las imágenes trabajadas en la blanda piedra de Avesnes. (Fig. 12)

\section{1. El taller de Forment y el aprendizaje de Arnao de Bruselas}

Por el tipo de contrato que firmó al entrar en el taller de Forment, se puede asegurar que Arnao Spierinck conocía la talla de la madera y nada tenía que ver con el joven que, sin conocimiento alguno, entraba por primera vez en un taller para aprender un oficio con el que ganarse la vida. El sistema de trabajo que tenía establecido Forment hace que sea difícil observar las distintas manos participantes en sus contratos. Sin embargo, permite conocer el grado de especialización que tenían unos y otros cuando entraban en su taller. Para abaratar costes y maximizar las facultades de los distintos oficiales y aprendices, las piezas se trabajaban en fases que pasaban de unas manos a otras conforme aumentaba la complejidad y la delicadeza del trabajo a ejecutar. Por ello, cuando contrataba aprendices u oficiales establecía las labores que habrían de realizar.

Disponemos de dos contratos separados por unos días con los que dos "aprendices" ingresaron en Zaragoza en el taller del valenciano. El 31 de agosto de 1536 firmó primero Francisco Navarro, natural de Ávila, lo que permite sospechar que, aun siendo mozo menor de 25 años, tenía cierta edad y posiblemente conocimientos en el arte de la escultura pues se sabe que al obrador de Forment vinieron varios artífices a completar su formación. Francisco entró por tres años. Durante el primer año y medio únicamente debía "limpiar" todo aquello que le confiara el maestro. En la segunda mitad del contrato podría "desbastar y acabar de todo punto" las obras que el maestro le permitiera. Habían acordado, además, que Forment le mantuviera en su casa alojado y alimentado y que le abonara 300 sueldos jaqueses -es decir, cien al año- para vestirse y calzarse. Además, el maestro le debía comunicar sus conocimientos - "demostrarme la... vuestra arte de imaginero"-. Para asegurar el servicio y evitar la fuga del aprendiz, Forment le hizo declarar que tenía una comanda o préstamo de 100 ducados que se obligó a devolver ${ }^{64}$.

El contrato que Arnao firmó, declarándose también mozo, fue mucho más exigente, ya que Forment debía conocer la habilidad del brabanzón con la escultura. Como Navarro, el 10 de septiembre de 1536 firmó un contrato de aprendizaje, aunque sospechamos que debía haber sido de oficialía. Las cláusulas sobre alojamiento, comida y salario para vestirse y calzarse

64 MORTE GARCÍA, Carmen y AZPILICUETA, Miguel, “Arnaut de Bruselas..., pp. 67-68. MORTE GARCÍA, Carmen, Damián Forment..., pp. 433-435, doc. 406. Véase que el notario no certificó que los 100 ducados se entregaran, sino que el aprendiz declaró tener una comanda que se obliga a devolver. A continuación, Forment se obligó a no demandar la comanda salvo en incumplimiento de contrato. 
son iguales -en este caso 400 sueldos porque el contrato se firmó por cuatro años, lo que nos informa, en teoría, que no había cumplido 21 años ya que la mayoría de edad se alcanzaba a los 25 años, aunque para un extranjero no había modo de certificarlo ${ }^{65}$. Para asegurarse que Spierinck no se iría a otro lugar ni a otro taller, se duplicó la cifra que el supuesto aprendiz declaró que había recibido y que tendría que devolver si incumplía alguna cláusula: 200 ducados, una barbaridad. Pero la diferencia mayor entre ambos contratos se encuentra en las labores comprometidas. En lugar de "limpiar" durante la mitad del contrato, desde el primer día y durante dos años habría de "obrar" lo que Forment le quisiera pedir. Durante el tercer año tendría que "desbastar y acabar" las obras que hubiera. Es decir, desbastar o eliminar lo sobrante (basto y grosero) hasta conseguir el bulto general y prepararlo para el trabajo de la talla propiamente dicha, y acabar las piezas, que entendemos se refiere a pulirlas y prepararlas para recibir la policromía después de que las tallara el maestro u otro colega más experto o de mayor confianza de Forment. A diferencia del abulense cuyo contrato únicamente preveía las labores comentadas hasta ahora, el bruselense podría durante el cuarto año "rebotar y desbastar" las obras ${ }^{66}$, únicamente de septiembre de 1539 a septiembre de 1540, si se cumplía la letra del contrato. Según entendemos, sólo entonces podría tallar las imágenes en el proceso final y tendría acceso al sistema de traslado de puntos que se utilizaba en este taller zaragozano. Circunstancia que permitió al valenciano acometer tantas obras y entregarlas a tiempo y con un acabado tan regular y uniforme.

En la preparación de una escultura, el primer paso consistía en transformar los dibujos, muchas veces tomados de grabados, en modelos volumétricos. Saber trasladar los dibujos y grabados a modelos en barro o yeso era una de las habilidades que se aprendían en los talleres de los escultores. En los talleres se trabajaba con modelos que se trasladaban a las obras finales mediante sistemas diversos de medir y sacar puntos $\mathrm{y}$, a nuestro parecer, esta labor fundamental es la que se denominaba rebotar: una talla ayudada de procesos e instrumental mecánico. En el inventario del escultor burgalés Antonio de Elejalde, que heredó el taller de Diego Guillén, primer contratista del retablo de Santa Clara de Briviesca, se mencionan junto a varios libros y papeles de estampas o grabados, y ocho trazas en pergamino: modelos de partes del cuerpo humano en yeso, instrumentos necesarios en la talla-como gubias, formones, cinceles, mazos, barriletes, escoda, azuela, garlopas, ce-

65 Sobre la situación de los menores de edad en los oficios, BARRÓN GARCÍA, Aurelio Á., "Primeras obras en La Rioja del arquitecto Juan de Rasines, 1469-1542", Boletín del Museo e Instituto Camón Aznar, 110 (2012), pp. 8-15.

66 MORTE GARCÍA, Carmen y AZPILICUETA, Miguel, “Arnaut de Bruselas..., p. 68. MORTE GARCÍA, Carmen, Damián Forment..., pp. 435-436, doc. 407. 
pillos-, "quatro bancos para labrar" -creemos que algunos podrían ser una suerte de cepo con elementos de sujeción de bloques de madera para la talla, como los que se usaban en la escultura desde el siglo XV al menos; así se entiende que se destacaran "bisagras" o "cierres"-, y algunos compases y posibles instrumentos de traslado de puntos -"dos conpases y unas tenasas grandes y dos barrenos"-, además de otros para reproducir molduras ${ }^{67}$.

Damián Forment conseguía con un sistema de trabajo como el descrito -en el que se distribuye el desbastado, el rebotado y el pulido- una considerable uniformidad en el resultado final que limita la aparición en superficie de la mano personal de los artistas intervinientes. Además, debían seguir dibujos y modelos ${ }^{68}$ del maestro, pues podemos sospechar que esa era la tarea principal de Forment: la dirección de la obra, la conclusión de algunas imágenes significativas y la provisión de dibujos y $\operatorname{modelos}^{69}$, aunque mu-

67 BARRÓN GARCÍA, Aurelio Á. y RUIZ DE LA CUESTA, Mํㅗㄱ Pilar, “El escultor Antonio de Elejalde (1566-1583)", Estudios Mirandeses, 14 (1994), pp. 145 y 158-159. Un banco de trabajo con un bloque de madera sujeto en proceso de tallado se ve en un grabado de Georg Pencz de 1533 titulado Los hijos de Saturno; también en otro de Sebald Beham que representa al planeta Mercurius y es de 1539. Se reproduce uno de estos bancos de escultor en el Landesmuseum Württemberg de Stuttgart. Véase, DAUSSY, Stéphanie Diane, Sculpter à Amiens en 1500, Rennes, Presses Universitaires de Rennes, 2013, pp. 45-69 y 83-109; GUILLOT DE SUDUIRAUT, Sophie, Dévotion et séduction. Sculptures souabes des musées de France vers 1460-1530, Paris, Musée du Louvre - Somogy editions d'art, 2015, pp. 36-52; CHAPUIS, Julien, “Escultura alemana: creación y percepción", en Últimos fuegos góticos. Escultura alemana del Bode Museum de Berlín, Valladolid, Ministerio de Educación Cultura y Deporte, Subdirección General de Documentación y Publicaciones, 2016, pp. 22-24. Del Río ha estudiado los sistemas de reproducción de esculturas del taller de Bigarny y propone la presencia de un definitor al modo que lo describe Alberti años antes de que se reprodujera en la edición italiana de 1568, RÍO DE LA HOZ, Isabel del, El escultor Felipe Bigarny (h. 1470-1542), Valladolid, Junta de Castilla y León, 2001, pp. 344-348. Se reproduce por primera vez el diffinitore en, ALBERTI, Leon Batista, Opuscoli morali, Venetia, appresso Francesco Franceschi, Sanese, 1568, "Della Statua", p. 299 (ed. Cosimo Bartoli). También Vasari describió en Las vidas un sistema de traslado de medidas a diferentes escalas mediante escuadras y plomadas.

68 En las obras de Forment es fácil observar resultados similares obtenidos en distintas imágenes del retablo. Así se comprueba en el de Santo Domingo de la Calzada por haber utilizado un mismo modelo. Podemos verlo en la pierna semiflexionada de las figuras de Santo Domingo de la Calzada, San Pedro, San Andrés y Santiago. En posición inversa se encuentra en las imágenes de San Pablo, San Matías, San Felipe, San Bernabé, Malaquías, así como en el rey Gaspar de la Adoración de los Magos o en uno de los pastores en la otra Adoración. El mismo modelo sin vestimenta, en el profeta Baruch (Barac) y en Manue (Manóaj).

$69 \mathrm{Al}$ contratar Forment un retablo para Sallent de Gállego, el 30 de enero de 1537, se le exigió "que todos los cartones que an de serbir para las ystorias que se an de pintar en el dicho retablo sean debuxadas de su propia mano", aunque la realización y pintura se concertó ese mismo día con Juan de Moreto y con los pintores Martín García y Antón de Plasencia; HERNANSANZ, Ángel, MIÑANA, María Luisa., SARRIÁ, Fernando, SERRANO, Raquel y CALVO, Rosalía, "Juan de Moreto y Martín García: obras de colaboración (1530-1541)", Seminario de Arte Aragonés, 42-43 (1990), pp. 358-363 y 372-374. 
chas veces procedieran de grabados. Con los años, Arnao Spierinck acabó instalando un taller semejante en Logroño ${ }^{70}$-seguramente que no tan rígido ni tan productivo-. Lo heredó Juan Fernández de Vallejo, primer gran maestro español del foco logroñés.

Como Arnao entró en el taller de Forment poco después de que concluyeran las obras del retablo de Teruel, se podría pensar que ambas circunstancias pudieron estar relacionadas y que el "afrancesamiento" del posterior estilo del brabanzón se produjo en contacto o conocimiento del taller de Joly. Sin embargo, creemos que lo más probable es que Spierinck acabara de llegar. Hemos insistido en cómo se presentó en el contrato de aprendiz: "Yo Arnaut de Bruselles, natural de la ciudad de Bruselles de la tierra de Brabant de Flandes"; aún no había adoptado un nombre adaptado al español. Nos parece que el extraordinario desarrollo de su arte es fruto de la inicial entrada en el obrador de Forment.

Sin poder obtener consecuencias firmes, por ausencia de la necesaria relación documental, al estudiar el retablo de Santo Domingo de la Calzada, así como el grupo de la Dormición del Museu Nacional d'Art de Catalunya o directamente los apóstoles de Genevilla se han comparado personajes de las tres obras citadas con algunos rostros del retablo de Teruel, labrado por Joly de 1532 a 1536, y se ha evocado el nombre de Arnao ${ }^{71}$. A nosotros nos parece que Juan de Beaugrant, que talló tipos más fuertes que los de Spierinck, pudo ayudar a Damián Forment en la labra de los apóstoles de la Dormición procedentes de la iglesia de San Miguel de Barcelona y fechados entre 1534 y 1537.

Sorprende que un escultor brabanzón de la madera, que se encontraba en Zaragoza en fecha tan temprana, acabara practicando un estilo que combina los estilemas característicos de lo francés con un intenso influjo italiano, directamente miguelangelesco en muchas de sus composiciones ${ }^{72}$. $\mathrm{Si}$, como proponemos, se formó en el taller de su posible hermano Gillis Spierinck en Aldenarda y en contacto con el taller de Van der Schelden y la

70 BARRÓN GARCÍA, Aurelio Á., "Juan Fernández..., pp. 35-58.

71 ECHEVERRÍA GOÑI, Pedro Luis y ORBE SIVATTE, Asunción de, "El retablo de San Esteban. Estilo e iconografía", en VV.AA., Renacimiento y Humanismo en Navarra. El retablo de Genevilla, Pamplona, Gobierno de Navarra - Institución Príncipe de Viana, 1991, p. 26; YEGUAS I GASSÓ, Joan, L'escultor Damià Forment a Catalunya, Lleida, Universitat de Lleida, 1999, pp. 75-88; MORTE GARCÍA, Carmen, Damián Forment..., pp. 323-326.

72 Weise apreció la relación de los apóstoles de Genevilla con la obra de Arnao de Bruselas en el retablo de Alberite, sobre todo con el santo titular, pero no se inclinó por asociar a Arnao de Bruselas con Genevilla -en su tiempo no se conocían las noticias documentales de Arnao en Genevilla- porque le parecía inusual que un neerlandés estuviera influido por Berruguete; WEISE, Georg, Die Plastik der Renaissance und des Frühbarock im Nördlichen Spanien. Aragón, Navarra, die Baskischen Provinzen und die Rioja, Tübingen, Hopfer-Verlag, 1957, p. 71. 
obra de Georges de la Postelerie, vino con un bagaje de considerable modernidad, aunque alejado del estilo de las grandes esculturas que realizará en España.

De la gubia de Arnao salieron rostros italianizantes de perfil romano con los ojos abiertos y tomados directamente de grabados de la obra de Miguel Ángel. Destacan sobremanera los apóstoles de Genevilla, las esculturas del trascoro de la Seo de Zaragoza -de una nobleza romana sin igual- o las figuras del ático del retablo de Santa María de Palacio en Logroño. En Aldenarda pudo ver cómo para los amorcillos dispuestos en el tejado o en el portal de la schepenzaal se recurrió a los putti grabados por Marcantonio Raimondi a partir del adorno de la Farnesina de Rafael -la Loggia di Psiche y las salas del Fregio y de Galatea- y a los grabados de Sebald y Barthel Beham. En el taller de Forment hubo de ver el recurso a las estampas de Durero. Como maestro independiente, Arnao incorporó composiciones de Miguel Ángel difundidas por diversos grabadores.

Junto a tipos fuertemente influidos por la estética de la Antigüedad, talló otros rostros más abstractos y esquemáticos de facciones muy delicadas, con los ojos pequeños, semicerrados y rasgados, y con una tendencia general -también en las figuras del primer grupo- a las expresiones entristecidas, melancólicas o directamente llorosas. Son ejemplos de esta vertiente, San Esteban de Genevilla, Santa Coloma de Angostina (Álava) o la María en la Presentación del retablo de Palacio en Logroño. Entendemos que son manifestación de su formación en Bruselas, en la que existían talleres tradicionales especializados en la talla de retablos y en la que algunos artífices competían en la expedición de las llamadas muñecas de Malinas.

Sin embargo, este tipo de obras no lo hemos encontrado en el ámbito de Gillis, aunque es cierto que ha desaparecido el retablo de Nokere y únicamente sabemos de él por las zapatas del ayuntamiento de Aldenarda. Lo mismo tenemos que decir sobre la preferencia que manifestó Arnao por los tipos humanos de complexión fuerte, aunque menuda.

No se suele destacar que Arnao Spierinck no sabía escribir cuando entró al servicio de Forment y que los únicos documentos encontrados que están signados por el escultor son los referidos al trascoro de la seo zaragozana ${ }^{73}$. Su escritura dista mucho de la bella caligrafía de Juan y Guyot de Beaugrant. Es seguro que vino de Bruselas con las habilidades prácticas de un consumado imaginero, pero carecía de cualquier formación que no fuera visual o manual. Por tanto, al aprendizaje brabanzón, a la facilidad natural que manifestó y a su infinita capacidad de asimilación se ha de sumar el contacto en España con los talleres con los que colaboró: los de Forment, Juan de Goyaz y los Beaugrant. Esto transformó al virtuoso artesano, que seguramente era

73 Véase arriba la nota 6. 
al llegar a la Península, en un consumado artista, pero no es el lugar, ni existe espacio, para comentar más detenidamente esta aventura.

\section{2. El pleito por el retablo de Santa María de Palacio en Logroño}

En La Rioja, Spierinck trabajó en el retablo mayor de Santo Domingo de la Calzada contratado por Forment. Colaboró en los retablos de Genevilla (Navarra), de Elvillar de Álava, de Lapoblación, en uno en Laguardia -desaparecido-. Contrató la conclusión del retablo de Alberite. Recientemente le hemos adjudicado los sepulcros del panteón de Nájera que había contratado el pintor Alonso Gallego; suponemos que mientras estaba al servicio de Juan de Goyaz. Él y su taller participaron en otros retablos del ámbito riojano -Agoncillo, El Busto (Navarra)- y llamado desde Zaragoza talló personalmente las figuras del trascoro de la seo zaragozana y, con el taller, se encargó del retablo de Vera de Moncayo que procede del monasterio de Veruela ${ }^{74}$. El gran retablo de Alberite, que había comenzado Hans de Bolduque, le abrió las puertas de Logroño y aquí contrató el monumental retablo mayor de Santa María de Palacio. También participó en la hechura de la sillería de Santa María la Redonda que llevaba a cabo Juan de Lorena después de que hubiera intervenido Hans de Bolduque.

En agosto de 1552 Arnao de Bruselas se instaló en Logroño y poco después abrió un espacioso taller por el que pasaron gran parte de los artífices residentes en esta localidad ${ }^{75}$. Desde su instalación en la capital riojana, el estilo de Spierinck -que se había manifestado libremente en los retablos de Elvillar, Genevilla y Alberite- alcanzó su máxima expresión, sin sometimiento a ninguna otra consideración y tras un último y nuevo aprendizaje en Zaragoza cuando el retablo de Palacio estaba parcialmente instalado. El re-

74 Es tan amplia la bibliografía sobre Arnao de Bruselas y tan generales los datos que acabamos de apuntar que no ofrecemos aquí bibliografía. La hemos recogido en otras publicaciones previas y daremos cuenta de ellas en una publicación próxima sobre Los escultores flamencos y franceses en La Rioja.

75 El 16 de agosto de 1552 Arnao y su mujer adquirieron una casa situada en la calle Ollerías junto a la muralla de Logroño. El 1 de octubre de 1556 la vendió y pasó a residir en una vivienda de la Puerta Nueva que era propiedad del cabildo de la Redonda. Arnao satisfizo la renta que tenía cargada la casa de 1558 a 1563; SAINZ RIPA, Eliseo, Santa María de la Redonda. De iglesia parroquial a la iglesia concatedral. Siglos XII-XX, Logroño, IER, 1992, pp. 71. RUIZ-NAVARRO PÉREZ, Julián, Arnao de Bruselas. Imaginero renacentista y su obra en el valle medio del Ebro, Logroño, 1981, IER, pp. 14, 69-71; ÁLVAREZ CLAVIJO, Mª Teresa, "El retablo mayor de la Imperial Iglesia de Santa María de Palacio", en FERNÁNDEZ PARDO, Francisco (dir.), La escultura en la Ruta Jacobea: Arnao de Bruselas. Retablo Mayor de la Imperial Iglesia de Palacio (Logroño), Logroño, Diócesis de Calahorra y La Calzada-Logroño, 2005, p. 259. Sobre el taller, BARRÓN GARCÍA, Aurelio Á., “Juan Fernández..., pp. 35-58. 


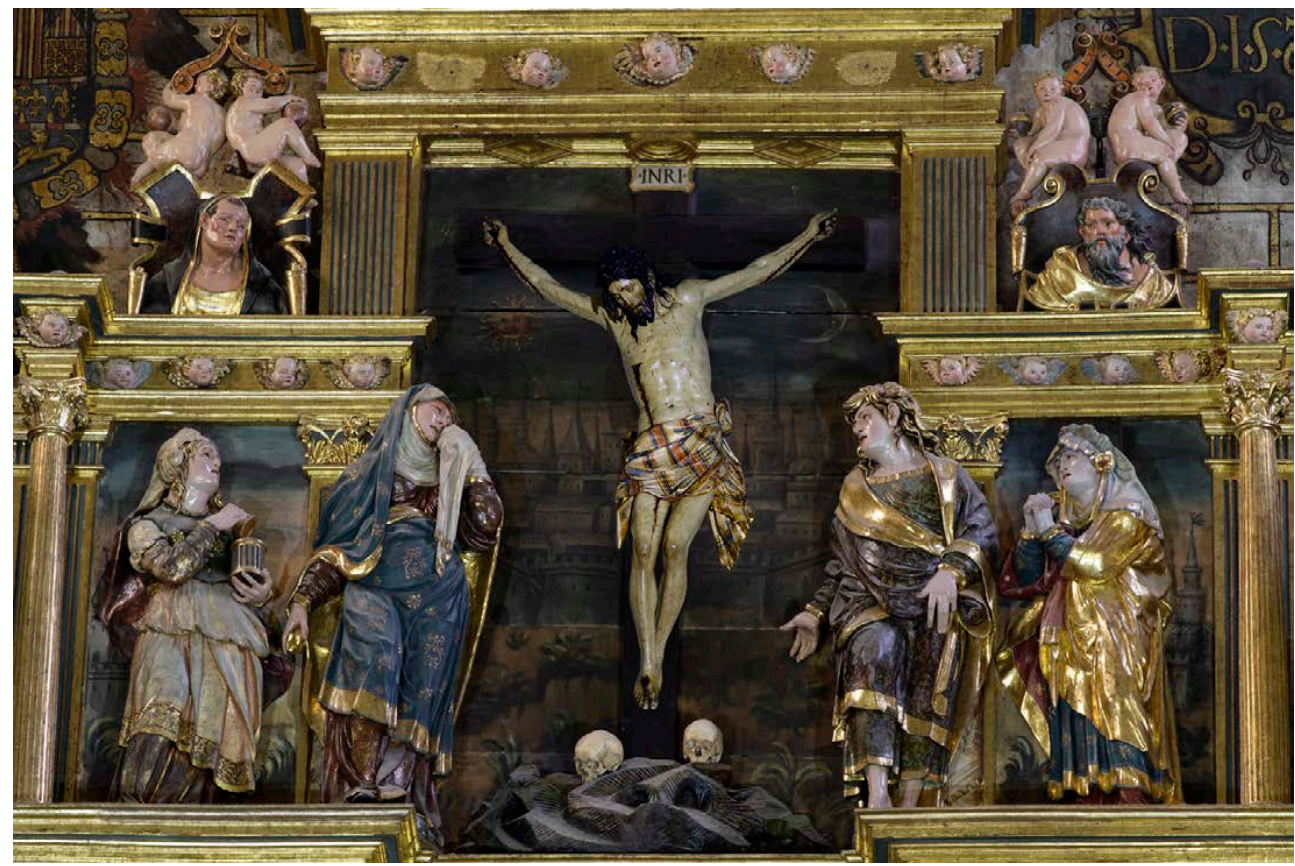

Fig. 13. Retablo mayor, detalle del ático. Arnao Spierinck. 1558-1561. Santa María de Palacio, Logroño. La figura original de Cristo, insertada con herramientas digitales

sultado es soberbio y plenamente renacentista, tanto que pasó desapercibido al experto ojo de Weise ${ }^{76}$.

El retablo mayor de Santa María de Palacio lo había comprometido inicialmente, en 1546 o 1547, Pedro de Bustamante, calificado como imaginario, aunque debía ser únicamente pintor y policromador ${ }^{77}$. El 6 de noviembre de 1546, junto con el pintor Juan de Rojas, apadrinó en la iglesia de Santiago de Logroño a Jerónimo, hijo del escultor Juan de Beaugrant ${ }^{78}$ sin que se sepa si, en ese momento, estaba asociado a la empresa del retablo de Palacio. En

76 WEISE, Georg, Spanische Plastik aus sieben Jahrhunderten, Reutlingen, Gryphius, 1927, II Text, pp. 146-149. Al comentar la escultura de Palacio y la sillería de la Redonda, Weise la comparó con la obra de Berruguete. Más adelante supo de la intervención de Arnao en el retablo de Alberite y no se decidió a relacionarlo con la obra de la sillería de la Redonda y la del retablo de Palacio; WEISE, Georg, Die Plastik der Renaissance..., 1957, pp. 67-69.

77 Pedro de Bustamante se quedó con el contrato del retablo al ofrecer hacerle por cien ducados menos que cualquier otra oferta que se presentara, con tal de encargarse personalmente de la policromía. La documentación sobre el retablo, los pagos a los artífices, los diversos contratos...; RUIZ-NAVARRO PÉREZ, Julián, Arnao de Bruselas..., pp. 22-24 y 55-63; ÁLVAREZ CLAVIJO, Ma Teresa, Las artes en la iglesia..., pp. 154-174 y 218-224.

78 BARRIO LOZA, José Ángel, Los Beaugrant en el contexto de la escultura manierista vasca, Bilbao, Museo de Bellas Artes, 1984, p. 139, doc. 22. 
cualquier caso, las obras parece que se retrasaron y en 1549 -año en el que los parroquianos comenzaron la construcción de la torre de la iglesia- Bustamante cedió el retablo a Juan de Goyaz y únicamente se quedó con la policromía para, finalmente, no realizarla tampoco. Por su parte, Goyaz consta como fallecido en mayo de $1552^{79}$ por lo que la obra del retablo se contrató de nuevo con Arnao de Bruselas y Juan de Rojas. Comenzaron a recibir pagos en $1553^{80}$ y utilizaron la traza existente y lo construido por Goyaz que alcanzó 66336 maravedís -seguramente con la colaboración de Spierinck desde el comienzo de las obras ${ }^{81}$-. Con posterioridad consta que se hicieron mejoras en el retablo una vez estuvo bajo la dirección de Spierinck, pero la original arquitectura del retablo ha de corresponder a Goyaz. Además, es posible que, desde el comienzo de la obra, Goyaz contara con Arnao para la escultura. En mayo de 1552 el entallador Juan de Mordán y el cantero Juan de Landara tasaron la torre de la iglesia de Palacio que había realizado Juan de Acha ${ }^{82}$. Parece seguro que Landara actuó con nombramiento del cantero ${ }^{83}$, de modo que Mordán habría sido propuesto por el cabildo y los mayordomos. La noticia tiene interés pues es muy probable que los canónigos lo conocieran porque trabajaba para Goyaz en el retablo -lo habitual era que se propusiera a un cantero como tasador, a menos que se tuviera confianza en otro artista-. En adelante, todo apunta a que ingresó y se mantuvo siempre en el taller de Spierinck o asociado con él. (Fig. 13)

La construcción del retablo sufrió altibajos. Tras la definitiva contratación se adelantó lo suficiente como para comenzar a asentarlo y trasladar el viejo retablo a la capilla de Nuestra Señora la Antigua. El 24 de noviembre

79 MOYA VALGAÑÓN, José Gabriel, Arquitectura religiosa del siglo XVI en La Rioja Alta, Logroño, IER, 1980, t. II, p, 31; el 3 de mayo de 1552 Juan Ochoa de Arranotegui otorgó poder para pleitos con los herederos de Juan de Goyaz, difunto, y con el concejo y curas de Castrillo y Payueta. Se menciona a Martín de Zaldegui, imaginario habitante en Logroño que podría haber colaborado con Goyaz en la portada de Viana y/o en el retablo de Santa María de Palacio.

80 El primer pago data de enero de 1553: "15 000 maravedis que dio a Juan de Rojas e Arnao de Bruselas para lo del retablo en octubre de 1552, digo en enero de 1553 por libranza"; RUIZ-NAVARRO PÉREZ, Julián, Arnao de Bruselas..., p. 56.

81 Goyaz había recibido 63414 maravedís y otra parte -3000 maravedís- la cobraron Arnao y Juan de Rojas con carta de pago de los herederos de Goyaz fechada el 25 de febrero de 1555; RUIZ-NAVARRO PÉREZ, Julián, Arnao de Bruselas..., pp. 55-56; ÁLVAREZ CLAVIJO, Maㅡ Teresa, Las artes en la iglesia..., pp. 154-155 y 222, doc. 20.

82 ÁLVAREZ CLAVIJO, Maㅡ Teresa, Las artes en la iglesia..., p. 78; ÁLVAREZ CLAVIJO, Maㅗ Teresa, Logroño en el siglo XVI: arquitectura y urbanismo, Logroño, IER, 2003, t. II, pp. 308-310.

83 Pedro de Acha citó en su testamento de 2 de junio de 1552 a Juan de Landara o Langara como criado suyo, de modo que era un cantero de la órbita de los Acha; AHPLR, Lope de Villoslada, prot. 478, f. 321v; MOYA VALGAÑÓN, José Gabriel, Arquitectura religiosa..., T. II, pp. 120-122. También, BARRÓN GARCÍA, Aurelio Á., "La obra del arquitecto tardogótico Juan de Acha", Santander. Estudios de Patrimonio, 1 (2018), p. 90. 
de 1554 el visitador episcopal reconoció que se había "començado asentar el retablo en el altar mayor" ${ }^{\prime 84}$. Mientras se levantaba, la construcción sufrió un parón y el libro de fábrica no registró nuevas entregas al artista hasta 1558, si se exceptúa que en 1555 se aprovechó para liquidar lo que quedaba pendiente por satisfacer a los herederos de Juan de Goyaz.

Hemos apuntado que probablemente Arnao contó con Juan de Mordán y creemos reconocer su mano en el retablo si bien el sistema de trabajo imperante en el taller, que había aprendido al servicio de Forment, dificulta la identificación de manos porque, a nuestro parecer, el maestro acababa las obras y los oficiales empleaban diversos sistemas de traslado de modelos a la madera. Otros oficiales ${ }^{85}$ de Spierinck fueron Agustín Pérez -se desconoce su estilo y su especialidad, y posiblemente lo sirvió también como administrador-, Simeón de Cambray -que, según declaración propia, fue oficial de Arnao durante más de cuatro años, de 1552 a 1556 aproximadamente- y seguramente Juan de Aguirre que confesó que visitaba frecuentemente la casa y taller de Arnao en sus años juveniles aunque su declaración, hecha en 1581, se remite a los años 1560 y siguientes, es decir, a la segunda estancia de Spierinck en Logroño ${ }^{86}$. Del 4 de abril de 1555 data el único contrato de formación de un aprendiz suscrito por Arnao. Entonces, Hernando de Lubiano, huérfano de Juan de Lubiano, solicitó que lo adjudicaran un tutor para poderse asentar con el bruselense y aprender el oficio de imaginero ${ }^{87}$. Criado Mainar ha apuntado que tal vez se corresponda con uno de los testigos presentes en 1558 en la carta de prórroga que, para formalizar el examen de capacitación de Arnao para obrar en Zaragoza, extendió la cofradía de los escultores zaragozanos ${ }^{88}$.

En los miguelangelescos profetas del sotabanco encontramos toda la fuerza expresiva del escultor. A la vez, anticipan la obra de Juan Fernández de Vallejo que adquirió el taller del brabanzón después de andar por Castilla,

84 ÁlVAREZ CLAVIJO, Ma Teresa, Las artes en la iglesia..., pp. 155 y 219, doc. 14. También, ÁLVAREZ CLAVIJO, Ma Teresa, “El retablo mayor..., pp. 249-302.

85 Se ha documentado en la iglesia de Palacio la presencia del imaginero Francisco Gracia en septiembre de 1555. En esta fecha apadrinó, junto con Remón de Brujas, a Juan Arnao, hijo de maestre Arnao de Clabería y de Mencía Jiménez. El 31 de enero de 1557 se bautizó a Petronila, hija de Diego Ruiz, imaginario, y Juana de Villoslada; ÁLVAREZ CLAVIJO, Ma Teresa, “El retablo mayor..., p. 259. Ruiz era un competente escultor que estuvo avecindado en Baños de Río Tobía y Nájera.

86 BARRÓN GARCÍA, Aurelio Á., “Juan Fernández..., pp. 38-39.

87 GOICOECHEA, Cesáreo, "Aspectos de la vida logroñesa en el siglo XVI", Berceo, 64 (1962), p. 273. También, RUIZ-NAVARRO PÉREZ, Julián, Arnao de Bruselas..., p. 69.

88 CRIADO MAINAR, Jesús, “Tradición y renovación en los usos profesionales de los talleres pictóricos zaragozanos del Pleno Renacimiento", Boletín del Museo e Instituto Camón Aznar, 50 (1992), p. 14; CRIADO MAINAR, Jesús, Las artes plásticas..., p. 434. 
sin que se pueda saber si se había formado con Spierinck. Los pequeños relieves del asiento y friso del primer banco son obra de un especialista en figuras pequeñas, tal vez Simeón de Cambray siguiendo dibujos de Arnao unas veces con mejor resultado que otras; en cualquier caso, distintos y superiores a la obra que Cambray emprendió de modo independiente en Los Cameros. A Juan de Mordán, aunque se trate de modelos de Spierinck, adjudicamos los pequeños evangelistas del banco. También, las figuras de San Sebastián, San Bartolomé, el apóstol que hace juego con éste y posiblemente San Juan Bautista. Igualmente puede haber intervenido en las cabezas de algunos profetas del árbol de Jesé.

A la mano de Arnao corresponden Adán y Eva, San Pedro y San Pablo del banco, las figuras de la Cena -ahora modificada al haberse elevado la figura de Cristo y San Juan-, la soberbia imagen de Jesé, el relieve de San Mateo -inspirado en un grabado de Marcantonio Raimondi abierto en 1517 sobre un dibujo de Miguel Ángel que representa a un soldado ajustando los calzones a su coraza-. También ha intervenido ampliamente en las escenas del Lavatorio, la Oración en el Huerto de los olivos, la Presentación, la Adoración de los Reyes y la de los pastores, la Anunciación y la Visitación.

Evidentemente han ayudado otros oficiales y entre ellos destaca uno de gusto clásico, rostros serenos y un tanto estereotipados. No podemos saber de quién se trata, pero apuntamos hacia Felipe de Borgoña. Este oficial se encargó del adorno de buena parte de la mazonería. Compone con mano firme y disposiciones simétricas. El resultado es muy agradable y los niños son especialmente simpáticos y encantadores. Tampoco descartamos que el desconocido oficial sea Pedro Lezcano si, como se ha dicho ${ }^{89}$ le corresponde el retablo de la ermita de Santa María de Velilla en Los Molinos de Ocón. También le ha de pertenecer la imagen sedente de María con el Niño en la parroquia de San Babil de Los Molinos. El rostro clásico, recogido e ensimismado de las figuras femeninas en estas obras del valle de Ocón conjuga bien con lo que se ve en el remate del árbol de Jesé en el retablo de Palacio. Las composiciones de los relieves y la expresividad clásica de los bustos de San Pedro y San Pablo indican que Lezcano se formó en el taller de Spierinck y que, cuando el maestro partió hacia Aragón, inició un camino independiente. Los canónigos de la iglesia de Palacio habían de conocerlo porque, si estamos en lo cierto, había tenido una activa presencia en el taller del bruselense. En 1561, concluido el retablo, lo buscaron en Ocón para que realizara una visura del retablo ${ }^{90}$. También lo vio Sebastián de Rojas. Nicolás de Venero, por

89 MOYA VALGAÑÓN, José Gabriel, Inventario artístico de Logroño y su provincia. Tomo II, Logroño, Servicio Nacional de Información Artística, Arqueológica y Etnológica, 1976, p. 329. 90 RUIZ GALARRETA, José María, Logroño y su provincia, Barcelona, [Rovira], 1962, p. 15. A Lezcano le pagó la parroquia porque "vino a apreciar el retablo nombrado por la iglesia". En 
la iglesia, Andrés de Araoz y Saúl Torres realizaron la tasación definitiva en 1563; Pedro de Bustamante intervino seguramente para valorar la policromía realizada hasta el momento ${ }^{91}$.

En 1558, ya retornado de su estancia aragonesa, volvieron a apuntarse pagos por el retablo de Palacio "64 ducados, despues que vino a entender en el retablo por agosto" ${ }^{\prime 92}$. En adelante talló, casi exclusivamente de su mano, las figuras del ático y remate. Sin la supervisión que Jerónimo Vallejo había ejercido en las obras de Veruela y Zaragoza, dotó a las figuras de un nervio más acentuado, pero mantuvo lo aprendido en el trascoro zaragozano: para el Calvario recurrió al modelo recién creado en Zaragoza. De la misma calidad y nobleza son las imágenes de María Magdalena y la tercera María -María Salomé o María Cleofás-, Santiago, San Jerónimo y Dios Padre. Sin embargo, la Fe y la Caridad, son trasuntos de Santa Columba en Angostina.

Concluido el retablo de Palacio, hubo pleito por el valor del retablo y el cobro de lo adeudado. Para demorar el pago y rebajarlo, la parte de la iglesia adujo que no se habían cumplido los plazos. Por orden del provisor del obispado -el licenciado Sepúlveda- se volvió a tasar el retablo el 17 de marzo de 1563 con la intervención de Andrés de Araoz, vecino de Vitoria, Nicolás de Venero, vecino de Burgos, y Saúl Torres ${ }^{93}$.

El escultor reclamó el abono del precio de tasación al ritmo acordado. Ganó una primera sentencia del provisor que ordenó pagar según los plazos establecidos en el contrato.

Para evitar otras diferencias entre las partes, el 30 de abril de 1563 los diputados elegidos por la iglesia llegaron a un acuerdo con Arnao como principal, y con el pintor Juan de Rojas como su fiador. Previamente habían averiguado las cuentas de todo el gasto del

"retablo y obra que había hecho maestre Arnao e todos los otros oficiales que lo abian hecho e labrado de todas las mexoras e de todo lo que mas todos los otros oficiales abian hecho y en el podian e pudieran pedir en qualquier manera, abian allado quitado e aberiguado e fenesçido se le restaban debiendo, de resto de todo el dicho retablo e obra y madera y echura y mexoras, seteçientos e sesenta y ocho ducados".

otra partida se anotaron "quatro reales de la caballería con la cosa que fueron a Ocón por el"; RUIZ-NAVARRO PÉREZ, Julián, Arnao de Bruselas..., p. 57.

91 ADZ, Apelaciones, C. 210.8; RUIZ-NAVARRO PÉREZ, Julián, Arnao de Bruselas..., 1981, p. 57; ÁLVAREZ CLAVIJO, Ma Teresa, Las artes en la iglesia..., pp. 155 y 222.

92 RUIZ-NAVARRO PÉREZ, Julián, Arnao de Bruselas..., p. 56.

93 Sin precisar la fecha, se había dado noticia de la intervención de Araoz y Venero; RUIZ-NAVARRO PÉREZ, Julián, Arnao de Bruselas..., p. 22; ÁLVAREZ CLAVIJO, Maㅡ Teresa, Las artes en la iglesia..., p. 155. 
Esta cantidad acordaron pagarla con 200 ducados el día de San Miguel -de septiembre-, otros 200 el mismo día del año 1564 y el resto -368 ducados- en la misma fiesta de $1565^{94}$.

En el acuerdo, Spierinck y Rojas se obligaron a que ni ellos ni ningún otro artífice interviniente en el retablo demandaría cantidad alguna: ni de la madera, ni de la talla, ni de la obra del banco, ni de las mejoras hechas en lo alto ni en lo bajo con respecto al contrato, ni de asentar los andamios. Añadieron que saldrían a la defensa de la iglesia si Pedro de Bustamante reclamaba, como había pedido, unos 250 ducados por ciertas imágenes e historias hechas en el retablo y en él colocadas y asentadas. Podemos deducir que los artistas abonarían al pintor Bustamante lo reclamado o que, posiblemente, lo obrado por él lo habían realizado en realidad ellos mismos y la petición de Bustamante, en la primera fase del pleito, se había producido con connivencia de Arnao y para reforzar su petición ${ }^{95}$.

A finales de 1564 o principios de 1565 falleció Arnao Spierinck. Pasó la fiesta de San Miguel de 1565 y finalizaron varios años más sin que se abonara todo el capital adeudado. En 1575 Pérez no quedó conforme con el finiquito que le ofrecía la iglesia. Primero requirió a los mayordomos provisto con la memoria de lo adeudado a Spierinck al tiempo de su testamento: 220000 maravedís del retablo mayor ${ }^{96}$. En diciembre de 1574 quedaban por pagar 43000 maravedís. Del resto, la iglesia había pagado 67500 a Juan Alonso de Medrano por la huerta que éste le había vendido a Arnao; también había entregado 105001 maravedís a Agustín Pérez en vino y cereal; más otros 5000 de la compra de un cáliz que el sacerdote Juan Alonso Pérez -hermano de Agustín- había mandado en su propio testamento a la iglesia, y otros 4 ducados de un ornamento con el que se lo enterró.

En marzo de 1575 hizo nuevo requerimiento. Como no prosperó, Agustín acudió al licenciado Ungo de Velasco, provisor y vicario del obispado, que el 13 de abril ordenó secuestrar una cruz grande y unos candeleros de plata de la sacristía de la iglesia para ponerlos en pública subasta y poder pagar los 43000 maravedís debidos. Ese mismo día se hizo un primer pregón y el 18 de abril se voceó un segundo bando dentro de las puertas del palacio episcopal de Logroño para que cualquiera pudiera adquirir unos candeleros grandes de Palacio por los 43000 maravedís que no pagaban.

Tres días después, un procurador de la iglesia compareció ante el provisor y trajo una memoria con las notas de todo lo pagado a Spierinck. In-

94 ADZ, Apelaciones, C. 210.8.

95 ADZ, Apelaciones, C. 210.8. Las noticias que damos en adelante, salvo indicación contraria, proceden de este pleito.

96 El testamento cifró la deuda en 592 ducados que son 222000 maravedís. 


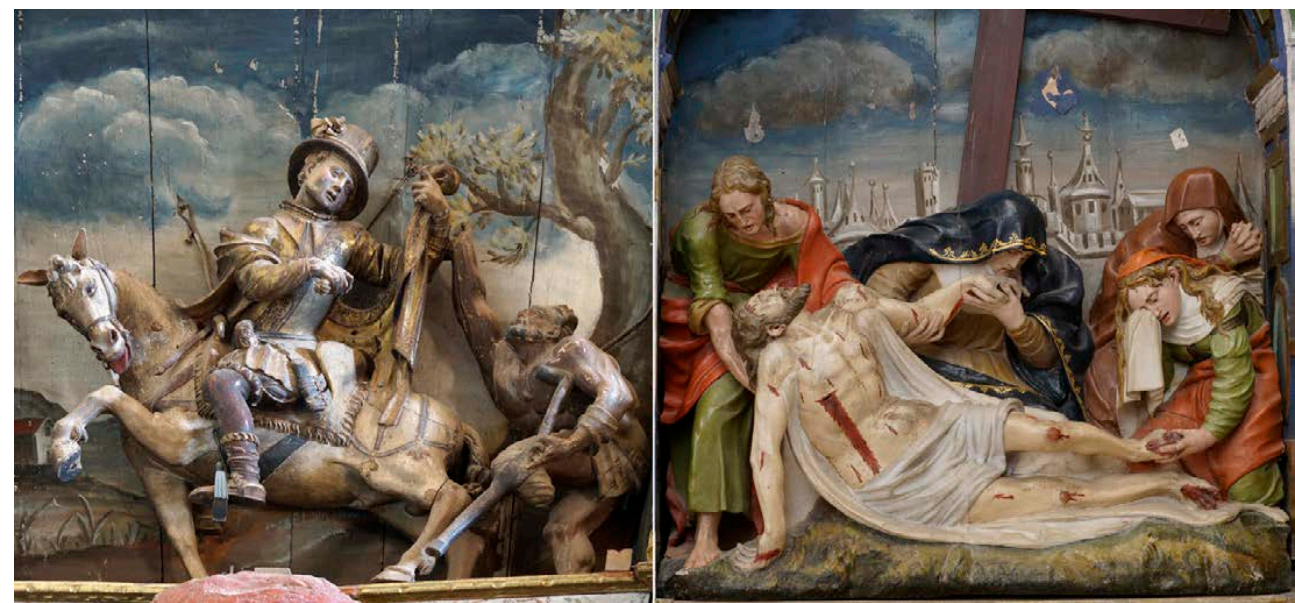

Fig. 14. San Martín y Descendimiento. Arnao Spierinck y taller. H. 1560. Torrecilla sobre Alesanco (La Rioja)

cluyó seis cédulas firmadas por Arnao, con un valor de 71180 maravedís, pagadas desde el 28 de septiembre de 1563 al 20 de octubre de 1564, un día después del testamento y dos antes del codicilo. Apuntaron el pago de 67500 maravedís a quien había vendido al escultor una huerta en Puerta Nueva ${ }^{97}$. Dijeron que Pérez había recibido 187396 maravedís -de 1566 a 1573- en los que incluyeron la mitad de los 14 ducados que el provisor Sepúlveda había ordenado pagar a los tasadores de marzo de 1563, los pagos efectivos en pan y vino, pero también el alquiler de las cubas de vino, el trasiego y aún la vigilancia de mil cántaras de vino, aspectos que valoraron en 25000 maravedís. Además, exigieron que presentara el testamento del bruselense.

Al día siguiente, Agustín Pérez, de 55 años $^{98}$, mostró el testamento de Arnao, negó que se pudieran certificar las cédulas presentadas con firma del bruselense "porque este que declara nunca le bio escribir ny firmar"99. Sin

97 Se transcribieron dos documentos del 18 y 21 de julio de 1564 en los que Arnao compró una huerta en Puerta Nueva a Juan Alonso de Medrano, escribano mayor de la aduana. Para el abono otorgó carta de poder para cobrar 180 ducados en San Miguel del año 1565 de lo adeudado en Palacio. Alonso de Medrano recibió el pago el 16 de noviembre de 1565. Los documentos se trascribieron en el pleito y Arnao hizo mención de todo ello en el testamento.

98 En 1581, en un pleito del escultor Juan Fernández de Vallejo con un vecino del taller, declaró tener unos 60, de modo que había nacido hacia 1520-1521; BARRÓN GARCÍA, Aurelio Á., “Juan Fernández..., p. 40.

99 En una declaración posterior reiteró lo mismo y apuntó que las había escrito el mayordomo: las cédulas le parecían escritas de la letra y mano del mayordomo Francisco Martínez de Enciso "y que las firmas dellas nyega este confesante saber ser de Arnao de Bruselas porque nunca este confesante le bio escribir ni firmar y nyega las firmas de todas las zedulas ser todas escritas de una mano". 
embargo, todas se transcribieron como firmadas por "Bruselas" y se puede sostener que algún rasguño añadía ${ }^{100}$. Pérez también rechazó con éxito que se pudiera imputar el valor de una de las cédulas así como la tasación de Araoz, Venero y Torres porque eran anteriores al acuerdo en el que se estableció la deuda de 768 ducados. Igualmente rechazó los gastos de alquiler y vigilancia de las cubas que pertenecían al cabildo y estaban en Fuenmayor.

La deuda de 43000 maravedís se asemeja sospechosamente a los 41250 maravedís que los mayordomos de la parroquia reclamaron a Pedro de Bustamante en $1564^{101}$. Se los habían entregado cuando en 1546 o 1547, en la primera contratación, ofreció dorar el retablo por 100 ducados menos que cualquier otro postor, pero por las circunstancias ocurridas no había sido el dorador del retablo. Es posible que quisieran repercutir esa pérdida sobre el beneficio de Arnao.

El 7 de julio de 1575 el licenciado Ungo de Velasco, provisor y vicario general del obispado, ordenó que se ejecutara lo sentenciado y se pagara a Agustín Pérez el principal y las costas del pleito. Además, la iglesia no pudo impedir que se ejecutara la sentencia del provisor: el 8 de julio el pregonero Juan Montoya volvió a vocear en público los candeleros secuestrados a la iglesia de Palacio para pagar la deuda a Pérez. Los candeleros realmente se vendieron, ya que consta en las cuentas parroquiales que Hernando de Busto los devolvió a la iglesia una vez que le abonaron, en 1577 y 1578, la cantidad que adeudaban a Cebrián de Bruselas por el retablo mayor ${ }^{102}$.

El mismo día la parte de la iglesia apeló a su santidad y llevó su demanda al arzobispado de Zaragoza. El día 18 acudió también un procurador de Agustín Pérez para confirmar el cobro de los 43400 maravedís - principal y costas- que la fábrica, diputados y mayordomos de Santa María de Palacio adeudaban al heredero de Arnao. Zaragoza refrendó lo sentenciado en Logroño.

\section{3. Otras obras citadas en el testamento}

Spierinck mencionó ${ }^{103}$ algunas obras impagadas o donadas. Un crucifijo que tenía hecho en su casa lo dejó a la cofradía de la Vera Cruz, sita seguramente en la iglesia de Santiago de Logroño en donde pidió ser enterrado, aparte de declararse parroquiano de ella. Ordenó que se pagaran al carpintero Pla-

100 El notario que redactó el testamento dio fe de la misma firma: Bruselas.

101 ÁlVAREZ CLAVIJO, Ma Teresa, Las artes en la iglesia..., p. 223, doc. 21.

102 RUIZ-NAVARRO PÉREZ, Julián, Arnao de Bruselas..., p 23; ÁLVAREZ CLAVIJO, Mํㅡㄹ Teresa, Las artes en la iglesia..., Logroño, IER, 1995, p. 155.

103 Véase el segundo documento del apéndice. 
sencia 5000 maravedís como abono final por todo lo realizado en "la fragua de my casa". En julio de 1564 había adquirido una huerta en Puerta Nueva, donde tenía el taller, y es probable que hiciera reformas en la casa anexa.

Había hecho la mitad del retablo mayor de Nalda y aún le adeudaban 107000 maravedís. Lo había labrado mientras perduraba la asociación con Andrés de Araoz, en torno a 1550. Sufrió un lamentable incendio en el siglo XX y casi todo lo conservado en el actual retablo mayor salió del taller de Araoz $^{104}$. Si acaso en la Última Cena ha podido intervenir algún oficial del brabanzón y, con mayor probabilidad, en la figura de San Miguel. El Museo Marés de Barcelona guarda varias figuras exentas provenientes de Nalda. Tres de ellas son fruto del taller de Arnao: San Roque, San Agustín y San $\operatorname{Marcos}^{105}$. La parroquia posee otra figura de San Roque procedente de una ermita de esta localidad. Es del inconfundible estilo de Hans de Bolduque ${ }^{106}$.

La iglesia y la cofradía de San Martín de Torrecilla sobre Alesanco tenía una deuda de 125 ducados por un retablo hecho para la cofradía de San Martín. Spierinck disfrutaba de una economía tan desahogada que pudo firmar un acuerdo para que pagaran únicamente 6 ducados al año: de 1564 a 1585 . Con ese precio y condiciones se entiende que interviniera su taller. En un retablo posterior del lado del evangelio se conserva el grupo principal con el santo a caballo compartiendo su capa con un mendigo. En el lado contrario se ubica otro retablo del siglo XVII con relieves del Descendimiento y la Oración en el Huerto, son de Spierinck y de mejor calidad ${ }^{107}$. Además, la iglesia del lugar posee dos figuras exentas de San Roque y San Sebastián que también salieron del taller del bruselense. Es posible que todas las piezas formaran parte del comienzo de un retablo con banco, dos entrecalles, tabernáculo no conservado, y comienzo del primer cuerpo con la caja de la figura titular. Así se puede explicar que la parroquia fuera responsable de parte de la deuda. (Fig. 14)

En colaboración con el pintor Juan de Rojas hizo -o mejor su taller- un retablo en la ermita de Tómalos de Torrecilla de Cameros. Algunas tablas de

104 De la misma opinión, BARRIO LOZA, José Ángel, Los Beaugrant..., p. 110.

105 MOYA VALGAÑÓN, José Gabriel, Inventario artístico de Logroño y su provincia. Tomo III, Logroño, Servicio Nacional de Información Artística, Arqueológica y Etnológica, 1985, p. 75; RAMÍREZ MARTÍNEZ, José Manuel, "Sant Agustí, Sant Marc y Sant Roc", en Catàleg d'escultura i pintura dels segles XVI, XVII i XVIII. Ėpoca del Renaixement i el barroc. Fons del Museu Frederic Marès/3, Barcelona, Ajuntament de Barcelona, Direcció de Serveis Editorials, 1996, pp. 201-202; RAMÍREZ MARTÍNEZ, José Manuel, La evolución del retablo en La Rioja. Retablos mayores, Logroño, 2009, pp. 460-461.

106 MOYA VALGAÑÓN, José Gabriel, Inventario artístico... Tomo III, p. 76.

107 MOYA VALGAÑÓN, José Gabriel, Inventario artístico de Logroño y su provincia. Tomo IV, Logroño, IER, 2017, p. 206; con anterioridad a conocerse el vínculo documental, Moya adjudicó los relieves a Arnao, no así el bulto de San Martín a caballo. 


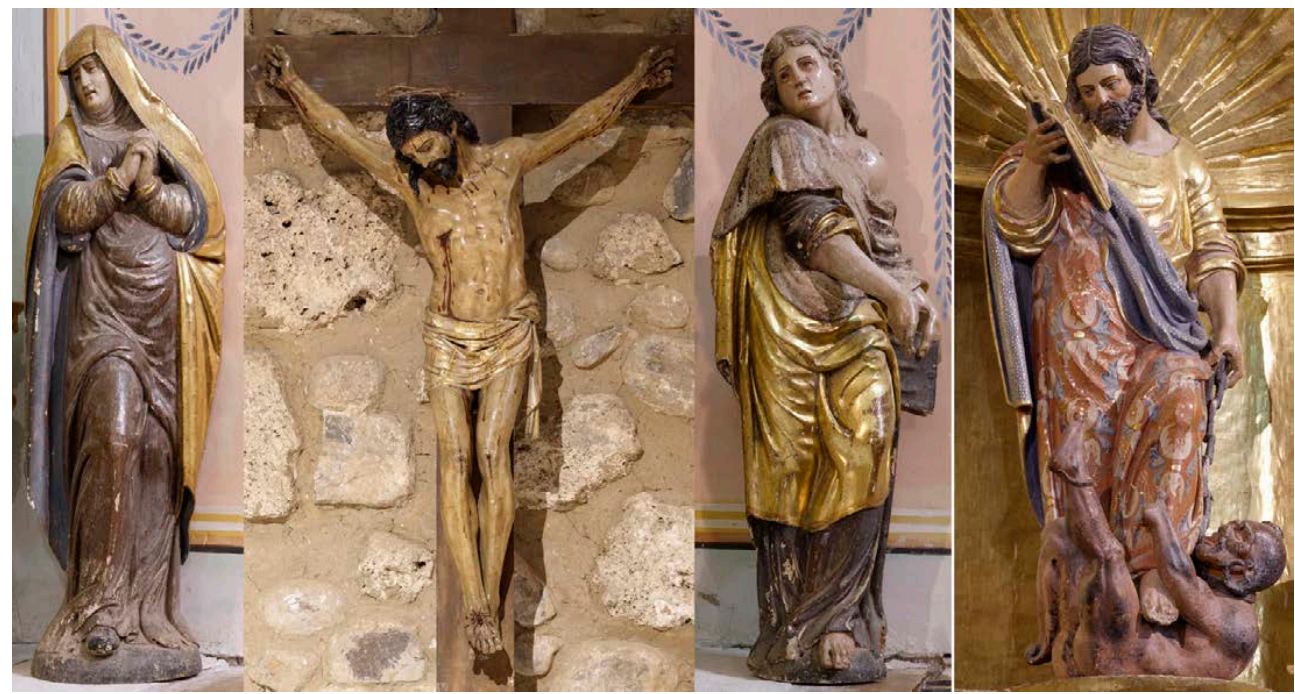

Fig. 15. Figuras del Calvario y San Bartolomé. Taller de Arnao Spierinck. H. 1560. Ermita de Tómalos, Torrecilla de Cameros (La Rioja)

ese retablo se insertan en el actual: corresponden completamente al taller las escenas de relieve y la Asunción. La figura de San Blas es sólo correcta y de cierto mérito la de San Bartolomé. Mayor intervención de Arnao se aprecia en las figuras del Calvario, hoy en otro retablo lateral. Las figuras de San Juan y de María son deudoras del maravilloso Calvario del trascoro de la seo de Zaragoza. Por tanto, la obra se debe datar en los últimos años del artista. El retablo lo había contratado Juan de Rojas -del que se conservan las tablas del banco que permiten identificar su estilo- que traspasó 50 ducados al escultor, sin duda que para compensar su colaboración. Moya Valgañón vincula estas imágenes y relieves con el estilo de Simeón de Cambray ${ }^{108}$. Para los relieves parece evidente y hemos visto que había trabajado en el taller de Spierinck. Sin embargo, las imágenes de bulto nos parecen de mejor calidad que el resto de la producción conocida de Simeón. A Juan de Rojas, que había estado junto a él desde la contratación del retablo de Palacio, perdonó los 400 reales que lo adeudaba. (Fig. 15)

Como se sabía, dejó iniciada la obra del retablo de Aldeanueva de Ebro y en el testamento pidió cobrar "lo que fuere tasado la hobra que tengo echa del retablo conforme a la escriptura". Lo concluyó Juan Fernández de Vallejo, nuevo propietario del taller situado en Puerta Nueva de Logroño ${ }^{109}$. Es la primera obra romanista de Juan Fernández de Vallejo como autor indepen-

108 MOYA VALGAÑÓN, José Gabriel, Inventario artístico... Tomo IV, pp. 202-203.

109 BARRÓN GARCÍA, Aurelio Á., “Juan Fernández..., pp. 35-58. 
diente y director del primer gran taller encabezado por un artista local. Fernández de Vallejo y Pedro Arbulo pusieron fin al protagonismo que habían tenido los escultores extranjeros en las décadas anteriores.

\section{Apéndice documental}

1564, octubre, 22

Logroño

Arnao de Bruselas, estando enfermo, otorga codicilo final en el que nombra a Agustín Pérez tutor y curador de su hijo Cebrián de Bruselas.

Archivo Histórico Provincial de La Rioja, Bernardino Rodríguez, prot. 503, f. 91r.

Citado en, RAMÍREZ MARTÍNEZ, José Manuel, Guía histórico-artística, Logroño, Logroño, Editorial Ochoa, 1994, p. 174, nota 11.

Publicado en, RAMÍREZ MARTÍNEZ, José Manuel, La evolución del retablo en La Rioja. Retablos mayores, Logroño, Obispado de Calahorra, La Calzada y Logroño, 2009, p. 19 del CD, doc. 1.

En la çibdad de Logroño a veynte e dos dias del mes de otubre año del señor de myll e quynientos e sesenta e quatro años en presençia de mi el escribano e testigos paresçio presente maestre Arno de Bruselas vecino desta çibdad [tachado: e dijo] estando enfermo en la cama en lo que paresçia en su buen juizio y entendimyento dixo quel hizo y otorgo su testamento ante Rodrigo de Abeçia escribano del numero desta çibdad al qual se refiere por hende [tachado: quedando en su fuerza e bigor el dicho su testamento y todo en el qontenido] declaraba e declaro que por quanto en el dicho su testamento dexaba por sus cabeçaleros a Maryana su muger e a Juan Ximenez de Cabredo vecinos desta çibdad quel en la mejor forma e manera que podia rebocaba e reboco la dicha cabeçaleria del dicho Juan Ximenez que no quyere que lo sea e en lugar del dicho Juan Ximenez nonbro por su cabezalero juntamente con la dicha Mariana su muger a Agustin Perez vecino desta çibdad al qual dio poder en forma para lo ser segun que en el dicho su testamento lo tenya dado al dicho Juan Ximenez de [Tachado: nçisso] Cabredo.

Yten dixo y declaro que por quanto en el dicho su testamento dexa y nonbra por tutor e curador de Çebrian de Bruselas su hijo menor de hedad a la dicha Mariana su muger, que no quyere que lo sea y en quanto a esta clausula reboca el dicho testamento y nonbraba e nonbro por tutor e curador de la persona e bienes del dicho Çebrian de Bruselas su hijo a Agustin Perez vecino desta çibdad al qual dio poder cunplido para lo ser e para poder cobrar todos e qualesquyer vienes al dicho menor pertenescientes y con lo susodicho mandaba e mando que lo qontenido en su testamento y en este codecillo se cunpla a guarde e aya efetto, quedando el dicho su testamento en todo lo demas en su fuerça e bigor no lo alterando ny mudando ny rebocando mas de en lo de suso, y dello otorgo esta carta de codeçillo y lo en ella qontenido. Testigos Tomas de Montoya e Juan Desquybes e Juan de Birbiesca vecinos de la dicha çibdad de Logroño [Tachado: y el dicho otorgante] y los testigos que 
supieron escrivir lo firmaron de sus nonbres y el dicho otorgante no pudo firmar por no poder al qual yo el escribano doy fee conozco. Va tachado, e dixo, quedando en su fuerça e bigor el dicho su testamento y todo lo qontenido, nçiso, y el dicho otorgante.

[Firmado: Tomas de Montoya. Juan de Birbiesca.]

Passo ante my, Bernardino Rodriguez.

1575, mayo, 6

Logroño

Agustín Pérez, tutor y curador de Cebrián de Bruselas, muestra el testamento que Arnao de Bruselas otorgó estando enfermo el 19 de octubre de 1564 ante el escribano Rodrigo de Abecia.

Archivo Diocesano de Zaragoza, Apelaciones, C. 210.8.

In dey nomine amen. Sepan quantos esta carta de testamento y ultima e postrera boluntad bieren como yo Arnao de Bruselas, escultor veçino de esta çiudad de Logroño, estando en / fermo en la cama que Dios nuestro señor fue serbido de me dar pero en my buen juiçio seso y entendimyento natural y creyendo como creo en la Santisima Trenydad, padre e hijo y espiritu santo, que son tres personas y un solo Dios verdadero que bibe y reina por siempre sin fin, e tenyendo como tengo por my señora y abogada a la birgen Sancta Maria madre de Dios nuestra señora a la qual suplico ser rogadora e ynterzesora con su hijo preçioso que me quiera llebar a su sancta gloria amen por hende hago e otorgo my testamento en la forma y manera siguiente:

Primeramente encomyendo my anyma a Dios nuestro señor que la crio e redimyo por su preçiosa sangre que la quiera perdonar y llebar a su sancta gloria y el cuerpo a la tierra donde fue formado.

Yten mando que si la boluntad / de Dios nuestro señor fuere serbida de me llebar de esta presente bida que my cuerpo sea sepultado en la yglesia de señor Sanctiago desta dicha çiudad donde soy perrochiano.

Yten mando que el dia de my enterramyento se me diga una mysa cantada con sus responsos y se lleben quatro çirios y dos belas para el altar del Sanctisimo sacramento y dos para my sepoltura y ansimesmo los dos dias siguientes de la mysma horden y manera.

Yten mando que se me llebe durante el año de my enterramyento my añal y se de por el doze anegas de trigo y un ducado por la hoblaçion con un çirio y un andeballa que arda a mysa e a besperas todo el año de my falleçimyento y baya sobre mi sepultura Marina my esposa y muger y mando que se le de por su trabajo quinyentos reales.

Yten mando que se haga / my cabo de año segun y como los tres dias de my enterramyento y se pague por todo ello lo ques costumbre.

Yten mando un cruzifijo a la confradia de la bera cruz que es el que tengo echo en casa porque aconpañe my cuerpo el dia de mi fallescimyento.

Yten mando al ospital de la mysericordia seis ducados.

Yten mando a los nyños de la dotrina por que aconpañen my cuerpo el dia de 
mi fallesçimyento seis ducados ya a cada uno un palmo de zera para que bayan en my enterramyento.

Yten mando que se me digan dos mysas rezadas en el altar de san Sebastian de la Madre de Dios y otras dos en el altar y capilla de Diego Diaz Nabarro de sant Francisco.

Yten mando se me digan çient mysas rezadas en la yglesia de señor Sanctiago por my anima y de my muger y en / cargados y se de por ellas lo acostumbrado.

Yten mando a las hordenes acostumbradas cada dos maravedis y con ellos los aparto de mys bienes.

Yten mando que se pague a Plasençia carpintero çinco myl maravedis que le debo de todas quentas dadas y tomadas de la fragua de my casa.

Yten mando se paguen a Abalos sastre las echuras de un sayo y una capa de luto y dos caperuzas.

Yten mando se cobren de la yglesia de Palaçio quinyentos y nobenta y dos ducados y dellos se deben a Juan Alonso çiento y ochenta ducados por razon de la guerta que me bendio como todo pareszera por escripturas y son los dosçientos y doze de plazo pasado asta oy.

Yten mando se cobren de la yglesia de Nalda çiento y siete myl maravedis poco mas o menos que me deben de la / mytad de un retablo que hize y tiene poder Diego Hernandez para los cobrar por doze ducados que le mando.

Yten mando que se cobren de la yglesia de Torreçilla sobre Alesanco y de la confradia de Sant Martin seis ducados en cada un año, los seis del año de sesenta y quatro asta el año de ochenta y çinco que son beinte y un años cada año los dichos seis ducados al dia de Sant Andres como pareszera por escriptura de un retablo que hize para la confradia de Sanct Martin que son çiento y beinte y çinco ducados.

Yten cobren de la yglesia de Aldeanueba lo que fuere tasado la hobra que tengo echa del retablo conforme a la escriptura.

Yten mando se cobren de Santa Maria de Tolonilos de Torresçilla de los Cameros çinquenta ducados poco mas o / menos que me trespaso Rojas en causa propia.

Yten digo que Juan de Rojas me debe asta quatroçientos reales los quales le mando e hago graçia dellos.

Yten mando que se paguen todas las dehudas que paresçiere yo deber con berdad y se cobre lo que pareziere se me debe.

Yten digo que Ysabel my criada y de my muger que sea en gloria nos sirbio un año poco mas o menos y le tengo pagados asta quarenta reales mando que se le cumplan asta seis ducados que son beinte y seis reales los que mando se le paguen.

Yten mando a Juan Flamenco zapatero vezino de Sancto Domyngo los dineros que me deben en Torreçilla de Alesanco que son los dichos çiento y beinte y çinco ducados con tanto que el dicho Juan Flamenco por esta manda que le pago sea hobligado que si my hijo Çibrian muriere / antes que yo o despues menor de hedad aya de ynbiar o abisar a mys dehudos para que bengan a heredar my haçienda y para que sepa los que a de llamar digo que my padre se deçia Tosan Espirin vecino de Bruselas y un hermano que se dize Gil Espirin.

Yten mando a Ana de Leon muger que fue de Hernando de Herze diez ducados por los serbiçios que me a echo. 
Y para cumplir y pagar este my testamento, mandas y legatos en el contenydas dexo por mys cabezaleros a Juan Ximenes de Cabredo e a Mariana my muger vecinos desta dicha çiudad e anbos a dos juntamente y a cada uno yn solidun para que entren y tomen todos mys bienes y de los mexor parados dellos cumplan e paguen este my testamento mandas y legatos en el contenidas y para el remanente dexo por my hunybersal heredero en todos mys bienes restantes a Çibrian my hijo / y si el dicho my hijo fallesçiere menor de hedad de poder testar mando que mys bienes bengan al dicho my padre o hermanos o hermanas que paresçieren y fincaren ser vibos vecinos de Bruselas como se contiene en el capitulo e manda del dicho Juan Flamenco y si faltaren padre o hermanos benga a los parientes mas propincos. $\mathrm{Y}$ dexo por tutor y curador de my hijo a la dicha Marina my muger para que lo sea asta que el dicho Çibrian my hijo sea de hedad de poder testar, e mando que de la dicha tutela e curadoria no se pida quenta a la dicha Marina my muger porque la dexo husufrutaria asta que el dicho Çibrian sea de hedad de tomar su haçienda para la regir y gobernar con tanto que guarde biudez y si se casare dexe la açienda y el menor y de quenta de lo que hubiere gozado y con esto que dicho hes reboco anulo y doy por nynguno otro qualquier testamento o cobde / çilio que yo aya echo, por escrito o por palabra que quiero que no balga salbo este que al presente hago e otorgo ante el presente escrivano e testigos de yuso escritos el qual quiero que balga por my testamento o cobdeçilio o en aquella forma e manera que mexor aya lugar de derecho que fue fecho y otorgado en la çiudad de Logroño a diez y nuebe dias del mes de otubre de myl y quinientos y sesenta y quatro años. Testigos que fueron presentes a lo que dicho hes Tomas de Montoya e Baltasar de Billoslada e Juan de Bitoria pañero, e Pedro de Salas e Juan de Salas vecinos de la dicha çiudad de Logroño y el dicho otorgante lo firmo de su nombre y dos testigos a su ruego y al dicho otorgante doy fee que conozco yo el dicho escribano. Bruselas, Baltasar de Billoslada, Tomas de Montoya. Paso ante my Rodrigo de Abeçia. E yo el dicho Rodrigo de Abezia escrivano publico de su magestad / Real y del numero desta çiudad de Logroño que a lo que dicho hes fuy presente con los dichos testigos e otorgante e de pedimyento de Agustin Perez como cabezalero del dicho Arnao de Bruselas difunto este testamento fize escribir y sacar del horeginal que en my poder queda e fize my signo en testimonyo de verdad Rodrigo de Abeçia.

\section{Bibliografía}

AINAUD, J[oan] y VERRIÉ, F[rederic] P[au],“El retablo del altar mayor del Monasterio de San Cugat del Vallés y su historia", Anales y Boletín de los Museos de Arte de Barcelona, I, 1 (1941), pp. 31-51.

ALBERTI, Leon Batista, Opuscoli morali, Venetia, appresso Francesco Franceschi, Sanese, 1568.

ÁLVAREZ CLAVIJO, Ma Teresa, "El retablo mayor de la Imperial Iglesia de Santa María de Palacio", en FERNÁNDEZ PARDO, Francisco (dir.), La escultura en la Ruta Jacobea: Arnao de Bruselas. Retablo Mayor de la Imperial Iglesia de Palacio (Logroño), Logroño, 2005, pp. 249-302.

ÁLVAREZ CLAVIJO, Mํㅡㄹ Teresa, Las artes en la iglesia Imperial de Santa María de Palacio 
de Logroño (siglos XII al XVII), Logroño, Instituto de Estudios Riojanos (IER), 1995.

ÁLVAREZ CLAVIJO, Maㅡ Teresa, Logroño en el siglo XVI: arquitectura y urbanismo, Logroño, IER, 2003.

BARRIO LOZA, José Ángel, Los Beaugrant en el contexto de la escultura manierista vasca, Bilbao, Museo de Bellas Artes, 1984.

BARRÓN GARCÍA, Aurelio Á., “Juan Fernández de Vallejo y el taller de Arnao de Bruselas", Boletín del Seminario de Estudios de Arte y Arqueología arte, 79 (2013), pp. 35-58.

BARRÓN GARCÍA, Aurelio Á., “La galilea y el panteón real de Nájera: Juan Martínez de Mutio, Alonso Gallego y Arnao de Bruselas", BSAA arte, 84 (2018), pp. 85-124, disponible: https://doi.org/10.24197/bsaaa.84.2018.85-124

BARRÓN GARCÍA, Aurelio Á., "La obra del arquitecto tardogótico Juan de Acha”, Santander. Estudios de Patrimonio, 1 (2018), pp. 69-120, disponible: https://doi. org/10.22429/Euc2018.sep.01.02

BARRÓN GARCÍA, Aurelio Á., "Primeras obras en La Rioja del arquitecto Juan de Rasines, 1469-1542", Boletín del Museo e Instituto Camón Aznar, 110 (2012), pp. 7-84, disponible: https://museogoya.ibercaja.es/boletines/9qbQmdWakOjD.pdf

BARRÓN GARCÍA, Aurelio Á. y RUIZ DE LA CUESTA, Ma Pilar, "El escultor Antonio de Elejalde (1566-1583)", Estudios Mirandeses, 14 (1994), pp. 139-170.

BASSEGODA Y AMIGÓ, Bonaventura, Santa María de la Mar: monografía histórico-artística, Barcelona, Fills de J. Thomas, 1925.

CASTELAIN, Rik, "De familie de Lalaing te Oudenaarde (15 $5^{\text {de }}-16^{\text {de }}$ eeuw)", Handelingen van de Geschied-en Oudheidkundige Kring van Oudenaarde van zijn Kastelnij en van den Lande tusschen Maercke en Ronne, 38 (2001), pp. 15-52, disponible: https://www.dropbox.com/sh/0gj93sne66vu8q1/AAAGxm9RwFdadkLkZ507n3kZa?dl=0\&preview=Handelingen+Oudenaarde+38_2001.pdf

CHAPUIS, Julien, "Escultura alemana: creación y percepción", en Últimos fuegos góticos. Escultura alemana del Bode Museum de Berlín, Valladolid, Ministerio de Educación Cultura y Deporte, Subdirección General de Documentación y Publicaciones, 2016, pp. 16-29.

CHRISTYN, Jean Baptiste, Les Delices des Pais-Bas contenant une description generale des XVII Provinces. Edition nouvelle, divisée en III Volumes, augmentée de plusieurs remarques curieuse, $\mathcal{E}$ enrichie de figures, Brusselle, chez François Foppens, 1711, T. I y II, disponibles: https://opacplus.bsb-muenchen.de/metaopac/search. do?methodToCall=volumeSearch\&dbIdentifier=100\&forward=success\&catKey $=6600019 \&$ \&isPeriodical $=\mathrm{N}$

CRIADO MAINAR, Jesús, Las artes plásticas del Segundo Renacimiento en Aragón. Pintura y escultura 1540-1580, Tarazona, Centro de Estudios Turiasonenses, 1996.

CRIADO MAINAR, Jesús, “Tradición y renovación en los usos profesionales de los talleres pictóricos zaragozanos del Pleno Renacimiento", Boletín del Museo e Instituto Camón Aznar, 50 (1992), pp. 5-84.

DAUSSY, Stéphanie Diane, Sculpter à Amiens en 1500, Rennes, Presses Universitaires de Rennes, 2013.

DE SCHRYVER, Antoine, The Prayer Book of Charles the Bold. A Study of a Flemish Mas- 
terpiece from the Burgundian Court, Los Angeles, The Getty Publications, 2008.

ECHEVERRÍA GOÑI, Pedro Luis y ORBE SIVATTE, Asunción de, "El retablo de San Esteban. Estilo e iconografía", en VV.AA., Renacimiento y Humanismo en Navarra. El retablo de Genevilla, Pamplona, Gobierno de Navarra - Institución Príncipe de Viana, 1991.

FREIXAS I CAMPS, Pere, “Documents per a l'art renaixentista català. L'escultura gironina a la primera meitat del Cinc-cents", Annals de l'Institut d'Estudis Gironins, 28 (1986), pp. 245-279, disponible: https://www.raco.cat/index.php/AnnalsGironins/article/view/53992/64414

GARRIGA RIERA, Joaquim, “Un 'escultor sin obra' del siglo XVI: mestre Joan de Tours, imaginaire, ciutadà de Barcelona”, Homenaje al profesor Martín González, Valladolid, Universidad, Secretariado de Publicaciones, 1995, pp. 343-355.

GOICOECHEA, Cesáreo, "Aspectos de la vida logroñesa en el siglo XVI", Berceo, 64 (1962), pp. 265-294, disponible: https://dialnet.unirioja.es/servlet/articulo?codi$\mathrm{go}=61431$

GUILLOT DE SUDUIRAUT, Sophie, Dévotion et séduction. Sculptures souabes des musées de France vers 1460-1530, Paris, Musée du Louvre - Somogy editions d'art, 2015.

HELMUS, Liesbeth M., Schilderen in opdracht: Noord-Nederlandse contracten voor altaarstukken 1485-1570, Utrecht, Centraal Museum, 2010, disponible: https:// pure.uva.nl/ws/files/744423/71745_thesis.pdf

HERNANSANZ, Ángel, MIÑANA, María Luisa., SARRIÁ, Fernando, SERRANO, Raquel y CALVO, Rosalía, "Juan de Moreto y Martín García: obras de colaboración (1530-1541)”, Seminario de Arte Aragonés, $42-43$ (1990), pp. 351-388.

JARDÍ ANGUERA, Montserrat, Mestres entalladors a Barcelona durant la segona meitat del segle XV i primer quart del segle XVI: de la tradició germánica a la producció local, Barcelona, Universidad de Barcelona, Tesis doctoral, 2006, disponible: http:// diposit.ub.edu/dspace/bitstream/2445/35592/4/03.MJA_CAP_3.pdf

KREN, Thomas, Illuminated Manuscripts from Belgium and the Netherlands in the J. Paul Getty Museum, Los Angeles, Getty Publications, 2010.

LIPINSKA, Aleksandra, Moving Sculptures: Southern Netherlandish Alabasters from the 16th to 17th Centuries in Central and Northern Europe, Leiden/Boston, Brill, 2014.

MADURELL MARIMÓN, José Ma ${ }^{\text {a }}$ "Los maestros de la escultura renaciente en Cataluña. Martín Díez de Liatzasolo", Anales y Boletín de los Museos de Arte de Barcelona, III, 1 (1945), pp. 7-62, disponible: https://ddd.uab.cat/pub/anabolmus/ anabolmus_a1945v3n1.pdf

MADURELL MARIMÓN, José Ma , “Escultores renacentistas en Cataluña”, Anales y Boletín de los Museos de Arte de Barcelona, V, 3-4 (1947), pp. 205-339, disponible: https://ddd.uab.cat/pub/anabolmus/anabolmus_a1947v5n3-4.pdf

MADURELL MARIMÓN, José Ma , “Pedro Nunyes y Enrique Fernandes, pintores de retablos. (Notas para la historia de la pintura catalana de la primera mitad del siglo XVI)", Anales y Boletín de los Museos de Arte de Barcelona, I, 3 (1943), pp. 1391, disponible: https://ddd.uab.cat/pub/anabolmus/anabolmus_a1943v1n3.pdf

MARCHAL, Edmond, Mémoire sur la sculpture aux Pays-Bas pendant les XVIIe et XVIIIe siècles, Bruxelles, F. Hayez, 1877, disponible: https://books.google.es/books?id=- 
juhOAAAAYAAJ\&printsec=frontcover\&hl=es\&source=gbs_ge_summary_r\&$\mathrm{cad}=0 \# \mathrm{v}=$ onepage $\& \mathrm{q} \& \mathrm{f}=$ false

MORTE GARCÍA, Carmen y AZPILICUETA, Miguel, "Arnaut de Bruselas en el taller del escultor Damián Forment", Boletín del Museo e Instituto Camón Aznar, 35 (1989), pp. 65-68.

MORTE GARCÍA, Carmen, Damián Forment, escultor del Renacimiento, Zaragoza, Caja Inmaculada, 2009.

MOYA VALGAÑÓN, José Gabriel, Arquitectura religiosa del siglo XVI en La Rioja Alta, Logroño, IER, 1980.

MOYA VALGAÑÓN, José Gabriel, Inventario artístico de Logroño y su provincia. Tomo II, Logroño, Servicio Nacional de Información Artística, Arqueológica y Etnológica, 1976.

MOYA VALGAÑÓN, José Gabriel, Inventario artístico de Logroño y su provincia. Tomo III, Logroño, Servicio Nacional de Información Artística, Arqueológica y Etnológica, 1985.

MOYA VALGAÑ́N, José Gabriel, Inventario artístico de Logroño y su provincia. Tomo IV, Logroño, IER, 2017.

MUQUARDT, Charles, Monuments d'architecture et de sculpture en Belgique. Le Brabant et les Flandres, Paris, Delaroche, Pilon et comp., 1857, disponible: https:// www.e-rara.ch/zut/content/titleinfo/14993194

RAEPSAET, Henri, "Un mot sur la statue qui surmonte la tour de la maison de ville d'Audenarde", Annales de la Société royale des beaux-arts et de littérature de Gand, 3 (1848-1850), pp. 170-180, disponible: https://lib.ugent.be/catalog/ ser01:000041274

RAEPSAET, J[an] J[oseph], “Lettre adressée au Secrétaire de la Société royale de Beaux-Arts et de Littérature á Gand", Messager des sciences et des arts, Gand, P. F. Goesin-Verhaeghe, 1823, pp. 344-348, disponible: https://lib.ugent.be/en/ catalog?q=Messager+des+sciences+et+des+arts

RAMAKERS, Bartholomeus Adrianus Maria, Spelen en figuren. Toneelkunst en processiecultuur in Oudenaarde tussen Middeleeuwen en Moderne Tijd, Amsterdam, Amsterdam University Press, 1996, p. 81.

RAMÍREZ MARTÍNEZ, José Manuel, Guía histórico-artística, Logroño, Logroño, Editorial Ochoa, 1994.

RAMÍREZ MARTÍNEZ, José Manuel, La evolución del retablo en La Rioja. Retablos mayores, Logroño, Obispado de Calahorra, La Calzada y Logroño, 2009.

RAMÍREZ MARTÍNEZ, José Manuel, "Sant Agustí, Sant Marc y Sant Roc", en Catàleg d'escultura i pintura dels segles XVI, XVII i XVIII. Època del Renaixement $i$ el barroc. Fons del Museu Frederic Marès/3, Barcelona, Ajuntament de Barcelona, Direcció de Serveis Editorials, 1996, pp. 201-202.

RÍO DE LA HOZ, Isabel del, El escultor Felipe Bigarny (h. 1470-1542), Valladolid, Junta de Castilla y León, 2001.

RUIZ GALARRETA, José María, Logroño y su provincia, Barcelona, [Rovira], 1962.

RUIZ-NAVARRO PÉREZ, Julián, Arnao de Bruselas. Imaginero renacentista y su obra en el valle medio del Ebro, Logroño, IER, 1981.

SAINZ RIPA, Eliseo, Santa María de la Redonda. De iglesia parroquial a la iglesia conca- 
tedral. Siglos XII-XX, Logroño, IER, 1992.

SMEYERS, Maurits, "Het Marianum of Onze-Lieve-Vrouw-in-de-zon: Getuige van een laat-middeleeuwse devotie in de Nederlanden en in Duitsland", Nederlands Kunsthistorisch Jaarboek (NKJ) / Netherlands Yearbook for History of Art, 45 (1994), pp. 270-299.

SOLIS, Virgil, Wappenbüchlein. Zu Ehren Der Römischen Kay. vnd Kü. Mt., auch Bäbstlicher Heyligkeit, sambt anndern der Fürnemsten auslendischen Königreichen, Churfürsten, Fürsten ond gemeinen stennden ... Souil derselben Wappen ... mit Jren namen vnd farben, Nürnberg, Solis, [1555].

VAN CAUWENBERGHE, Edouard-Fr., Lettres sur l'histoire d'Audenarde, Audenarde, F. van Peteghem-Ronsse, [1847], disponible: https://lib.ugent.be/nl/catalog?q=Lettres+sur+1\%E2\%80\%99histoire+d $\%$ E2\%80\%99Audenarde $\% 2 C$

VAN DER AA, A. J., Biographisch woordenboek der Nederlanden. Deel 17. Tweede stuk, Haarlem, J. J. van Brederode, 1874, p. 910, disponible: http://www.dbnl.org/ tekst/aa_001biog21_01/colofon.php_

VAN DER MEERSCH, Désiré Joseph, “Description architectonique de l'hôtel-deville d'Audenarde, considéré comme monument du génie d'Artistes Belges du XVIe siècle", Messager des sciences et des arts, 6 (1829-1830), Gand, P. F. de Goesin-Verhaeghe, pp. 65- 102, disponible: https://lib.ugent.be/en/catalog?q=Messager+des+sciences+et+des+arts

VAN DER STOCK, Jan, "Antwerps beeldhouwwerk: over de praktijk van het merktekenen", en VAN VLIERDEN, C. y SMEYERS, M. (eds.), Merken opmerken. Merk- en meestertekens op kunstwerken in de Zuidelijke Nederlanden en het Prinsbisdom Luik. Typologie en methode, Leuven, Puitgeverij Peeters, 1990, pp. 127-144.

VAN HOECKE, Karl, “De historiciteit achter de stadslegende van 'Hanske de krijger' $\left(15^{\mathrm{de}}-16^{\text {de }}\right.$ eeuw)", Handelingen van de Geschied- en Oudheidkundige Kring van Oudenaarde van zijn Kastelnij en van den Lande tusschen Maercke en Ronne, 56 (2019), pp. 5-56.

VAN KERKHOVEN, Geertrui, "Steenrijk stadhuis Oudenaarde", Openbaar Kunstbezit in Vlaanderen (OKV), 1 (2003), pp. 3-43.

VAN LERBERGHE, Lodewyk y RONSSE, Jozef, "Documenten. Fakende de Bouwing van het Stadhuis te Audenaerde", en Audenaerdsche mengelingen, $3^{\text {de }}$ Deel, Audenaerde, Drukkery van F. van Peteghem-Ronsse, 1848, pp. 307-484, disponible: https://lib.ugent.be/nl/catalog/rug01:001245168?i=0\&q=Audenaerdsche+mengelingen

VAN LERBERGHE, Lodewyk y RONSSE, Jozef, Audenaerdsche mengelingen, $1^{\text {ste }}$ Deel, Audenaerde, Drukkery van Gommar de Vos, 1845, disponible: https://lib.ugent. be/nl/catalog/rug01:001245168?i=0\&q=Audenaerdsche+mengelingen

VAN LERBERGHE, Lodewyk y RONSSE, Jozef, Audenaerdsche mengelingen, $2^{\text {de }}$ Deel, Audenaerde, Drukkery van Gommar de Vos, 1846.

VAN LERBERGHE, Lodewyk y RONSSE, Jozef, Audenaerdsche mengelingen, $4^{\text {de }}$ Deel, Audenaerde, Drukkery van F. van Peteghem-Ronsse, 1850.

VAN LERBERGHE, Lodewyk y RONSSE, Jozef, Audenaerdsche mengelingen, $6^{\text {de }}$ Deel, Audenaerde, Drukkery van F. van Peteghem-Ronsse, 1854.

VAN LERBERGHE, Louis, Het portael der kollegiekamer van het Stadhuis te Audenaerde, 
en Pauwels van der Schelden, Beeldsnyder, Audenaerde, Drukkery van Gommar de Vos, 1842 , disponible: https://lib.ugent.be/nl/catalog?q=Het+portael+der+kollegiekamer+van+het+Stadhuis+te+Audenaerde

VANDAMME, Erik, De polychromie van Gotische houtsculptuur in de Zuidelijke Nederlanden: materialen en technieken, Brussel, Koninklijke Academie voor wetenschappen, letteren en schone kunsten van België, 1982.

VANDER STRAETEN, Edmond, "Épisodes de l'histoire de la sculpture en Flandre d'après des documents inédits. Audenarde et Ypres", Bulletin des Commissions Royales d'Art et d'Archéologie, 31 (1892), pp. 259-290, disponible: http://www. crmsf.be/sites/default/files/book/BCRAA-31.pdf

VANDER STRAETEN, Edmond, "Notes sur quelques peintres et sculpteurs belges, 1414 à 1760", en Messager des sciences historiques des arts de la bibliographie de Belgique, Gand, Imprimerie et Lithographie de L. Hebbelynck, 1856 , disponible: https://lib.ugent.be/en/catalog/bkt01:000357156?i=1\&q=Messager+des+sciences+historiques+des+arts+de+la+bibliographie+de+Belgique

VANDERSTRAETEN, Edmond, "Les maitres de Paul Vanderschelden, auteur du portail de la salle échevinale à Audenarde", Annales de l'Académie d'Archéologie de Belgique, 10 (1855), pp. 393-401 1, disponible: https://archive.org/details/annalesdelacad10acad/page/n421

VANDEVELDE, Marie Josephe, Het Stadsmuseum van Oudenaarde: Kataloog, Gent, Federatie voor Toerisme in Oost-Vlaanderen, 1961.

WEISE, Georg, Die Plastik der Renaissance und des Frühbarock im Nördlichen Spanien. Aragón, Navarra, die Baskischen Provinzen und die Rioja, Tübingen, Hopfer-Verlag, 1957.

WEISE, Georg, Spanische Plastik aus sieben Jahrhunderten, Reutlingen, Gryphius, 1927, $2 \mathrm{t}$.

WOLFF, Martha, The Illustrated Bartsch. 23. German and Netherlandish masters of the fifteenth and sixteenth centuries, New York, Abaris Book, 1985.

YEGUAS I GASSÓ, Joan, “Encàrrecs artístics (1505-1517) derivats del testament de Galceran de Requesens: Barcelona, Montserrat i Palamós", Estudis del Baix Empordá, 34 (2015), pp. 225-255 , disponible: https://dialnet.unirioja.es/servlet/articulo? codigo $=5305781$

YEGUAS I GASSÓ, Joan, L'escultor Damià Forment a Catalunya, Lleida, Universitat de Lleida, 1999.

YEGUAS I GASSÓ, Joan, L'escultura a Catalunya entre 1490 i 1575. De la tradició medieval a la difusió $i$ consolidació de les formes "a la romana", Barcelona, Universitat de Barcelona, 2001.

YEGUAS I GASSÓ, Joan, “Obres al convent de Bellpuig (1507-1535)”, Urtx: revista cultural de l'Urgell, 17 (2004), pp. 127-160 , disponible: https://dialnet.unirioja.es/ servlet/articulo? codigo $=2437965$

YEGUAS I GASSÓ, Joan, "Sobre l'escultor Martí Díez de Liatzasolo (circa 15001583)", Locus Amoenus, 5 (2000-2001), pp. 179-194 , disponible: https://dialnet. unirioja.es/servlet/articulo?codigo $=2803254$ 